Cochrane Database of Systematic Reviews

\title{
Dietary fibre for the primary prevention of cardiovascular disease
} (Review)

Hartley L, May MD, Loveman E, Colquitt JL, Rees K

Hartley L, May MD, Loveman E, Colquitt JL, Rees K.

Dietary fibre for the primary prevention of cardiovascular disease.

Cochrane Database of Systematic Reviews 2016, Issue 1. Art. No.: CD011472.

DOI: 10.1002/14651858.CD011472.pub2.

www.cochranelibrary.com 
TABLE OF CONTENTS

HEADER 1

ABSTRACT

PLAIN LANGUAGE SUMMARY

BACKGROUND

OBJECTIVES

METHODS

Figure 1.

RESULTS

Figure 2.

Figure 3.

Figure 4.

DISCUSSION

AUTHORS' CONCLUSIONS

ACKNOWLEDGEMENTS

REFERENCES

CHARACTERISTICS OF STUDIES

DATA AND ANALYSES

Analysis 1.1. Comparison 1 Fibre versus control, Outcome 1 Total Cholesterol mmol/L change.

Analysis 1.2. Comparison 1 Fibre versus control, Outcome $2 \mathrm{HDL}$ Cholesterol mmol/L change.

Analysis 1.3. Comparison 1 Fibre versus control, Outcome 3 LDL Cholesterol mmol/L change.

Analysis 1.4. Comparison 1 Fibre versus control, Outcome 4 Triglycerides $\mathrm{mmol} / \mathrm{L}$ change.

Analysis 1.5. Comparison 1 Fibre versus control, Outcome 5 Systolic blood pressure (mmHg) change.

Analysis 1.6. Comparison 1 Fibre versus control, Outcome 6 Diastolic blood pressure $(\mathrm{mmHg})$ change.

Analysis 2.1. Comparison 2 Subgroup analyses, Outcome 1 Total cholesterol mmol/L change.

Analysis 2.2. Comparison 2 Subgroup analyses, Outcome $2 \mathrm{HDL}$ Cholesterol mmol/L change.

Analysis 2.3. Comparison 2 Subgroup analyses, Outcome $3 \mathrm{LDL}$ Cholesterol $\mathrm{mmol} / \mathrm{L}$ change.

Analysis 2.4. Comparison 2 Subgroup analyses, Outcome 4 Triglycerides $\mathrm{mmol} / \mathrm{L}$ change.

Analysis 2.5. Comparison 2 Subgroup analyses, Outcome 5 Systolic blood pressure $(\mathrm{mmHg})$ change.

Analysis 2.6. Comparison 2 Subgroup analyses, Outcome 6 Diastolic blood pressure $(\mathrm{mmHg})$ change.

Analysis 2.7. Comparison 2 Subgroup analyses, Outcome 7 Total cholesterol mmol/L change.

Analysis 2.8. Comparison 2 Subgroup analyses, Outcome $8 \mathrm{HDL}$ Cholesterol mmol/L change.

Analysis 2.9. Comparison 2 Subgroup analyses, Outcome 9 LDL Cholesterol $\mathrm{mmol} / \mathrm{L}$ change.

Analysis 2.10. Comparison 2 Subgroup analyses, Outcome 10 Triglycerides mmol/L change.

Analysis 2.11. Comparison 2 Subgroup analyses, Outcome 11 Systolic blood pressure $(\mathrm{mmHg})$ change.

Analysis 2.12. Comparison 2 Subgroup analyses, Outcome 12 Diastolic blood pressure $(\mathrm{mmHg})$ change. APPENDICES

WHAT'S NEW

CONTRIBUTIONS OF AUTHORS

DECLARATIONS OF INTEREST

SOURCES OF SUPPORT

DIFFERENCES BETWEEN PROTOCOL AND REVIEW

INDEX TERMS 
[Intervention Review]

\section{Dietary fibre for the primary prevention of cardiovascular disease}

Louise Hartley ${ }^{1}$, Michael D May², Emma Loveman ${ }^{3}$, Jill L Colquitt ${ }^{3}$, Karen Rees ${ }^{1}$

1Division of Health Sciences, Warwick Medical School, University of Warwick, Coventry, UK. 2Warwick Medical School, University of Warwick, Warwick, UK. ${ }^{3}$ Effective Evidence LLP, Eastleigh, UK

Contact address: Karen Rees, Division of Health Sciences, Warwick Medical School, University of Warwick, Coventry, Warwickshire, CV4 7AL, UK. Karen.Rees@warwick.ac.uk, rees_karen@yahoo.co.uk.

Editorial group: Cochrane Heart Group

Publication status and date: Edited (no change to conclusions), published in Issue 2, 2016.

Citation: Hartley L, May MD, Loveman E, Colquitt JL, Rees K. Dietary fibre for the primary prevention of cardiovascular disease. Cochrane Database of Systematic Reviews 2016, Issue 1. Art. No.: CD011472. DOI: 10.1002/14651858.CD011472.pub2.

Copyright @ 2016 The Cochrane Collaboration. Published by John Wiley \& Sons, Ltd.

\section{A B S T R A C T}

\section{Background}

The prevention of cardiovascular disease (CVD) is a key public health priority. A number of dietary factors have been associated with modifying CVD risk factors. One such factor is dietary fibre which may have a beneficial association with CVD risk factors. There is a need to review the current evidence from randomised controlled trials (RCTs) in this area.

\section{Objectives}

The primary objective of this systematic review was to determine the effectiveness of dietary fibre for the primary prevention of CVD.

\section{Search methods}

We searched the Cochrane Central Register of Controlled Trials (CENTRAL) in The Cochrane Library, Ovid MEDLINE (1946 to January 2015), Ovid EMBASE (1947 to January 2015) and Science Citation Index Expanded (1970 to January 2015) as well as two clinical trial registers in January 2015. We also checked reference lists of relevant articles. No language restrictions were applied.

\section{Selection criteria}

We selected RCTs that assessed the effects of dietary fibre compared with no intervention or a minimal intervention on CVD and related risk factors. Participants included adults who are at risk of CVD or those from the general population.

\section{Data collection and analysis}

Two authors independently selected studies, extracted data and assessed risk of bias; a third author checked any differences. A different author checked analyses.

\section{Main results}

We included 23 RCTs (1513 participants randomised) examining the effect of dietary fibre. The risk of bias was unclear for most studies and studies had small sample sizes. Few studies had an intervention duration of longer than 12 weeks. There was a wide variety of fibre sources used, with little similarity between groups in the choice of intervention.

None of the studies reported on mortality (total or cardiovascular) or cardiovascular events. Results on lipids suggest there is a significant beneficial effect of increased fibre on total cholesterol levels (17 trials (20 comparisons), 1067 participants randomised, mean difference $-0.20 \mathrm{mmol} / \mathrm{L}, 95 \% \mathrm{Cl}-0.34$ to -0.06 ), and LDL cholesterol levels (mean difference $-0.14 \mathrm{mmol} / \mathrm{L}, 95 \% \mathrm{Cl}-0.22$ to -0.06 ) but not on triglyceride levels (mean difference $0.00 \mathrm{mmol} / \mathrm{L}, 95 \% \mathrm{Cl}-0.04$ to 0.05 ), and there was a very small but statistically significant decrease rather than increase in HDL levels with increased fibre intake (mean difference $-0.03 \mathrm{mmol} / \mathrm{L}, 95 \% \mathrm{Cl}-0.06$ to -0.01 ). Fewer studies (10 trials, 661 participants randomised) reported blood pressure outcomes where there is a significant effect of increased fibre consumption on diastolic 
blood pressure (mean difference $-1.77 \mathrm{mmHg}, 95 \% \mathrm{Cl}-2.61$ to -0.92 ) whilst there is a reduction in systolic blood pressure with fibre but this does not reach statistical significance (mean difference $-1.92 \mathrm{mmHg}, 95 \% \mathrm{Cl}-4.02$ to 0.19 ). There did not appear to be any subgroup effects by the nature of the type of intervention (fibre supplements or provision of foods/advice to increase fibre consumption) or the type of fibre (soluble/insoluble) although the number of studies contributing to each subgroup were small. All analyses need to be viewed with caution given the risks of bias observed for total cholesterol and the statistical heterogeneity observed for systolic blood pressure. Adverse events, where reported, appeared to mostly reflect mild to moderate gastrointestinal side-effects and these were generally reported more in the fibre intervention groups than the control groups.

\section{Authors' conclusions}

Studies were short term and therefore did not report on our primary outcomes, CVD clinical events. The pooled analyses for CVD risk factors suggest reductions in total cholesterol and LDL cholesterol with increased fibre intake, and reductions in diastolic blood pressure. There were no obvious effects of subgroup analyses by type of intervention or fibre type but the number of studies included in each of these analyses were small. Risk of bias was unclear in the majority of studies and high for some quality domains so results need to be interpreted cautiously. There is a need for longer term, well-conducted RCTs to determine the effects of fibre type (soluble versus insoluble) and administration (supplements versus foods) on CVD events and risk factors for the primary prevention of CVD.

\section{PLAIN LANGUAGE SUMMARY}

\section{Dietary fibre to prevent cardiovascular disease}

\section{Background}

Cardiovascular diseases (CVD) are a group of conditions affecting the heart and blood vessels. CVD is a global burden and varies between regions, and this variation has been linked in part to dietary factors. Such factors are important because they can be modified to help with CVD prevention and management.This review assessed the effectiveness of increased fibre intake as a supplement or in food stuffs in reducing cardiovascular death, all-cause death, non-fatal endpoints (such as heart attacks, strokes and angina) and CVD risk factors in healthy adults and adults at high risk of CVD.

\section{Study characteristics}

We searched scientific databases for randomised controlled trials (clinical trials where people are allocated at random to one of two or more treatments) looking at the effects of dietary fibre intake in healthy adults or those at high risk of developing CVD. We did not include people who already had CVD (e.g. heart attacks and strokes). The evidence is current to January 2015.

\section{Key results}

Twenty three trials fulfilled our inclusion criteria. All of the trials were short term and so could not examine the effect of fibre intake on CVD events. All of the trials examined the effects of fibre intake on lipid levels (lipids are fat-like substances, including cholesterol found in the blood), blood pressure or both. Pooling the results showed a beneficial reduction in total cholesterol and LDL cholesterol (sometimes called 'bad' cholesterol), and diastolic blood pressure with increasing fibre intake. There were no clear patterns for the type of fibre used (soluble or insoluble fibre) or the way in which fibre was provided (via supplements or food stuffs) but their were few studies in each group so results are uncertain.

\section{Risk of bias of the included studies}

Overall the risk of bias was unclear with few studies judged to be at low risk of bias (so less chance of arriving at the wrong conclusions because of favouritism by the participants or researchers), and for some there was a high risk of bias for some of the quality criteria. The results of this review need to be interpreted cautiously bearing this in mind. There is a need for longer-term well-conducted RCTs to determine the effects of fibre intake on CVD events and to further explore effects by the type of fibre and the way in which increased fibre is provided. 


\section{B A C K G R O U N D}

\section{Description of the condition}

Cardiovascular diseases (CVD) are a group of conditions that affect the heart and blood vessels and include coronary heart disease, cerebrovascular disease, and peripheral arterial disease (WHO 2013). One of the main mechanisms thought to cause CVD is atherosclerosis, where the arteries become clogged by atheromas or plaques (NHS 2012). CVD occurs when the arteries are completely blocked or when blood flow is restricted by a narrowed artery, limiting the amount of blood and oxygen delivered to organs or tissue (British Heart Foundation 2014). Arteries may naturally become harder and narrower with age, although this process may be accelerated by such factors as a sedentary lifestyle, obesity, ethnicity, smoking, high cholesterol, and high blood pressure (NHS 2012). Another cause of CVD is unstable plaque rupturing. It is thought that unstable plaques activate an inflammatory response in the body that causes the structure of atherosclerotic plaque to weaken and rupture, leading to the formation of blood clots (Spagnoli 2007).

CVD is the number-one cause of death and disability (WHO 2013) globally. Around $30 \%$ of total global deaths can be attributed to CVD (WHO 2013), and it is estimated to cause 17 million deaths per year (Bovet 2012). The World Health Organization (WHO) reports that by 2030, CVDs will account for almost 23.3 million deaths per year (WHO 2013). This burden is set to increase as a consequence of ageing populations and increasing levels of sedentary lifestyles and obesity.

One key public health priority in the prevention of CVD is targeting modifiable risk factors. One such risk factor is diet, which plays a major role in the aetiology of many chronic conditions, including CVD. Indeed, there are a number of dietary factors that have been found to be associated with a decrease in CVD risk, such as a low sodium intake (Aburto 2013), a low-carbohydrate diet (Hu 2014), intake of whole grains (Ye 2012), and a high consumption of fruits and vegetables (Begg 2007; Oude 2010). Such factors are important, not only because they have been linked to CVD development, but also because they can be modified. This makes them one of the main targets for interventions aimed at primary prevention and management of CVD.

\section{Description of the intervention}

To date, there is no globally accepted single definition for dietary fibre because of disagreements about which plant-derived substances should be included and how fibre values are derived (Buttriss 2008). In general, dietary fibre refers to the variety of plant substances that are resistant to the action of digestive enzymes (Eastwood 1983). Dietary fibre can be categorised into two main groups: soluble and insoluble. Soluble fibre dissolves in water and delays the emptying of the stomach by forming a gel that slows digestion (Dietitians of Canada 2012). Sources of soluble fibre include bran, flaxseeds, oat cereal, and pears. Insoluble fibre, on the other hand, does not dissolve in water and speeds up the passage of food and waste through the stomach (Dietitians of Canada 2012). Sources of insoluble fibre include brown rice, barley, cabbage, celery, and whole grains. As each type of fibre aids the body in different ways, it is important that a healthy diet incorporates both soluble and insoluble fibre (NHS 2013).
Fibre consumption among the global population is low. For example, in the United Kingdom between 2008 and 2011, average intake of fibre was $12.8 \mathrm{~g}$ per day for women and $14.8 \mathrm{~g}$ per day for men (British Nutrition Foundation 2012) In the United States, the average fibre intake was $15.9 \mathrm{~g}$ per day for 2007 to 2008 (King 2012). Figures are similar in Japan and Malaysia (Nakaji 2002; Ng 1997). Current dietary recommendations for fibre intake range from $18 \mathrm{~g}$ per day (NHS 2013) to 40 g per day (King 2012; WHO 1990).

Little is known about the adverse effects of ingesting fibre over time (Bliss 2011), however, many studies have reported minor adverse events when administering gum arabic or psyllium in various doses to different populations (Jenkins 2002; Vuksan 2008). Indeed, Bliss 2011 found that when receiving fibre supplements, individuals with fecal incontinence experienced flatus, belching, fullness, and bloating.

\section{How the intervention might work}

The exact mechanisms by which dietary fibre reduces CVD risk are not known. However, when exposed to water, soluble fibre forms a gel in the stomach and small intestine that helps slow gastric emptying, hurry small intestine movement, and control nutrient absorption. In doing so, it is thought that soluble fibre reduces the effect of postprandial blood glucose and lipid increases (James 2003; Lunn 2007; Threapleton 2013), both of which are CVD risk factors. Furthermore, both soluble and insoluble fibre are thought to increase gastric distension and have an effect on gut hormones that increases satiety, leading to a lower food intake and, in the long term, weight reduction and improved glucose metabolism (Lattimer 2010; Satija 2012).

Dietary fibre has also been shown to increase the rate of bile acid excretion, which reduces total and low-density lipoprotein (LDL) cholesterol. In addition, once fermented in the colon, dietary fibre produces short-chain fatty acids that inhibit the synthesis of cholesterol (Lattimer 2010; Satija 2012). Finally, dietary fibre may have an impact upon plaque stability by decreasing proinflammatory cytokines known to affect plaque stability (Lattimer 2010).

A recent meta-analysis of prospective cohort studies has shown a reduced risk of total mortality with increased fibre intake (pooled adjusted relative risk of total mortality for the highest category of dietary fibre intake versus the lowest was $0.77(95 \% \mathrm{Cl} 0.74$ to 0.8) (Kim 2014). This has been confirmed in a recent observational cohort analysis of the PREDIMED trial (Buil-Cosiales 2014). A number of observational studies have also shown dietary fibre to have a beneficial association with CVD risk factors (Ascherio 1996; Eshak 2010; Kokubo 2011). One study showed an inverse relationship between dietary fibre and CVD risk in 39,876 female health professionals (Liu 2002), and another study showed that a high consumption of fibre is associated with a lower risk of incident ischaemic CVD in both men and women after a mean follow-up of 13.5 years (Wallström 2012). Further evidence on the beneficial association between dietary fibre and blood pressure and lipid levels can be found from systematic reviews of observational studies. Threapleton 2013 looked at evidence on dietary fibre and CVD risk from prospective cohort studies and found that a low risk of both CVD and coronary heart disease was associated with high dietary fibre intake. 
Experimental studies have also shown dietary fibre to have a beneficial effect on CVD risk factors (Berg 2003; Saltzman 2001). For instance, Reyna-Villasmil 2007 found that oat-derived betaglucan, when added to the American Heart Association Step 2 diet, improved the lipid profile of male participants with mild to moderate hypercholesterolaemia (Reyna-Villasmil 2007). In another study, ingesting oat cereal for six weeks was found to significantly reduce systolic blood pressure and diastolic blood pressure in hypertensive and hyperinsulinaemic participants when compared to a low-fibre cereal (Keenan 2002). Evidence also comes from systematic reviews of experimental studies. Streppel 2005 conducted a systematic review looking at dietary fibre and blood pressure and identified 24 relevant randomised controlled trials. The results from the meta-analyses showed that fibre supplementation caused a non significant reduction in systolic blood pressure but a significant reduction in diastolic blood pressure. Brown 1999 also conducted a systematic review examining dietary soluble fibre, but focused on blood cholesterol concentrations. They identified 67 controlled trials including 2990 participants that fulfilled their inclusion criteria and found that diets high in soluble fibre significantly reduced LDL and total cholesterol levels.

\section{Why it is important to do this review}

Few systematic reviews have been conducted that solely examine dietary fibre for CVD prevention. Those that have been carried out did not look at CVD events (Brown 1999; Streppel 2005; Whitehead 2014), involved limited searching (Streppel 2005), and did not assess the methodological rigour of their included studies (Brown 1999; Streppel 2005). With this in mind, we undertook this review to update current evidence on dietary fibre for the primary prevention of CVD by examining evidence from RCTs of dietary fibre in the general population as well as people at high risk of CVD. We included interventions of dietary advice to increase fibre consumption and the provision of high-fibre foods and fibre supplements.

\section{OB JECTIVES}

The primary objective of this systematic review was to determine the effectiveness of dietary fibre for the primary prevention of CVD.

\section{METHODS}

\section{Criteria for considering studies for this review \\ Types of studies}

Eligible studies were RCTs. We included studies reported as full text, those published as abstract only, and unpublished data.

\section{Types of participants}

Adults (age 18 and over) who are at high risk of CVD and adults from the general population in primary prevention trials were eligible. We excluded participants with the following comorbidities/characteristics:

- those who have experienced a previous myocardial infarction (MI) or stroke, or both;

- those who have undergone a revascularisation procedure (coronary artery bypass grafting (CABG) or percutaneous transluminal coronary angioplasty (PTCA));
- those with angina or angiographically-defined coronary heart disease (CHD);

- those with type 2 diabetes, although this is a major risk factor for CVD, as interventions for the treatment and management of type 2 diabetes are covered by reviews registered with the Cochrane Metabolic and Endocrine Disorders Group.

\section{Types of interventions}

We included trials comparing dietary fibre with no intervention or minimal intervention (for example leaflets with no person-toperson intervention or reinforcement). The intervention was in the form of advice to increase consumption or the provision of fibre supplements or high-fibre foods. Where we found a sufficient number of trials, we stratified results by the type of fibre (soluble or insoluble), dose of supplementation, duration of intervention, and type of intervention (advice, diet, or supplementation).

We excluded multi-factorial lifestyle intervention trials and trials focused on weight loss in order to avoid confounding. We also focused on follow-up periods of 12 weeks (or three months) or more, as longer follow-up periods are more relevant for public health interventions.

\section{Types of outcome measures}

\section{Primary outcomes}

- All-cause mortality

- Cardiovascular mortality

- Non-fatal endpoints such as MI, CABG, PTCA, angina, angiographically-defined CHD, stroke, carotid endarterectomy, peripheral arterial disease (PAD)

\section{Secondary outcomes}

- Changes in blood pressure (systolic and diastolic) and blood lipids (total cholesterol, high-density lipoprotein (HDL) cholesterol, low-density lipoprotein (LDL) cholesterol, triglycerides)

- Occurrence of type 2 diabetes as a major CVD risk factor

- Health-related quality of life

- Adverse effects

- Costs

\section{Search methods for identification of studies}

\section{Electronic searches}

We identified trials through systematic searches of the following bibliographic databases:

- The Cochrane Central Register of Controlled Trials (CENTRAL) (The Cochrane Library Issue 12, 2014)

- The Database of Abstracts of Reviews of Effects (DARE) (The Cochrane Library Issue 4, 2014)

- The NHS Economic Evaluation Database (NEED) (The Cochrane Library Issue 4, 2014)

- The Health Technology Assessment (HTA) Database (The Cochrane Library Issue 4, 2014)

- Ovid MEDLINE (1946 to January Week 12015$)$

- Ovid EMBASE and EMBASE Classic (1947 to 12 January 2015) 
- Science Citation Index Expanded, Social Sciences Citation Index, and Conference Proceedings Citation Index - Science on Web of Science Core Collection (Thomson Reuters) (1970 to 12 January 2015)

We adapted the preliminary search strategy for MEDLINE (Ovid) (Appendix 1) for use in the other databases. We applied the Cochrane sensitivity-maximising RCT filter (Lefebvre 2011) to MEDLINE (Ovid) and adaptations of it to the other databases, except CENTRAL, DARE, NEED and HTA.

We also conducted a search of ClinicalTrials.gov (www.ClinicalTrials.gov) and the World Health Organization International Clinical Trials Registry Platform Search Portal (http:// apps.who.int/trialsearch/).

We searched all databases from their inception to the present, and we imposed no restriction on language of publication.

\section{Searching other resources}

We checked reference lists of all primary studies and review articles for additional references. We also, where necessary, contacted authors for additional information.

\section{Data collection and analysis}

\section{Selection of studies}

Two authors ( $\mathrm{LH}$ and MM) independently screened titles and abstracts for inclusion and coded them as 'retrieve' (eligible or potentially eligible/unclear) or 'do not retrieve'. We retrieved the full-text study reports/publications, and two authors (LH and MM) independently screened the full text to identify studies for inclusion, and identify and record reasons for exclusion of the ineligible studies. We resolved any disagreement through discussion or, where required, we consulted a third author (KR). We identified and excluded duplicates and collated multiple reports of the same study so that each study, rather than each report, was the unit of interest in the review. We recorded the selection process in sufficient detail to complete a PRISMA flow diagram (Figure 1) and Characteristics of excluded studies table (Moher 2009). 
Figure 1. Study flow diagram.

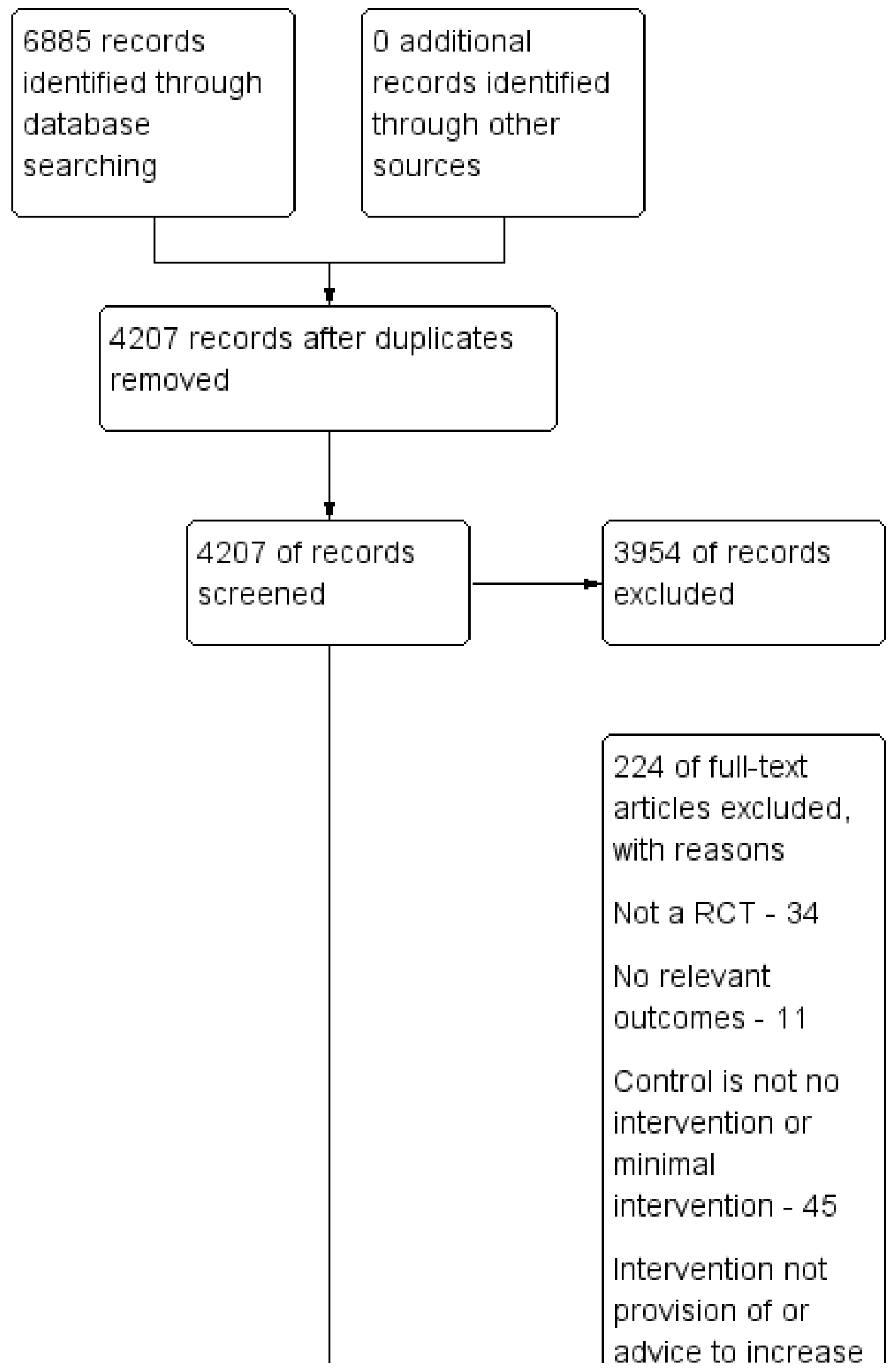


Figure 1. (Continued)

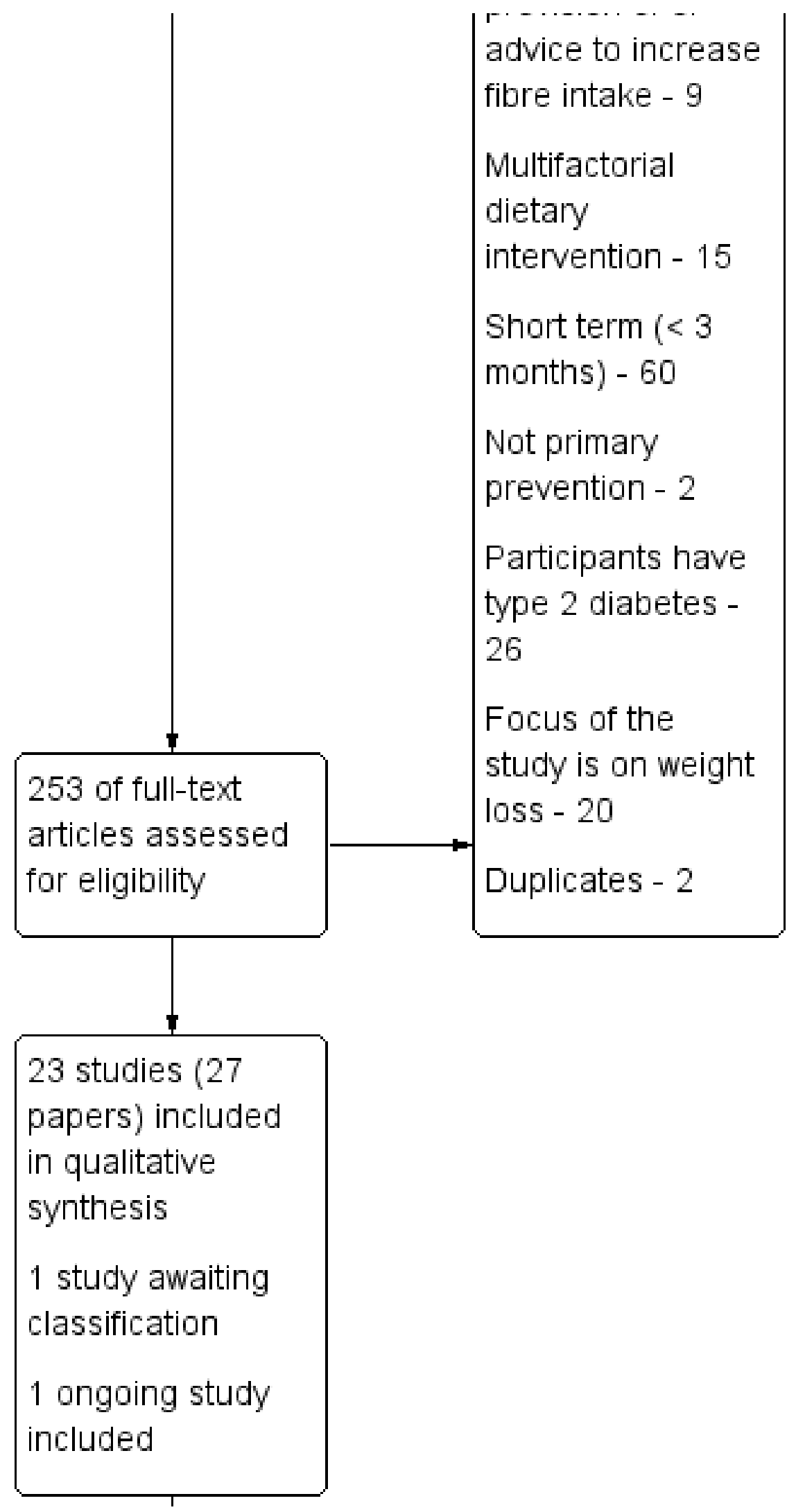


Figure 1. (Continued)

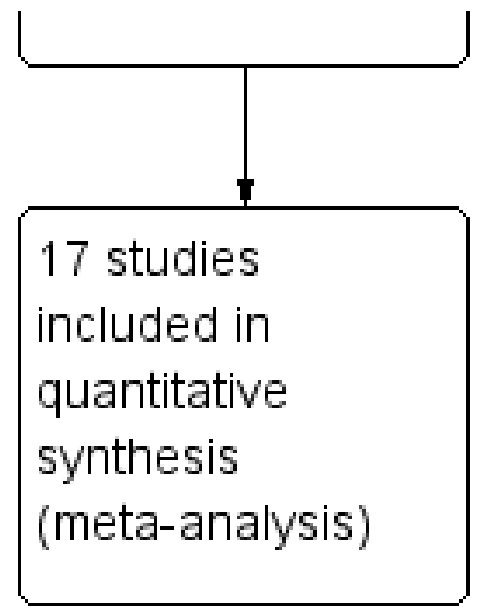

\section{Data extraction and management}

We used a piloted data collection form for study characteristics and outcome data. Two authors (LH, MM or JC) extracted study characteristics from included studies. We extracted the following study characteristics.

- Methods: study design, total duration of study, details of any 'run in' period, number of study centres and location, study setting, withdrawals, and date of study.

- Participants: number $(\mathrm{N})$, mean age, age range, gender, severity of condition, diagnostic criteria, inclusion criteria, and exclusion criteria.

- Interventions: intervention, comparison, concomitant medications, and excluded medications.

- Outcomes: primary and secondary outcomes specified and collected, and time points reported.

Two authors (LH, MM or JC) independently extracted outcome data from included studies. A third author (EL) resolved disagreements between the two reviewers. One author (EL) transferred data into a Review Manager (RevMan 2014) file. We double-checked that data was entered correctly by comparing the data presented in the systematic review with the study reports. A second author (KR) spot-checked study characteristics for accuracy against the trial report.

\section{Assessment of risk of bias in included studies}

Two authors (LH, MM or JC) independently assessed risk of bias for each study using the criteria outlined in the Cochrane Handbook for Systematic Reviews of Interventions (Higgins 2011a). We resolved any disagreements by discussion or by involving another author (EL or KR). We assessed the risk of bias according to the following domains.

- Random sequence generation

- Allocation concealment

- Blinding of participants and personnel

- Blinding of outcome assessment

- Incomplete outcome data

- Selective outcome reporting

- Other bias (e.g. industry funding)
We graded each potential source of bias as high, low, or unclear and provide a quote from the study report together with a justification for our judgement in the Risk of bias section as part of the Characteristics of included studies table. We summarised the riskof-bias judgements across different studies for each of the domains listed. Where information on risk of bias relates to unpublished data or correspondence with a trialist, we noted this in the Risk of bias section.

When considering treatment effects, we took into account the risk of bias for the studies that contribute to that outcome.

\section{Assessment of bias in conducting the systematic review}

We conducted the review according to the published protocol and report any deviations from it in the Differences between protocol and review section of the systematic review.

\section{Measures of treatment effect}

We analysed dichotomous data as odds ratios (OR) or risk ratios (RR) with 95\% confidence intervals $(\mathrm{Cl})$ and continuous data as mean difference (MD) or standardised mean difference (SMD) with $95 \% \mathrm{Cl}$. For continuous variables we presented data for the change from baseline rather than end-point data. We entered data presented as a scale with a consistent direction of effect, with the exception of HDL cholesterol where an increase in this outcome is a positive finding.

We narratively described skewed data reported as medians and interquartile ranges.

\section{Unit of analysis issues}

\section{Studies with multiple intervention groups}

In these cases, we used data from the control group for each intervention group comparison. We reduced the weight assigned to the control group by dividing the control group $\mathrm{N}$ by the number of intervention groups.

\section{Cross-over trials}

We included cross-over trials by using data only from the first half as a parallel group design. We only considered risk factor changes (for example, blood lipid levels and blood pressure) before participants 
crossed over to the other therapy and where the duration of intervention was a minimum of three months before cross-over.

\section{Cluster randomised trials}

We aimed to analyse cluster randomised trials by using the cluster (unit of randomisation) as the number of observations. Where needed, the individual level means and standard deviations adjusted for clustering would have been utilised together with the number of clusters in the denominator to appropriately weight the trials.

\section{Dealing with missing data}

We contacted investigators or study sponsors to verify key study characteristics and obtain missing numerical outcome data where possible (for example when a study is identified as abstract only). Where papers did not report results as change from baseline we calculated this and for the standard deviation differences followed the methods presented in the Cochrane Handbook for Systematic Reviews of Interventions for imputing these (16.1.3.2 Imputing standard deviations for changes from baseline Higgins 2011b), and assumed a correlation of 0.5 between baseline and follow-up measures as suggested by Follman 1992.

\section{Assessment of heterogeneity}

We used the $\mathrm{I}^{2}$ statistic to measure heterogeneity among the trials in each analysis (Higgins 2003). Where we identified substantial heterogeneity (greater than 50\%), we reported it and explored possible causes by pre-specified subgroup analysis.

\section{Assessment of reporting biases}

Where we were able to pool more than 10 trials, we created and examined a funnel plot to explore possible small-study biases for the primary outcomes (Sterne 2011).

\section{Data synthesis}

We undertook meta-analyses only where this was meaningful, that is if the treatments, participants, and the underlying clinical question were similar enough for pooling to make sense. Where there was no heterogeneity between included studies, we performed a fixed-effect meta-analysis. Where we detected substantial heterogeneity ( 12 greater than $50 \%)$ and could not explain it, we considered the following options: providing a narrative overview and not aggregating studies, or using a randomeffects model with appropriately cautious interpretation.

\section{Subgroup analysis and investigation of heterogeneity}

We planned to carry out the following subgroup analyses.

- Type of fibre (soluble and insoluble)

- Dose of supplement

- Duration of intervention

- Type of intervention (fibre supplementation, provision of highfibre foods, and advice to increase fibre consumption)

However, data were only available to undertake subgroup analyses on the type of fibre and the type of intervention.

We used the following outcomes in subgroup analyses.
- Blood lipids (total cholesterol, HDL cholesterol, LDL cholesterol, triglycerides).

We used the formal test for subgroup interactions in Review Manager (RevMan 2014).

\section{Sensitivity analysis}

We planned to carry out sensitivity analyses looking at studies with a low risk of bias. However, no studies met this criteria (see Risk of bias in included studies). One study reported a high loss to follow up (>20\%) but this study did not report any data that could be included in the meta-analysis and therefore no sensitivity analysis was required.

\section{Reaching conclusions}

We based our conclusions only on findings from the quantitative or narrative synthesis of included studies for this review. We have avoided making recommendations for practice, and our 'Implications for research' suggests priorities for future research and outlines the remaining uncertainties in the area.

\section{RE S U L T S}

\section{Description of studies}

\section{Results of the search}

The searches generated 4207 hits after duplicates were removed. Screening of titles and abstracts identified 253 papers to go forward for formal inclusion and exclusion. Twenty three randomised controlled trials fulfilled the inclusion criteria and were included in the review. For a detailed description of the included studies see 'Characteristics of included studies'. One ongoing study was also identified and is reported in Characteristics of ongoing studies. One study is awaiting classification and is reported in Characteristics of studies awaiting classification. The flow of studies through the review is presented in Figure 1.

\section{Included studies}

\section{Types of studies}

Twenty three studies (in 27 publications) were included. Twenty were parallel RCTs and three were cross-over studies. One crossover study was a cluster RCT (Nichenametla 2014), the remaining 22 trials were individually randomised. Of the studies, six were conducted in the USA. The other studies were conducted in Europe (Denmark, Finland, France, Italy, Norway, Spain, UK), Mexico, Japan, China or Australia. Only four studies reported the setting for the intervention, this was a university research clinic in one (PerezJiminez 2008) and an outpatient setting another (Maki 2007) and two studies were set in the community (Nichenametla 2014; Pal 2011). Only one study reported the dates of the study (Tighe 2010 Wheat, being June 2005 to September 2008); the publication dates of all studies ranged from 1984 to 2014, with the majority being published after the year 2000 .

The majority of trials were two-arm trials comparing the intervention with a placebo or control (18 trials). Of the remaining trials, four had three arms (in one study, Gato 2013, the third arm was irrelevant to this review) and one was a four-arm trial (although one arm was not relevant to this review, Pal 2011).

- Changes in blood pressure (systolic and diastolic) 


\section{Overview of study populations}

Trial sample sizes were generally small. Overall, 1513 participants were included in the trials. Six parallel trials and the one cluster RCT included study arms with 40 participants or more (Cicero 2010 Pysllium; He 2004; Lehtimaki 2005; Maki 2007; Nichenametla 2014; Pins 2002; Tighe 2010 Wheat). Other studies had fewer than 40 participants per study arm, with three studies including fewer than ten participants per arm (Aro 1984; Forcheron 2007; HernandezGonzalez 2010).

Participants were described as 'healthy' in four studies (Forcheron 2007; He 2004; Jackson 1999; Marett 2004 Larch). In six studies participants were described as being overweight or obese (Birketvedt 2002; Hashizume 2012; Hernandez-Gonzalez 2010; Hu 2013; Pal 2011; Reimer 2013) and in three studies as having metabolic syndrome or signs of metabolic syndrome (Cicero 2010 Pysllium; Nichenametla 2014; Tighe 2010 Wheat). In three studies participants were described as having hypertension (Maki 2007; Pins 2002; Schlamovitz 1987). One study included women described as having climacteric symptoms (Makkonen 1993). The remaining six trials included participants with some degree of hypercholesterolaemia (Aro 1984; Gato 2013; Haskell 1992; Lehtimaki 2005; Perez-Jiminez 2008; Shimizu 2008).

Where reported, the mean age of participants was in the region of 35 years to 58 years in most studies. Two studies included participants between the ages of 19 years and 39 years (Forcheron 2007; Hu 2013) and one included participants aged 60 years to 61 years (Hashizume 2012). The proportion of male participants, where reported, was in the region of $32 \%$ to $73 \%$ with the exception of two studies, one which only included men (Aro 1984) and one which only included women (Makkonen 1993).

\section{Description of interventions}

In 15 studies the intervention was the provision of a fibre supplement. Eleven of these had a 12 week to 16 week followup, which was immediately at the end of the intervention in all except one study (Jackson 1999). Of these 15 studies, 14 had placebo comparisons, with the remaining study (Perez-Jiminez 2008) having a usual diet control group. Four studies had a sixmonth intervention with immediate follow-up. All except one study used a placebo comparator; Cicero 2010 Pysllium had dietary advice as the comparator. The fibre supplements included in these studies varied. Supplements in 12 studies were judged to be soluble fibre (Aro 1984; Cicero 2010 Pysllium; Forcheron 2007; Haskell 1992; Hernandez-Gonzalez 2010; Jackson 1999; Lehtimaki 2005; Makkonen 1993; Marett 2004 Larch; Pal 2011; Reimer 2013;
Schlamovitz 1987); in two studies insoluble fibre (Nichenametla 2014; Perez-Jiminez 2008) and in one study a combination of soluble and insoluble fibre (Birketvedt 2002).

In eight studies the intervention was the provision of foods high in fibre. All of these studies had an intervention and follow-up of 12 weeks duration. Of these studies five provided foods that were soluble fibre sources (Gato 2013; Hashizume 2012; He 2004; Maki 2007; Pins 2002); in two the fibre source was insoluble (Shimizu 2008; and one group of a three arm study Tighe 2010 Wheat); and in two a combination of soluble and insoluble fibre (Hu 2013; and one group of a three arm study, Tighe 2010 Wheat+Oats).

\section{Outcomes included}

None of the studies reported on mortality (total or cardiovascular) or cardiovascular events. In 22 studies lipid levels were outcomes and in twelve of these blood pressure was also reported as an outcome. One study (Maki 2007) only reported blood pressure as an outcome. Fourteen included studies reported adverse events, although there were limited details provided (Birketvedt 2002; Cicero 2010 GuarGum; Forcheron 2007; Hashizume 2012; Haskell 1992; He 2004; Hu 2013; Makkonen 1993; Marett 2004 Larch; Nichenametla 2014; Perez-Jiminez 2008; Pins 2002; Reimer 2013; Schlamovitz 1987).

No data for outcomes were reported in three studies (Gato 2013; Lehtimaki 2005; Maki 2007). One cross-over cluster RCT (Nichenametla 2014) did not report data for the first half of the trial and therefore we could not analyse data as specified in the review protocol.

One study is awaiting classification as the library were unable to locate it (Keenan 2002b). It is a costing study for one of the included studies (Pins 2002) and data on costs will be abstracted and included in the review when the paper becomes available.

\section{Excluded studies}

Details and reasons for exclusion for studies that closely missed the inclusion criteria are provided in the Characteristics of excluded studies table. Reasons for exclusion for the majority of studies included short term studies ( $<3$ months), the control group not being either no intervention or minimal intervention and alternative designs (not RCTs) (see Figure 1).

\section{Risk of bias in included studies}

A large proportion of studies were rated as unclear on many risk of bias domains (see Figure 2; Figure 3). 
Figure 2. Risk of bias summary: review authors' judgements about each risk of bias item for each included study.

\begin{tabular}{|c|c|c|c|c|c|c|c|}
\hline & 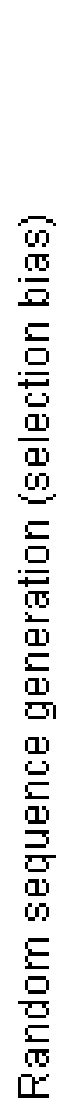 & 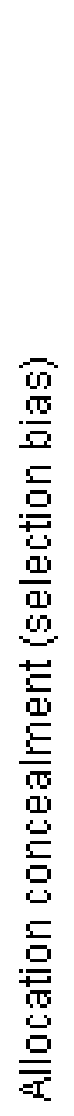 & 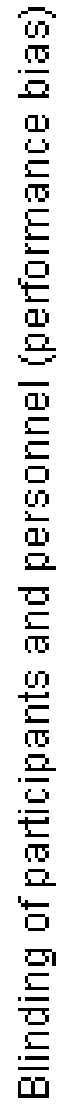 & 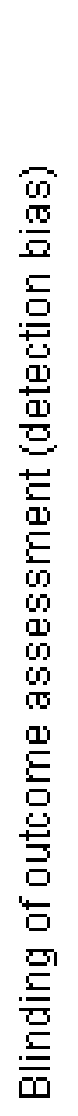 & 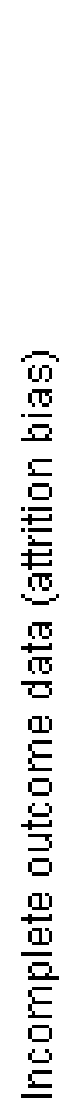 & 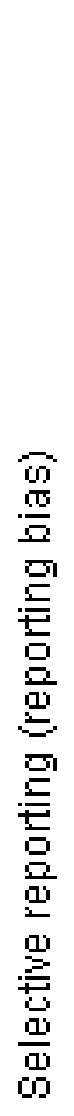 & 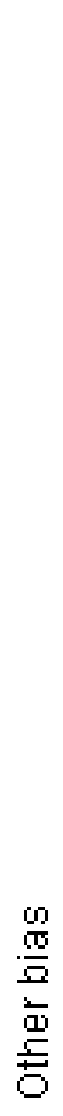 \\
\hline Aro 1984 & $?$ & $?$ & + & $?$ & + & $?$ & $?$ \\
\hline Birketvedt 2002 & $?$ & $?$ & $?$ & $?$ & $?$ & $?$ & $?$ \\
\hline Cicero 2010 GuarGum & + & + & & $?$ & $?$ & $?$ & $?$ \\
\hline Cicero 2010 Pysllium & + & + & & $?$ & $?$ & $?$ & $?$ \\
\hline Forcheron 2007 & $?$ & $?$ & & $?$ & & $?$ & $?$ \\
\hline Gato 2013 & $?$ & $?$ & & $?$ & + & & $?$ \\
\hline Hashizume 2012 & $?$ & $?$ & + & $?$ & $?$ & $?$ & $?$ \\
\hline Haskell 1992 & $?$ & $?$ & + & $?$ & $?$ & $?$ & $?$ \\
\hline $\mathrm{He} 2004$ & + & + & & + & $?$ & $?$ & $?$ \\
\hline nandez-Gonzalez 2010 & $?$ & $?$ & + & $?$ & $?$ & $?$ & ? \\
\hline
\end{tabular}


Figure 2. (Continued)

\begin{tabular}{|c|c|c|c|c|c|c|c|}
\hline Hernandez-Gonzalez 2010 & $?$ & $?$ & & $?$ & $?$ & $?$ & ? \\
\hline $\mathrm{Hu} 2013$ & $?$ & $?$ & $?$ & $?$ & & $?$ & $?$ \\
\hline Jackson 1999 & $?$ & $?$ & & $?$ & & $?$ & $?$ \\
\hline Lehtimaki 2005 & $?$ & $?$ & & $?$ & & & ? \\
\hline Maki 2007 & $?$ & $?$ & & $?$ & & & ? \\
\hline Makkonen 1993 & $?$ & $?$ & & $?$ & $?$ & $?$ & ? \\
\hline Marett 2004 Larch & $?$ & $?$ & & $?$ & $?$ & & ? \\
\hline Marett 2004 Tamarak & $?$ & $?$ & & $?$ & $?$ & & ? \\
\hline Nichenametla 2014 & $?$ & $?$ & & $?$ & $?$ & $?$ & \\
\hline Pal 2011 & ? & $?$ & & $?$ & & $?$ & $?$ \\
\hline Perez-Jiminez 2008 & $?$ & $?$ & $?$ & $?$ & & $?$ & $?$ \\
\hline Pins 2002 & $?$ & $?$ & & + & & $?$ & \\
\hline Reimer 2013 & $?$ & $?$ & & $?$ & $?$ & $?$ & $?$ \\
\hline Schlamovit 1987 & $?$ & $?$ & & $?$ & $?$ & & ? \\
\hline Shimizu 2008 & ? & $?$ & & $?$ & & $?$ & $?$ \\
\hline Tighe 2010 Wheat & & & & 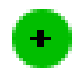 & & $?$ & $?$ \\
\hline Tighe 2010 Wheat+oats & & & & + & & $?$ & $?$ \\
\hline
\end{tabular}


Figure 3. Risk of bias graph: review authors' judgements about each risk of bias item presented as percentages across all included studies.

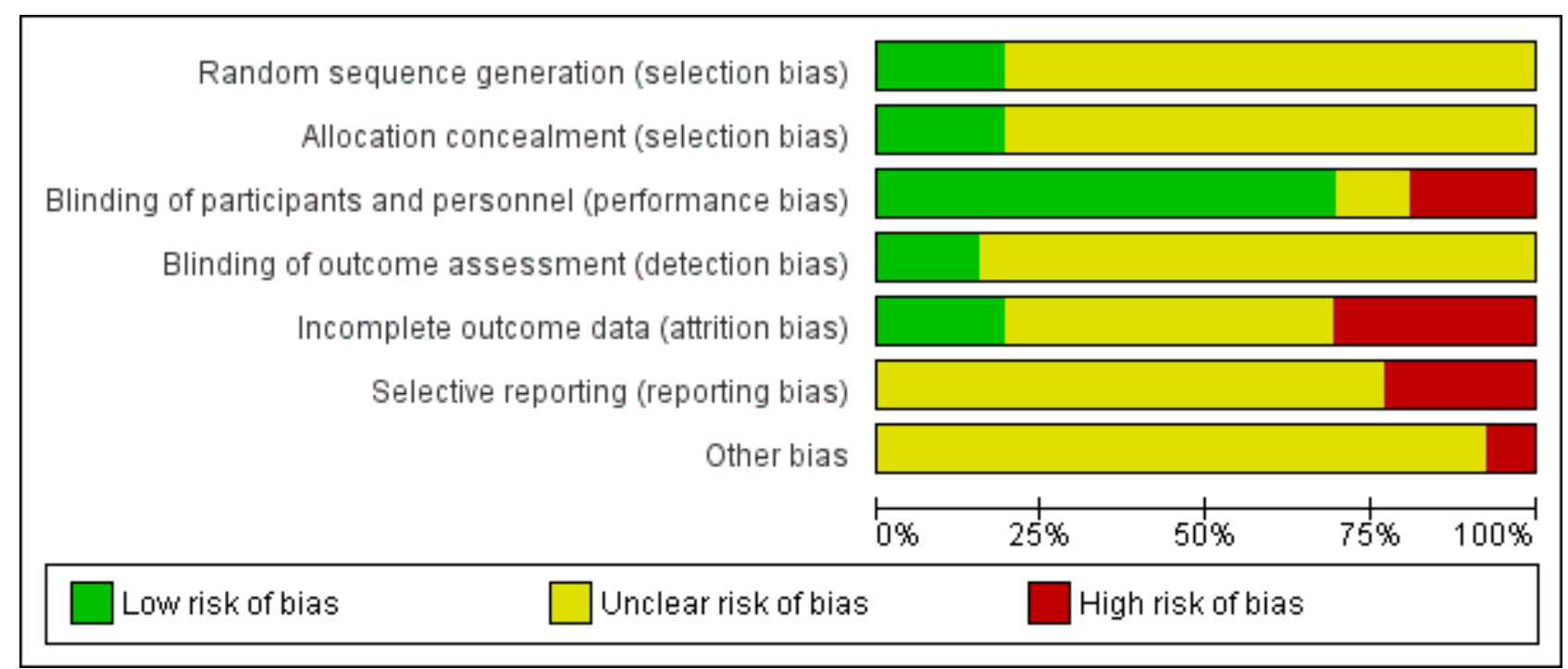

\section{Allocation}

Only three of 23 studies reported an adequate method of randomisation (Cicero 2010 Pysllium; He 2004; Tighe 2010 Wheat). These three studies also adequately reported the allocation concealment.

\section{Blinding}

Adequate blinding of participants and personnel were reported in 17 studies (Aro 1984; Forcheron 2007; Gato 2013; Hashizume 2012; Haskell 1992; He 2004; Hernandez-Gonzalez 2010; Jackson 1999; Lehtimaki 2005; Maki 2007; Makkonen 1993; Marett 2004 Larch; Nichenametla 2014; Pins 2002; Reimer 2013; Schlamovitz 1987; Shimizu 2008). In one study participants and personnel were unblinded (Cicero 2010 Pysllium) and in another the study was reported to be 'single' blind only (Pal 2011). In the remaining four studies blinding or participants and personnel was judged as unclear.

Adequate blinding of outcome assessors was reported in only two studies (He 2004; Tighe 2010 Wheat), the remaining studies were judged as unclear for detection bias.

\section{Incomplete outcome data}

Three studies did not have any missing data and were judged to be at low risk of attrition bias (Aro 1984; Gato 2013; Pins 2002). Four studies reported different rates of drop outs or withdrawals between study groups (Lehtimaki 2005; Pal 2011; Perez-Jiminez 2008; Tighe 2010 Wheat); two studies reported drop outs or withdrawals for the total population but not per study group (Forcheron 2007; Shimizu 2008) and one study reported high loss to follow-up (Maki 2007). For the remaining studies this was not reported and judged at unclear risk of bias.

\section{Selective reporting}

Five studies did not report all outcomes as stated (Gato 2013; Lehtimaki 2005; Maki 2007; Marett 2004 Larch; Schlamovitz 1987), in three of these (Gato 2013; Lehtimaki 2005; Maki 2007) no data for any outcomes were reported.
Most other studies appeared to report all outcomes as intended, however, not enough information is available to check and these have been judged as unclear.

\section{Other potential sources of bias}

One cluster crossover randomised study (Nichenametla 2014) reported only two clusters and there was evidence of a carry-over effect, although we only intended to use data from the first half of the trial before crossover. One study was funded by the industry providing the cereals for the intervention and was judged to be at high risk (Pins 2002). For the remaining studies this was not reported and judged at unclear risk of bias.

\section{Effects of interventions}

Three trials did not report data (Gato 2013; Lehtimaki 2005; Maki 2007), one trial did not report data that could be included in the pooled analysis (Pal 2011), and two cross-over studies (one also a cluster RCT) (Aro 1984; Nichenametla 2014) did not report data for the first half of the trial and therefore data could not be analysed as specified in the review protocol.

There were no data on the primary outcomes of the review.

\section{Blood lipids}

Total cholesterol. Eighteen studies reported total cholesterol and 17 of these could be summarised in a meta-analysis (20 comparisons) Analysis 1.1. The pooled analysis showed a significant difference between comparison groups where fibre decreased total cholesterol (MD $-0.20 \mathrm{mmol} / \mathrm{L}, 95 \% \mathrm{Cl}-0.34$ to -0.06 $P=0.004)$. There was moderate heterogeneity $\left(P=0.001 ; I^{2}=46 \%\right)$ and results were pooled with a random-effects model.

One trial provided data that could not be included in the pooled analysis. Pal 2011 reported the percentage change in total cholesterol for their trial. Results showed that the fibre supplement (psyllium) group had a $21 \%$ reduction in total cholesterol compared to the control group $(P<0.001)$. 
As no studies reported the review's primary outcomes a funnel plot was generated for total cholesterol as this analysis included the highest number of studies on which to assess publication bias. Inspection of the funnel plot suggests the possibility of publication bias (Figure 4).

Figure 4. Funnel plot of comparison: 1 Fibre versus control, outcome: 1.1 Total Cholesterol mmol/L change.

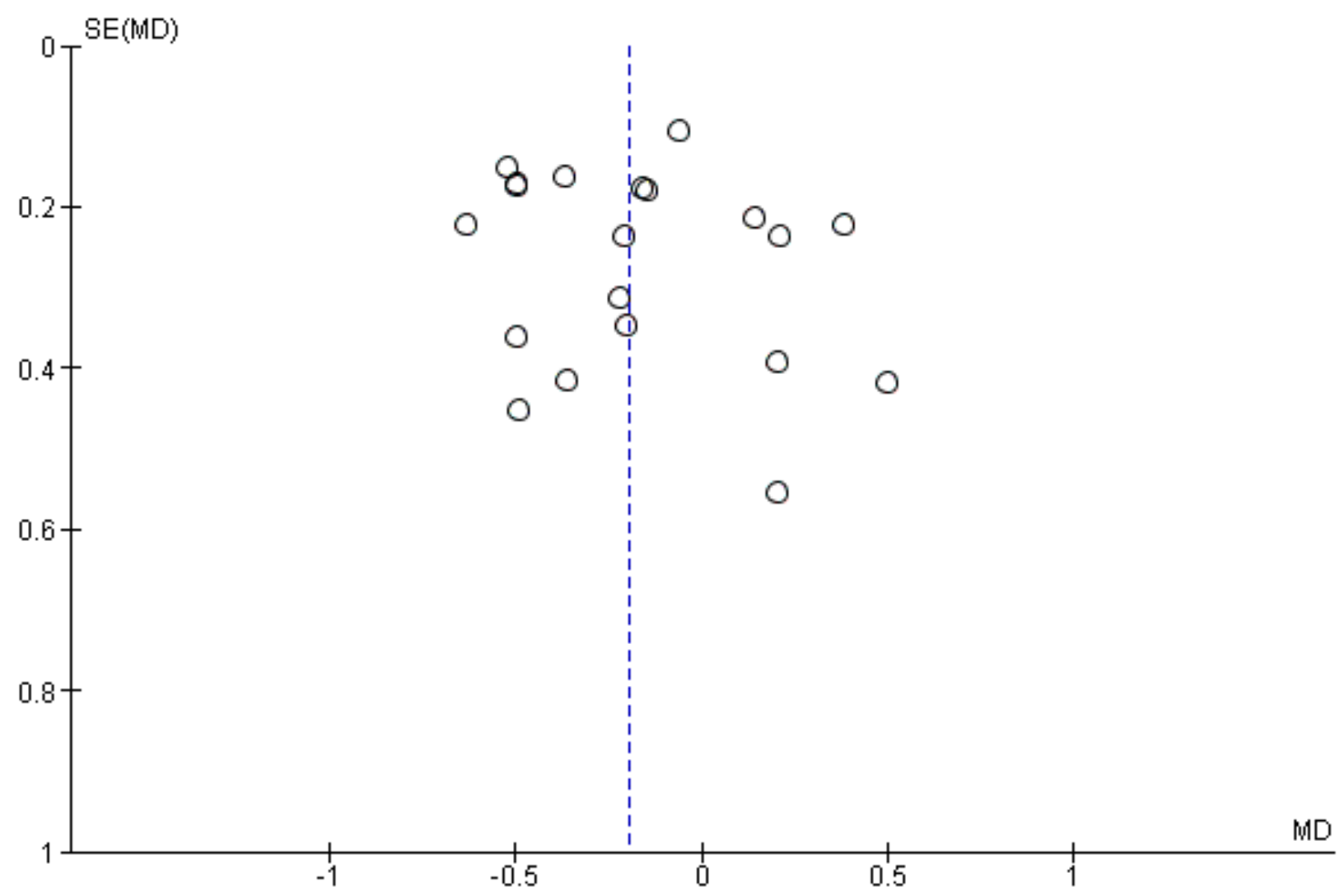

HDL cholesterol. Sixteen studies reported HDL cholesterol and 15 of these could be summarised in a meta-analysis ( 18 comparisons) Analysis 1.2. The pooled analysis showed a small but significant difference between comparison groups favouring the control (an increase in HDL is beneficial and the direction of effect on the graphs have been changed for this outcome to illustrate this) (MD - $0.03 \mathrm{mmol} / \mathrm{L}, 95 \% \mathrm{Cl}-0.06$ to $-0.01 ; \mathrm{P}=0.02$ ). There was no significant heterogeneity $(P=0.70 ; 12=0 \%)$. One trial provided data that could not be included in the pooled analysis. Pal 2011 reported that there were no significant differences in the percentage change in HDL cholesterol between groups (fibre supplement, fibre supplement and dietary advice, and control) in their three-arm RCT.

LDL cholesterol. Sixeen studies reported LDL cholesterol and 15 of these could be summarised in a meta-analysis (18 comparisons) Analysis 1.3. The pooled analysis showed a significant difference between comparison groups favouring fibre (MD $-0.14 \mathrm{mmol} /$ $\mathrm{L}, 95 \% \mathrm{Cl}-0.22$ to $-0.06 ; \mathrm{P}=0.0006)$. There was no significant heterogeneity $\left(P=0.07 ; 1^{2}=36 \%\right)$. One trial provided data that could not be included in the pooled analysis. Pal 2011 reported the percentage change in LDL cholesterol. Results showed that the fibre supplement group had a $27 \%$ reduction in LDL cholesterol compared to the control group $(P<0.001)$.
Triglycerides. Sixeen studies reported triglycerides and 15 of these could be summarised in a meta-analysis (18 comparisons) Analysis 1.4. The pooled analysis showed no significant difference between comparison groups (MD $0.00 \mathrm{mmol} / \mathrm{L}, 95 \% \mathrm{Cl}-0.04$ to $0.05 ; \mathrm{P}=$ $0.88)$. There was no significant heterogeneity $\left(P=0.09 ; 1^{2}=32 \%\right)$. One trial provided data that could not be included in the pooled analysis. Pal 2011 reported the percentage change in triglycerides and showed that there was no significant difference between the fibre supplement and control group.

\section{Blood pressure}

Systolic blood pressure. Eight studies reported systolic blood pressure (SBP) and could be summarised in a meta-analysis (10 comparisons) Analysis 1.5. The pooled analysis showed a reduction in SBP with the intervention but this did not reach statistical significance (MD $-1.92 \mathrm{mmHg}, 95 \% \mathrm{Cl}-4.02$ to $0.19 ; \mathrm{P}=0.07)$. There was significant heterogeneity $\left(P=0.0006 ;\left.\right|^{2}=69 \%\right)$ and results were pooled with a random-effects model.

Diastolic blood pressure. Eight studies reported diastolic blood pressure and could be summarised in a meta-analysis (10 comparisons) Analysis 1.6. The pooled analysis showed a significant difference between comparison groups favouring fibre (MD $-1.77 \mathrm{mmHg}, 95 \% \mathrm{Cl}-2.61$ to $-0.92 ; \mathrm{P}<0.0001$ ). There was no significant heterogeneity $\left(P=0.37 ; 1^{2}=7 \%\right)$. 


\section{Subgroup analyses}

Results are presented as subgroup analyses for the lipids and blood pressure outcomes for the type of intervention (fibre supplements or provision of foods high in fibre) and type of fibre (soluble, insoluble, combined fibre sources). Caution is required in the interpretation of some of these subgroup comparisons owing to low numbers of studies for some of these (described below).

\section{Type of intervention}

There did not appear to be any trends in the subgroup analyses of trials providing foods high in fibre or trials providing fibre supplements for lipids (Analysis 2.1; Analysis 2.2; Analysis 2.3; Analysis 2.4). For blood pressure there were no significant subgroup effects seen for systolic blood pressure (Analysis 2.5) but there was a difference in effect between supplements and foods high in fibre for diastolic blood pressure in favour of providing foods high in fibre (Analysis 2.6) however this did not reach statistical significance ( $P$ $\left.=0.13 ; 1^{2}=57.50 \%\right)$.

\section{Type of fibre}

In general it is difficult to establish any pattern in the study results for the subgroup looking at the source of fibre (soluble, insoluble or soluble and insoluble) owing to the small number of comparisons in the latter two subgroups. There were no statistically significant subgroup effects for lipids or systolic blood pressure. There was a difference in effect in fibre type for diastolic blood pressure with the largest effects seen for a combination of both soluble and insoluble fibre (Analysis 2.12), but this did not reach statistical significance $(P$ $\left.=0.06 ; 1^{2}=64.20 \%\right)$.

\section{Adverse events}

Fourteen trials reported information on adverse events. One study reported that no adverse effects of the interventions were observed (Forcheron 2007). One study reported that combined dietary (flatulence and diarrhoea) and antihypertensive medication side-effects scores decreased from baseline in the intervention but not the control group (Pins 2002). Four studies reported that participants had only a few gastrointestinal sideeffects and that rates did not appear to differ between study groups (Hu 2013; Marett 2004 Larch; Reimer 2013; Schlamovitz 1987). Gastrointestinal side effects (predominantly flatulence but also constipation, nausea, bloating and diarrhoea) were more commonly reported in the fibre intervention groups than control groups in seven studies, although rates were generally low (Birketvedt 2002; Cicero 2010 GuarGum; Hashizume 2012; Haskell 1992; He 2004; Makkonen 1993; Perez-Jiminez 2008). One cluster cross over trial only reported rates for the total population at the end of the intervention (Nichenametla 2014).

The remaining trials did not report on adverse events.

\section{ISCUSSION}

\section{Summary of main results}

This systematic review summarised 23 RCTs examining the effect of dietary fibre on risk factors for cardiovascular disease. None of the studies reported on mortality (total or cardiovascular) or cardiovascular events, the review's primary outcomes. Studies were at risk of bias, few studies had an intervention duration of longer than 12 weeks and samples sizes were generally small.
There was a wide variety of fibre sources used, with little similarity between groups in the choice of intervention.

Overall, there appears to be a significant effect of increased fibre on total cholesterol levels (MD $-0.20 \mathrm{mmol} / \mathrm{L}, 95 \% \mathrm{Cl}-0.34$ to -0.06 ), and $\mathrm{LDL}$ cholesterol levels (MD $-0.14 \mathrm{mmol} / \mathrm{L}, 95 \% \mathrm{Cl}-0.22$ to -0.06 ) but this effect is not demonstrated on triglyceride levels (MD 0.00 $\mathrm{mmol} / \mathrm{L}, 95 \% \mathrm{Cl}-0.04$ to 0.05 ), and there was a very small but statistically significant decrease rather than increase in HDL levels with increased fibre intake (MD $-0.03 \mathrm{mmol} / \mathrm{L}, 95 \% \mathrm{Cl}-0.06$ to -0.01). Fewer studies reported blood pressure outcomes where it appears there is a significant effect of increased fibre consumption on diastolic blood pressure (MD $-1.77 \mathrm{mmHg}, 95 \% \mathrm{Cl}-2.61$ to -0.92 ) whilst there is a reduction in systolic blood pressure with fibre but this does not reach statistical significance (MD $-1.92 \mathrm{mmHg}$, $95 \% \mathrm{Cl}-4.02$ to 0.19 ). There did not appear to be any subgroup effects by the nature of the type of intervention (foods high in fibre versus fibre supplements) or the type of fibre (soluble or insoluble) although the number of studies contributing to each subgroup was small. All analyses need to be viewed with caution given the risks of bias of the studies, and for total cholesterol and systolic blood pressure, statistical heterogeneity was observed. Adverse events, where reported, appeared to mostly reflect mild to moderate gastrointestinal side-effects and these were generally reported more in the fibre intervention groups than the control groups.

\section{Overall completeness and applicability of evidence}

Whilst the number of trials meeting the inclusion criteria was relatively large, few studies had an intervention duration of longer than 12 weeks and samples sizes were generally small, so none reported on our primary outcomes, major CVD events.

There were a sufficient number of trials reporting our secondary outcomes, CVD risk factors, but heterogeneity between trials limited the findings, particularly for total cholesterol and systolic blood pressure where random-effects models were used to pool results. Heterogeneity between studies was due to the wide variety of fibre sources used and to differences in the participants recruited. We attempted to explore these differences in stratified analyses for fibre source (supplements versus provision of foods, and soluble versus insoluble fibre) where there were no obvious subgroup effects although the numbers of trials in each group were relatively small. There were insufficient trials to stratify results by cardiovascular risk.

\section{Quality of the evidence}

Trials were at risk of bias, with a large proportion of studies being rated as unclear on many quality criteria, and some studies at high risk of bias for individual quality domains.

The number of participants recruited was also generally small and so studies may be subject to small study bias (Nüesch 2010; Sterne 2000; Sterne 2001).

The was some evidence of publication bias from visual inspection of the funnel plot constructed for the outcome reported in most studies, total cholesterol Figure 4. 


\section{Potential biases in the review process}

The review authors carried out a comprehensive search across major databases for interventions involving dietary fibre for this review. In addition, the review authors screened the reference lists of systematic reviews and contacted study authors for information when needed. All screening, inclusion and exclusion and data abstraction were carried out independently by two review authors and analyses were conducted by one reviewer and checked by a second.

Multifactorial dietary interventions were excluded from this review because it would not be possible to disentangle the specific effects of fibre from other dietary interventions. We also excluded studies focusing on weight loss in order to reduce confounding. By restricting the comparison group to no intervention/placebo or minimal intervention we also reduced confounding. This did however limit the number of trials that were eligible for inclusion.

We excluded a large number of trials of short duration ( $<12$ weeks) as we were interested in the sustained and longer-term effects of increased fibre intake, as these are more relevant for public health interventions.

\section{Agreements and disagreements with other studies or reviews}

The Global Burden of Disease Study conducted in 2010 found diets low in fibre to be one of the dietary risk factors for ischaemic heart disease (Lim 2012) and estimated that $11 \%$ of the disabilityadjusted life years from ischaemic heart disease are attributable to diets low in fibre (Lim 2012). The primary source of this data is however from non-randomised studies. As demonstrated in the current systematic review, there is currently no RCT evidence on the effect of dietary fibre on mortality or heart disease.

There have been several previous systematic reviews examining the effects of increased fibre intake on cardiovascular risk factors on lipid levels (Brown 1999; Whitehead 2014) and blood pressure (Streppel 2005). These reviews used different inclusion criteria from the current review in terms of participants recruited (e.g. including patients with type 2 diabetes Whitehead 2014) and duration of interventions (e.g. including very short term studies Brown 1999), and were limited by searching (Streppel 2005) and lack of assessment of methodological quality (Brown 1999; Streppel 2005) so the results are not directly comparable. Nevertheless, our review is in broad agreement with previous reviews in terms of the effects of dietary fibre on total cholesterol, LDL cholesterol (Brown 1999; Whitehead 2014) and blood pressure (Streppel 2005).

\section{AUTHORS' CONCLUSIONS}

\section{Implications for practice}

Currently there is no evidence from RCTs of the effects of dietary fibre on CVD clinical events. There is some evidence to suggest dietary fibre reduces total and LDL cholesterol and diastolic blood pressure but it is unclear which type of fibre (soluble or insoluble) and whether fibre supplements or provision of foods high in fibre are most effective and so no recommendations can be made for changing practice.

\section{Implications for research}

The majority of studies were short term and therefore did not report CVD clinical events, and it is unclear if the positive effects seen on total and LDL cholesterol and diastolic blood pressure are sustained over time. Studies were at risk of bias and there was insufficient information to determine the effects of fibre type and administration on outcomes.There is therefore a need for longerterm, well-conducted RCTs to determine the effects of fibre type (soluble versus insoluble) and administration (supplements versus foods) on CVD events and risk factors for the primary prevention of CVD.

\section{ACKNOWLEDGEMENTS}

We are grateful to Nicole Martin for conducting the searches for this review. With thanks also to Dr Frank Theis for providing additional data for their trial (Tighe 2010 Wheat; Tighe 2010 Wheat+Oats ). 


\section{RE F E R E N C E S}

\section{References to studies included in this review}

\section{Aro 1984 \{published data only\}}

Aro A, Uusitupa M, Voutilainen E, Korhonen T. Effects of guar gum in male subjects with hypercholesterolemia. American Journal of Clinical Nutrition 1984;39:911-6.

\section{Birketvedt 2002 \{published data only\}}

Birketvedt GS, Travis A, Langbakk B, Florholmen JR. Dietary supplementation with bean extract improves lipid profile in overweight and obese subjects. Nutrition 2002;18:729-33.

\section{Cicero 2010 GuarGum \{published data only\}}

Cicero AFG, Derosa G, Bove M, Imola F, Borghi C, Gaddi AV. Psyllium improves dyslipidaemia, hyperglycaemia and hypertension, while guar gum reduces body weight more rapidly in patients affected by metabolic syndrome following an AHA Step 2 diet. Mediterranean Journal of Nutrition and Metabolism 2010;3:47-54.

\section{Cicero 2010 Pysllium \{published data only\}}

Cicero AFG, Derosa G, Bove M, Imola F, Borghi C, Gaddi AV. Psyllium improves dyslipidaemia, hyperglycaemia and hypertension, while guar gum reduces body weight more rapidly in patients affected by metabolic syndrome following an AHA Step 2 diet. Mediterranean Journal of Nutrition and Metabolism 2010;3:47-54.

\section{Forcheron 2007 \{published data only\}}

Forcheron F, Beylot M. Long-term administration of inulintype fructans has no significant lipid-lowering effect in normolipidemic humans. Metabolism 2007;56:1093-8.

\section{Gato 2013 \{published data only\}}

Gato N, Kadowaki A, Hashimoto N, Yokoyama S, Matsumoto K. Persimmon fruit tannin-rich fiber reduces cholesterol levels in humans. Annals of Nutrition \& Metabolism 2013;62:1-6.

\section{Hashizume 2012 \{published data only\}}

Hashizume C, Kishimoto Y, Kanahori S, Yamamoto T, Okuma K, Yamamoto K. Improvement effect of resistant maltodextrin in humans with metabolic syndrome by continuous administration. Journal of Nutritional Science and Vitaminology 2012;58:423-30.

\section{Haskell 1992 \{published data only\}}

Haskell WL, Spiller GA, Jensen CD, Ellis BK, Gates JE. Role of water-soluble dietary fiber in the management of elevated plasma cholesterol in healthy subjects. American Journal of Cardiology 1992;69:433-9.

\section{He 2004 \{published data only\}}

Chen J, He J, Wildman RP, Reynolds K, Streiffer RH, Whelton PK. A randomized controlled trial of dietary fiber intake on serum lipids. European Journal of Clinical Nutrition 2006;60:62-8.

* He J, Streiffer RH, Muntner P, Krousel-Wood MA, Whelton PK. Effect of dietary fiber intake on blood pressure: a randomized, double-blind, placebo-controlled trial. Journal of Hypertension 2004;22:73-80.

\section{Hernandez-Gonzalez 2010 \{published data only\}}

Hernández-González SO, González-Ortiz M, Martínez-Abundis E, Robles-Cervantes JA. Chitosan improves insulin sensitivity as determined by the euglycemic-hyperinsulinemic clamp technique in obese subjects. Nutrition Research 2010;30:392-5.

\section{Hu 2013 \{published data only\}}

Hu XJ, Gao JL, Zhang QY, Fu YQ, Li KL, Zhu SK, et al. Soy fiber improves weight loss and lipid profile in overweight and obese adults: a randomized controlled trial. Molecular Nutrition \& Food Research 2013;57:2147-54.

\section{Jackson 1999 \{published data only\}}

Jackson KG, Taylor GR, Clohessy AM, Williams CM. The effect of the daily intake of inulin on fasting lipid, insulin and glucose concentrations in middle-aged men and women. British Journal of Nutrition 1999;82:23-30.

\section{Lehtimaki 2005 \{published data only\}}

Lehtimaki T, Metso S, Ylitalo R, Rontu R, Nikkila M, Wuolijoki E, et al. Microcrystalline chitosan is ineffective to decrease plasma lipids in both apolipoprotein E epsilon 4 carriers and non-carriers: a long-term placebo-controlled trial in hypercholesterolaemic volunteers. Basic \& Clinical Pharmacology \& Toxicology 2005;97:98-100.

\section{Maki 2007 \{published data only\}}

Maki KC, Galant R, Samuel P, Tesser J, Witchger MS, RibayaMercado JD, et al. Effects of consuming foods containing oat beta-glucan on blood pressure, carbohydrate metabolism and biomarkers of oxidative stress in men and women with elevated blood pressure. European Journal of Clinical Nutrition 2007;61:786-95.

\section{Makkonen 1993 \{published data only\}}

Makkonen M, Simpanen AL, Saarikoski S, Uusitupa M, Penttila I, Silvasti M, et al. Endocrine and metabolic effects of guar gum in menopausal women. Gynecological Endocrinology 1993;7:135-41.

\section{Marett 2004 Larch \{published data only\}}

Marett R, Slavin JL. No long-term benefits of supplementation with arabinogalactan on serum lipids and glucose. Journal of the American Dietetic Association 2004;104:636-9.

\section{Marett 2004 Tamarak \{published data only\}}

Marett R, Slavin JL. No long-term benefits of supplementation with arabinogalactan on serum lipids and glucose. Journal of the American Dietetic Association 2004;104:636-9.

\section{Nichenametla 2014 \{published data only\}}

Nichenametla SN, Weidauer LA, Wey HE, Beare TM, Specker BL, Dey M. Resistant starch type 4-enriched diet lowered blood cholesterols and improved body composition in a double blind controlled cross-over intervention. Molecular Nutrition \& Food Research 2014;58:1365-9. 
Pal 2011 \{published data only\}

* Pal S, Khossousi A, Binns C, Dhaliwal S, Ellis V. The effect of a fibre supplement compared to a healthy diet on body composition, lipids, glucose, insulin and other metabolic syndrome risk factors in overweight and obese individuals. British Journal of Nutrition 2011;105:90-100.

Pal S, Khossousi A, Binns C, Dhaliwal S, Radavelli-Bagatini S. The effects of 12-week psyllium fibre supplementation or healthy diet on blood pressure and arterial stiffness in overweight and obese individuals. British Journal of Nutrition 2012;107:725-34.

\section{Perez-Jiminez 2008 \{published data only\}}

Perez-Jimenez J, Serrano J, Tabernero M, Arranz S, DiazRubio ME, Garcia-Diz L, et al. Effects of grape antioxidant dietary fiber in cardiovascular disease risk factors. Nutrition 2008;24:646-53.

\section{Pins 2002 \{published data only\}}

Keenan JM, Pins JJ, Geleva D, Frazel C, O'Connor PJ, Cherney LM. Whole-grain oat cereal consumption reduces antihypertensive medication need: a cost analysis. Preventive Medicine in Managed Care 2002;3(1):9-17.

* Pins JJ, Geleva DRD, Keenan JM, Frazel C, O'Connor PJ, Cherney LM. Do whole-grain oat cereals reduce the need for antihypertensive medications and improve blood pressure control?. The Journal of Family Practice 2002;51(4):353-9.

\section{Reimer 2013 \{published data only\}}

Reimer RA, Yamaguchi H, Eller LK, Lyon MR, Gahler RJ, Kacinik V, et al. Changes in visceral adiposity and serum cholesterol with a novel viscous polysaccharide in Japanese adults with abdominal obesity. Obesity 2013;21:E379-87.

\section{Schlamovitz 1987 \{published data only\}}

Schlamowitz P, Halberg T, Warnoe O, Wilstrup F, Ryttig K. Treatment of mild to moderate hypertension with dietary fibre. Lancet 1987;2:622-3.

\section{Shimizu 2008 \{published data only\}}

Shimizu C, Kihara M, Aoe S, Araki S, Ito K, Hayashi K, et al. Effect of high beta-glucan barley on serum cholesterol concentrations and visceral fat area in Japanese men - A randomized, doubleblinded, placebo-controlled trial. Plant Foods for Human Nutrition 2008;63:21-5.

\section{Tighe 2010 Wheat \{published data only\}}

Tighe P, Duthie G, Brittenden J, Vaughan N, Mutch W, Simpson WG, et al. Effects of wheat and oat-based whole grain foods on serum lipoprotein size and distribution in overweight middle aged people: a randomised controlled trial. PLoS ONE 2013; Vol. 8.

* Tighe P, Duthie G, Vaughan N, Brittenden J, Simpson WG, Duthie $S$, et al. Effect of increased consumption of whole-grain foods on blood pressure and other cardiovascular risk markers in healthy middle-aged persons: a randomized controlled trial. American Journal of Clinical Nutrition 2010;92:733-40.

\section{Tighe 2010 Wheat+Oats \{published data only\}}

Tighe P, Duthie G, Brittenden J, Vaughan N, Mutch W, Simpson WG, et al. Effects of wheat and oat-based whole grain foods on serum lipoprotein size and distribution in overweight middle aged people: a randomised controlled trial. PLOS ONE 2013; Vol. 8.

* Tighe P, Duthie G, Vaughan N, Brittenden J, Simpson WG, Duthie $S$, et al. Effect of increased consumption of whole-grain foods on blood pressure and other cardiovascular risk markers in healthy middle-aged persons: a randomized controlled trial. American Journal of Clinical Nutrition 2010;92:733-40.

\section{References to studies excluded from this review}

Bays 2013 \{published data only\}

Bays HE, Evans JL, Maki KC, Evans M, Maquet V, Cooper R, et al. Chitin-glucan fiber effects on oxidized low-density lipoprotein: a randomized controlled trial. European Journal of Clinical Nutrition 2013;67:2-7.

\section{Davy 2002 \{published data only\}}

Davy BM, Davy KP, Ho RC, Beske SD, Davrath LR, Melby CL. High-fiber oat cereal compared with wheat cereal consumption favorably alters LDL-cholesterol subclass and particle numbers in middle-aged and older men. American Journal of Clinical Nutrition 2002;76:351-8.

\section{Dodson 1989 \{published data only\}}

Dodson PM, Stephenson J, Dodson LJ, Kurnik D, Kritzinger EE, Taylor KG, et al. Randomized blind controlled trial of a highfiber, low fat and low sodium dietary regimen in mild essentialhypertension. Journal of Human Hypertension 1989;3:197-202.

\section{King 2008 \{published data only\}}

King DE, Mainous AG, Egan BM, Woolson RF, Geesey ME. Effect of psyllium fiber supplementation on C-reactive protein: the trial to reduce inflammatory markers (TRIM). Annals of Family Medicine 2008;6:100-6.

\section{Liao 2007 \{published data only\}}

Liao FH, Shieh MJ, Chang NC, Chien YW. Chitosan supplementation lowers serum lipids and maintains normal calcium, magnesium, and iron status in hyperlipidemic patients. Nutrition Research 2007;27:146-51.

\section{Mee 1997 \{published data only\}}

Mee KA, Gee DL. Apple fiber and gum arabic lowers total and low-density lipoprotein cholesterol levels in men with mild hypercholesterolemia. Journal of the American Dietetic Association 1997;97:422-4.

\section{Ramprasath 2014 \{published data only\}}

Ramprasath VR, Jenkins DJA, Lamarche B, Kendall CWC, Faulkner D, Cermakova L, et al. Consumption of a dietary portfolio of cholesterol lowering foods improves blood lipids without affecting concentrations of fat soluble compounds. Nutrition Journal 2014;13:12. 
Reid 2002 \{published data only\}

Reid R, Fodor G, Lydon-Hassen K, D'Angelo MS, McCrea J, Bowlby M, et al. Dietary counselling for dyslipidemia in primary care: results of a randomized trial. Canadian Journal of Dietetic Practice and Research 2002;63:169-75.

Tapola 2008 \{published data only\}

Tapola NS, Lyyra ML, Kolehmainen RM, Sarkkinen ES, Schauss AG. Safety aspects and cholesterol-lowering efficacy of chitosan tablets. Journal of the American College of Nutrition 2008;27:22-30.

\section{References to studies awaiting assessment}

\section{Keenan 2002b \{published data only\}}

Keenan JM, Pins JJ, Geleva D, Frazel C, O'Connor PJ, Cherney LM. Whole-grain oat cereal consumption reduces antihypertensive medication need: a cost analysis. Preventive Medicine in Managed Care 2002;3(1):9-17.

\section{References to ongoing studies}

\section{Lambert 2014 \{published data only\}}

Lambert JE, Parnell JA, Han J, Sturzenegger T, Paul HA, Vogel $\mathrm{HJ}$, et al. Evaluation of yellow pea fibre supplementation on weight loss and the gut microbiota: a randomized controlled trial. BMC Gastroenterology 2014;14:69. [http:// www.biomedcentral.com/1471-230X/14/69]

\section{Additional references}

\section{Aburto 2013}

Aburto NJ, Ziolkovska A, Hooper L, Elliott P, Cappuccio FP, Meerpohl JJ. Effect of lower sodium intake on health: systematic review and meta-analyses. BMJ 2013;346:f1326.

\section{Ascherio 1996}

Ascherio A, Hennekens C, Willett WC, Sacks F, Rosner B, Manson J, et al. Prospective study of nutritional factors, blood pressure, and hypertension among US women. Hypertension 1996;27(5):1065-72.

\section{Begg 2007}

Begg S, Vos T, Barker B, Stevenson C, Stanley L, Lopez A. The burden of disease and injury in Australia 2003. Canberra: Australian Institute of Health and Welfare; 2007 May Vol. Cat. No. PHE 82.

\section{Berg 2003}

Berg A, Konig D, Deibert P, Grathwohl D, Berg A, Baumstark MW, et al. Effect of an oat bran enriched diet on the atherogenic lipid profile in patients with an increased coronary heart disease risk. A controlled randomized lifestyle intervention study. Annals of Nutrition and Metabolism 2003;47(6):306-11.

\section{Bliss 2011}

Bliss DZ, Savik K, Jung HJ, Whitebird R, Lowry A. Symptoms associated with dietary fiber supplementation over time in individuals with fecal incontinence. Nursing Research and Practice 2011;60(3 Suppl):S58-67.

\section{Bovet 2012}

Bovet P, Paccaud F. Cardiovascular disease and the changing face of global public health: a focus on low and middle income countries. Public Health Reviews 2012;33(2):397-415.

\section{British Heart Foundation 2014}

British Heart Foundation. Cardiovascular Disease 2014. http:// www.bhf.org.uk/heart-health/conditions/cardiovasculardisease.aspx (accessed January 2014).

\section{British Nutrition Foundation 2012}

British Nutrition Foundation. Dietary Fibre 2012. http:// www.nutrition.org.uk/nutritionscience/nutrients/dietary-fibre? start=4 (accessed January 2014).

\section{Brown 1999}

Brown L, Rosner B, Willett WW, Sacks FM. Cholesterol-lowering effects of dietary fiber: a meta-analysis. American Journal of Clinical Nutrition 1999;69(1):30-42.

\section{Buil-Cosiales 2014}

Buil-Cosiales P, Itziar Zazpe I, Toledo E, Corella D, SalasSalvadó J, Diez-Espino J, et al. Fiber intake and all-cause mortality in the Prevención con Dieta Mediterránea (PREDIMED) study. American Journal of Clinical Nutrition 2014;100(6):1498-507.

\section{Buttriss 2008}

Buttriss JL, Stokes CS. Dietary fibre and health: an overview. Nutrition Bulletin 2008;33:186-200.

\section{Dietitians of Canada 2012}

Dietitians of Canada. Food sources of soluble fiber. http://www.dietitians.ca/ getattachment/3bb6330f-0ab2-48fc-9d24-1303ad70003d/ Factsheet-Food-Sources-of-Soluble-Fibre.pdf.aspx (accessed 25 November 2013).

\section{Eastwood 1983}

Eastwood MA, Passmore R. Dietary Fiber. Lancet 1983;2:202-6.

\section{Eshak 2010}

Eshak ES, Iso H, Date C, Kikuchi S, Watanabe Y, Wada Y, et al. Dietary fiber intake is associated with reduced risk of mortality from cardiovascular disease among Japanese men and women. Journal of Nutrition 2010;140(8):1445-53.

\section{Follman 1992}

Follmann D, Elliott P, Suh I, Cutler J. Variance imputation for overviews of clinical trials with continuous response. Journal of Clinical Epidemiology 1992;45:769-73.

\section{Higgins 2003}

Higgins JPT, Thompson SG, Deeks JJ, Altman DG. Measuring inconsistency in meta-analyses. BMJ 2003;327(7414):557-60. 


\section{Higgins 2011a}

Higgins JPT, Altman DG, Sterne JAC (editors). Chapter 8: Assessing risk of bias in included studies. In: Higgins JPT, Green S (editors). Cochrane Handbook for Systematic Reviews of Interventions Version 5.1.0 (updated March 2011). The Cochrane Collaboration, 2011. Available from www.cochranehandbook.org.

\section{Higgins 2011b}

Higgins JPT, Deeks JJ, Altman DG (editors). Chapter 16: Special topics in statistics. In: Higgins JPT, Green S (editors), Cochrane Handbook for Systematic Reviews of Interventions Version 5.1.0 (updated March 2011). The Cochrane Collaboration, 2011. Available from www.cochrane-handbook.org.

\section{Hu 2014}

Hu T, Bazzano LA. The low-carbohydrate diet and cardiovascular risk factors: evidence from epidemiologic studies. Nutrition, Metabolism and Cardiovascular Diseases 2014;24(4):337-43.

\section{James 2003}

James SL, Muir JG, Curtis SL, Gibson PR. Dietary fibre: a roughage guide. Internal Medicine Journal 2003;33:291-6.

\section{Jenkins 2002}

Jenkins DJ, Kendall CW, Vuksan V, Vidgen E, Parker T, Faulkner D, et al. Soluble fiber intake at a dose approved by the US Food and Drug Administration for a claim of health benefits: serum lipid risk factors for cardiovascular disease assessed in a randomized controlled crossover trial. American Journal of Clinical Nutrition 2002;75(5):834-9.

\section{Keenan 2002}

Keenan JM, Pins JJ, Frazel C, Moran A, Turnquist L. Oat ingestion reduces systolic and diastolic blood pressure in patients with mild or borderline hypertension: a pilot trial. The Journal of Family Practice 2002;51(4):369.

\section{Kim 2014}

Kim Y, Je Y. Dietary fiber intake and total mortality: a metaanalysis of prospective cohort studies. American Journal of Epidemiology 2014;180:565-73.

\section{King 2012}

King DE, Mainous AG, Lambourne CA. Trends in dietary fiber intake in the United States, 1999-2008. Journal of the Academy of Nutrition and Dietetics 2012;112(5):642-8.

\section{Kokubo 2011}

Kokubo Y, Iso H, Saito I, Yamagishi K, Ishihara J, Inoue M, et al. Dietary fiber intake and risk of cardiovascular disease in the Japanese population: the Japan Public Health Centerbased study cohort. European Journal of Clinical Nutrition 2011;65(11):1233-41.

\section{Lattimer 2010}

Lattimer JM, Haub MD. Effects of dietary fiber and its components on metabolic health. Nutrients 2010;2(12):1266-89.

\section{Lefebvre 2011}

Lefebvre C, Manheimer E, Glanville J. Lefebvre C, Manheimer E, Glanville J. Chapter 6: Searching for studies. In: Higgins JPT, Green S (editors). Cochrane Handbook for Systematic Reviews of Interventions Version 5.1.0 (updated March 2011). The Cochrane Collaboration, 2011. Available from www.cochranehandbook.org.

\section{Lim 2012}

Lim SS, Vos T, Flaxman AD, Danaei G, Shibuya K, Adair-Rohani H, et al. A comparative risk assessment of burden of disease and injury attributable to 67 risk factors and risk factor clusters in 21 regions, 1990-2010: a systematic analysis for the Global Burden of Disease Study 2010. Lancet 2012;380(9859):2224-60.

\section{Liu 2002}

Liu S, Buring JE, Sesso HD, Rimm EB, Willett WC, Manson JE. A prospective study of dietary fiber intake and risk of cardiovascular disease among women. Journal of the American College of Cardiology 2002;39(1):49-56.

\section{Lunn 2007}

Lunn J, Buttriss JL. Carbohydrates and dietary fibre. Nutrition Bulletin 2007;32(1):21-64.

\section{Moher 2009}

Moher D, Liberati A, Tetzlaff J, Altman DG, The PRISMA Group (2009). Preferred Reporting Items for Systematic Reviews and Meta-Analyses: The PRISMA Statement. PLoS Medicine 2009;6(7):e1000097. [DOI: doi:10.1371/journal.pmed.1000097]

\section{Nakaji 2002}

Nakaji S, Sugawara K, Saito D, Yoshioka Y, MacAuley D, Bradley $\mathrm{T}$, et al. Trends in dietary fiber intake in Japan over the last century. European Journal of Nutrition 2002;41(5):222-7.

\section{$\mathrm{Ng} 1997$}

Ng TKW. Dietary fat and fibre intakes of Malaysian adults: issues and implications when 'western targets' are set as dietary goals. Malaysian Journal of Nutrition 1997;3:137-47.

\section{NHS 2012}

National Health Service. Atherosclerosis 2012. http:// www.nhs.uk/conditions/Atherosclerosis/Pages/ Introduction.aspx\#commentCountLink (accessed January 2014).

\section{NHS 2013}

National Health Service. Why is fibre important? 2013. http:// www.nhs.uk/chq/pages/1141.aspx?categoryid=51 (accessed January 2014).

\section{Nüesch 2010}

Nüesch E, Trelle S, Reichenbach S, Rutjes AW, Tschannen B, Altman DG, et al. Small study effects in meta-analyses of osteoarthritis trials: meta-epidemiological study. BMJ 2010;341:c3515.

\section{Oude 2010}

Oude Griep LM, Gelejinse JM, Kronhout D, Ocke MC, Verschuern WM. Raw and processed fruit and vegetable 
consumption and 10-year coronary heart disease incidence in a population-based cohort study in the Netherlands. PLOS ONE 2010;5:e13609.

\section{RevMan 2014 [Computer program]}

The Nordic Cochrane Centre, The Cochrane Collaboration. Review Manager (RevMan). Version 5.3. Copenhagen: The Nordic Cochrane Centre, The Cochrane Collaboration, 2014.

\section{Reyna-Villasmil 2007}

Reyna-Villasmil N, Bermudez-Pirela V, Mengual-Moreno E, Arias N, Cano-Ponce C, Leal-Gonzalez E, et al. Oat-derived beta-glucan significantly improves HDLC and diminishes LDLC and non-HDL cholesterol in overweight individuals with mild hypercholesterolemia. American Journal of Therapeutics 2007;14:203-12.

\section{Saltzman 2001}

Saltzman E, Das SK, Lichtenstein AH, Dallal GE, Corrales A, Schaefer EJ, et al. An oat-containing hypocaloric diet reduces systolic blood pressure and improves lipid profile beyond effects of weight loss in men and women. The Journal of Nutrition 2001;131:1465-70.

\section{Satija 2012}

Satija A, Hu FB. Cardiovascular benefits of dietary fiber. Current Atherosclerosis Reports 2012;14(6):505-14.

\section{Spagnoli 2007}

Spagnoli LG, Bonanno E, Sangiorgi G, Mauriello A. Role of inflammation in atherosclerosis. Journal of Nuclear Medicine 2007;48(11):1800-15.

\section{Sterne 2000}

Sterne JA, Gavaghan D, Egger M. Publication and related bias in meta-analysis: power of statistical tests and prevalence in the literature. Journal of Clinical Epidemiology 2000;53:1119-29.

\section{Sterne 2001}

Sterne JA, Egger M, Smith GD. Systematic reviews in health care: investigating and dealing with publication and other biases in meta-analysis. BMJ 2001;323:101-5.

\section{Sterne 2011}

Sterne JAC, Egger M, Moher D (editors). Chapter 10: Addressing reporting biases. In: Higgins JPT, Green S (editors). Cochrane Handbook for Systematic Reviews of Intervention. Version 5.1.0 (updated March 2011). The Cochrane Collaboration, 2011. Available from www.cochrane-handbook.org.

\section{Streppel 2005}

Streppel MT, Arends LR, Van 't Veer P, Grobbee DE, Geleijnse JM. Dietary fiber and blood pressure: a meta-analysis of randomized placebo-controlled trials. Archives of Internal Medicine 2005;165:150-6.

\section{Threapleton 2013}

Threapleton DE, Greenwood DC, Evans CEL, Cleghorn CL, Nykjaer C, Woodhead C, et al. Dietary fibre intake and risk of cardiovascular disease: systematic review and meta-analysis. BMJ 2013;347:f6879.

\section{Vuksan 2008}

Vuksan V, Jenkins AL, Jenkins DJ, Rogovik AL, Sievenpiper JL, Jovanovski E. Using cereal to increase dietary fiber intake to the recommended level and the effect of fiber on bowel function in healthy persons consuming North American diets. American Journal of Clinical Nutrition 2008;88(5):1256-62.

\section{Wallström 2012}

Wallström P, Sonestedt E, Hlebowicz J, Ericson U, Drake I, Persson $\mathrm{M}$, et al. Dietary fiber and saturated fat intake associations with cardiovascular disease differ by sex in the Malmö Diet and Cancer Cohort: a prospective study. PLoS One 2012;7(2):e31637.

\section{Whitehead 2014}

Whitehead A, Beck EJ, Tosh S, Wolever TMS. Cholesterollowering effects of oat beta-glucan: A meta-analysis of randomized controlled trials. American Journal of Clinical Nutrition. 2014;100:1413-21.

\section{WHO 1990}

World Health Organization. Diet, nutrition, and the prevention of chronic diseases. Report of a WHO Study Group, WHO Technical Report Series 797. Geneva: World Health Organization, 1990.

\section{WHO 2013}

World Health Organization. Cardiovascular diseases (CVDs) Fact Sheet Number 317. March 2013. http://www.who.int/ mediacentre/factsheets/fs317/en/index.html (accessed January 2014).

\section{Ye 2012}

Ye EQ, Chacko SA, Chou EL, Kugizaki M, Liu S. Greater wholegrain intake is associated with lower risk of type 2 diabetes, cardiovascular disease, and weight gain. Journal of Nutrition 2012;142(7):1304-13.

* Indicates the major publication for the study

\section{CHARACTERISTICS OF STUDIES}

Characteristics of included studies [ordered by study ID]

Aro 1984 
Aro 1984 (Continued)

Design: individual randomisation, cross-over RCT

Dates: not reported

Intervention duration: 12 weeks

Participants N: 14 randomised (7 in each group)

Inclusion criteria: hypercholesterolaemia without marked hypertriglyceridaemia (serum cholesterol > $7.8 \mathrm{mmol} / \mathrm{L}$ and serum trig $<30 \mathrm{mmol} / \mathrm{L}$ ), aged 30 years to 64 years

Exclusion criteria: Thyroid dysfunction, renal or liver diease, diabetes, over $120 \%$ of ideal body weight

Age (years): 51 years (all participants)

Sex (\% men): $100 \%$

Ethnicity: not reported

Cardiovascular risk status: mean (SD)

$B M I\left(k g / m^{2}\right):$ not reported

Total cholesterol (mmol/L): intervention: 8.59 (0.7); control: 8.57 (0.8)

HDL cholesterol (mmol/L): intervention: 1.49 (0.2); control: 1.47 (0.2)

LDL cholesterol (mmol/L): intervention: 5.98 (0.7); control: 5.81 (0.6)

Triglycerides (mmol/L) intervention: 1.64 (0.4); control: $1.88(0.4)$

Blood pressure ( $\mathbf{m m H g})$ : not reported

Interventions

Type: fibre supplements

Description: $15 \mathrm{~g}$ guar gum (soluble fibre), granulated guar gum preparation, $5 \mathrm{~g}$ doses at beginning of three main meals immediately after mixing with $200 \mathrm{ml}$ of fluid. Control consumed $15 \mathrm{~g}$ placebo preparation consisting of wheat flour

Outcomes Lipid levels, adverse events

Notes

\section{Risk of bias}

\begin{tabular}{lll}
\hline Bias & Authors' judgement & Support for judgement \\
\hline $\begin{array}{l}\text { Random sequence genera- } \\
\text { tion (selection bias) }\end{array}$ & Unclear risk & No details reported \\
\hline $\begin{array}{l}\text { Allocation concealment } \\
\text { (selection bias) }\end{array}$ & Unclear risk & No details reported \\
\hline $\begin{array}{l}\text { Blinding of participants } \\
\text { and personnel (perfor- } \\
\text { mance bias) } \\
\text { All outcomes }\end{array}$ & Low risk & States double blind with placebo \\
\hline
\end{tabular}


Aro 1984 (Continued)

Incomplete outcome data Low risk No missing data
(attrition bias)

All outcomes

Selective reporting (re- Unclear risk All outcomes stated were reported but unable to fully judge porting bias)

\begin{tabular}{|c|c|c|}
\hline Other bias & Unclear risk & Not enough information to judge \\
\hline
\end{tabular}

Birketvedt 2002

Setting: Norway, setting not reported
Design: individual randomisation, parallel group
Dates: not reported
Intervention duration: three months

\footnotetext{
Participants N: 62 (intervention 31; control 31). Baseline characteristics and results based on Intervention 25 and control 27

Inclusion criteria: overweight and obese, 22 years to 66 years

Exclusion criteria: not stated

Age (years): mean (SD); intervention: 47 (11); control: 44 (11)

Sex (\% men): intervention: $36 \%$; control: $44 \%$

Ethnicity: not reported

Cardiovascular risk status: mean (SD)

BMI ( $\mathbf{k g} / \mathbf{m}^{2}$ ): intervention: 33.9 (3.4); control: 35.0 (5.4)

Total cholesterol (mmol/L): intervention: 6.6 (1.3); control: 6.2 (1.3)

HDL cholesterol (mmol/L): intervention: 1.3 (0.5); control: $1.2(0.4)$

LDL cholesterol (mmol/L): intervention: 4.4 (1.0); control: 4.1 (1.4)

Triglycerides (mmol/L): intervention: 1.8 (0.8); control: 2.4 (2.2)

Blood pressure (mmHg): not reported
}

Interventions Type: fibre supplements

Description: extract of northern white kidney bean mixed with extract of locust bean gum (soluble and insoluble fibre). Two capsules three times each day at main meals. Control group were given placebo capsules, same regimen

\begin{tabular}{ll}
\hline Outcomes & Lipid levels, adverse events \\
\hline Notes & \\
\hline Risk of bias & Authors' judgement Support for judgement \\
\hline Bias & Sulgent \\
\hline
\end{tabular}


Birketvedt 2002 (Continued)

Random sequence genera- Unclear risk $\quad$ No details reported
tion (selection bias)

\begin{tabular}{lll}
\hline $\begin{array}{l}\text { Allocation concealment } \\
\text { (selection bias) }\end{array}$ & Unclear risk & No details reported
\end{tabular}

Blinding of participants Unclear risk $\quad$ No details reported
and personnel (perfor-
mance bias)

\begin{tabular}{lll}
\hline $\begin{array}{l}\text { Blinding of outcome as- } \\
\text { sessment (detection bias) } \\
\text { All outcomes }\end{array}$ & Unclear risk & No details reported \\
\hline $\begin{array}{l}\text { Incomplete outcome data } \\
\begin{array}{l}\text { (attrition bias) } \\
\text { All outcomes }\end{array}\end{array}$ & Unclear risk & Numbers and reasons given but no ITT \\
\hline $\begin{array}{l}\text { Selective reporting (re- } \\
\text { porting bias) }\end{array}$ & Unclear risk & Not enough information to judge \\
\hline Other bias & Unclear risk & Not enough information to judge \\
\hline
\end{tabular}

\section{Cicero 2010 GuarGum}

\begin{tabular}{ll}
\hline Methods & Setting: Italy, setting not reported \\
Design: individual randomisation, parallel group \\
Dates: not reported \\
Intervention duration: six months
\end{tabular}

Participants

$\mathrm{N}$ : 137 randomised (intervention $1, \mathrm{~N}=46$, intervention $2, \mathrm{~N}=46$, control, $\mathrm{N}=45$ )

Inclusion criteria: metabolic syndrome, not taking antihypercholesterolaemic or antidiabetic treatments, or stabilised antihypercholesterol or antidiabetic treatment for at least six months. Any three of: waist circumference > $102 \mathrm{~cm}$ men and $>88 \mathrm{~cm}$ women; TG $1.70 \mathrm{mmol} / \mathrm{L}$; HDL-C < $1.03 \mathrm{mmol} / \mathrm{L}$ men, < 1.29 women; SBP $130 / 85 \mathrm{mmHg}$ or stabilised antihypertensive treatment for at least six months, FPG $6.1 \mathrm{mmol} / \mathrm{L}$.

Exclusion criteria: severe hyperlipoproteinemias, uncontrolled diabetes, active treatments with anticoagulant, anticancer, antiretroviral drugs, previous CVD events

Age (years): mean (SD); intervention 1: 58.4 (2.5); intervention 2: 57.9 (1.8); control: 57.2 (2.1)

Sex (\% men): not reported

Ethnicity: $100 \%$ Caucasian

Cardiovascular risk status: mean (SD)

BMI (kg/m²): intervention 1: 28.8 (1.5); intervention 2: 28.6 (1.3); control: 28.5 (1.6)

Total cholesterol (mmol/L): intervention 1: 4.8 (0.6); intervention 2: 4.9 (0.6); control: 4.8 (0.7)

HDL cholesterol (mmol/L): intervention 1: 1.10 (0.13); intervention 2: 1.2 (0.1); control: 1.1 (0.1) 
Cicero 2010 GuarGum (Continued)

LDL cholesterol (mmol/L): intervention 1: 2.9 (0.3); intervention 2: 3.0 (0.4); control: 3.0 (0.3)

Triglycerides (mmol/L): intervention 1: 1.8 (0.3); intervention 2: 1.7 (0.2); control: 1.7 (0.3)

Blood pressure (mmHg): intervention 1: SBP 131.4 (4.2); DBP 84.6 (4.4); intervention 2: 131.6 (4.0); DBP 85.2 (3.6); control: SBP 131.0 (3.7); DBP 84.5 (3.9)

\begin{tabular}{ll}
\hline Interventions & Type: fibre supplement \\
& Description: intervention 1: soluble psyllium husk powder (soluble fibre); intervention 2: partially hy- \\
& drolysed guar gum (soluble fibre). Both $3.5 \mathrm{~g}$ twice daily 20 minutes before two main meals, received a \\
box containing a 60 -day supply. Control group advised to follow the AHA Step 2 diet. All participants re- \\
ceived dietary advice
\end{tabular}

Outcomes BP, lipid levels, adverse events

\section{Notes}

\section{Risk of bias}

\begin{tabular}{|c|c|c|}
\hline Bias & Authors' judgement & Support for judgement \\
\hline $\begin{array}{l}\text { Random sequence genera- } \\
\text { tion (selection bias) }\end{array}$ & Low risk & Randomisation code by study statistician opening a previously prepared letter \\
\hline $\begin{array}{l}\text { Allocation concealment } \\
\text { (selection bias) }\end{array}$ & Low risk & Code only broken after database lock \\
\hline $\begin{array}{l}\text { Blinding of participants } \\
\text { and personnel (perfor- } \\
\text { mance bias) } \\
\text { All outcomes }\end{array}$ & High risk & $\begin{array}{l}\text { Not possible as two fibres have different colour and flavour and the compari- } \\
\text { son group was dietary advice not placebo }\end{array}$ \\
\hline $\begin{array}{l}\text { Blinding of outcome as- } \\
\text { sessment (detection bias) } \\
\text { All outcomes }\end{array}$ & Unclear risk & No details provided \\
\hline $\begin{array}{l}\text { Incomplete outcome data } \\
\text { (attrition bias) } \\
\text { All outcomes }\end{array}$ & Unclear risk & ITT analysis but no other details \\
\hline $\begin{array}{l}\text { Selective reporting (re- } \\
\text { porting bias) }\end{array}$ & Unclear risk & All outcomes stated were reported but unable to fully judge \\
\hline Other bias & Unclear risk & Not enough information to judge \\
\hline
\end{tabular}

Cicero 2010 Pysllium

$\begin{array}{ll}\text { Methods } & \text { Please see details as above. This is the same trial with two relevant intervention arms for fibre supple- } \\ \text { ment. intervention 1: soluble psyllium husk powder (Cicero } 2010 \text { Pysllium); intervention 2: partially hy- } \\ \text { drolysed guar gum (as above - Cicero } 2010 \text { GuarGum). Each arm was entered into the analysis separate- } \\ \text { ly. }\end{array}$

\footnotetext{
Participants
} 
Cicero 2010 Pysllium (Continued)

Outcomes

\section{Notes}

\section{Risk of bias}

\begin{tabular}{lll}
\hline Bias & Authors' judgement & Support for judgement \\
\hline $\begin{array}{l}\text { Random sequence genera- } \\
\text { tion (selection bias) }\end{array}$ & Low risk & see previous \\
\hline $\begin{array}{l}\text { Allocation concealment } \\
\text { (selection bias) }\end{array}$ & Low risk & see previous \\
\hline $\begin{array}{l}\text { Blinding of participants } \\
\text { and personnel (perfor- } \\
\text { mance bias) } \\
\text { All outcomes }\end{array}$ & High risk & see previous \\
\hline $\begin{array}{l}\text { Blinding of outcome as- } \\
\text { sessment (detection bias) }\end{array}$ & Unclear risk & see previous \\
All outcomes & & \\
\hline $\begin{array}{l}\text { Incomplete outcome data } \\
\text { (attrition bias) } \\
\text { All outcomes }\end{array}$ & Unclear risk & see previous \\
\hline $\begin{array}{l}\text { Selective reporting (re- } \\
\text { porting bias) }\end{array}$ & Unclear risk & see previous \\
\hline \begin{tabular}{l} 
Other bias \\
\hline
\end{tabular} & Unclear risk & see previous \\
\hline
\end{tabular}

\section{Forcheron 2007}

\begin{tabular}{|c|c|}
\hline Methods & $\begin{array}{l}\text { Setting: France, setting not stated } \\
\text { Design: individual randomisation, parallel design } \\
\text { Dates: not reported } \\
\text { Intervention duration: six months }\end{array}$ \\
\hline Participants & $\begin{array}{l}\text { N: } 20 \text { randomised (10 to each group). Baseline characteristics and results based on intervention N=9, } \\
\text { control } N=8 \\
\text { Inclusion criteria: Healthy, no history of diabetes, obesity or dyslipidaemia or taking any medications } \\
\text { Exclusion criteria: unusual dietary habits or intensive physical activity } \\
\text { Age (years): mean (SD); intervention: } 29 \text { (4); control: } 34 \text { (2) } \\
\text { Sex (\% men): intervention: } 37.5 \% \text {; control: } 33.3 \% \\
\text { Ethnicity: not reported } \\
\text { Cardiovascular risk status: mean (SD) } \\
\text { BMI ( } \mathbf{k g} / \mathbf{m}^{2} \text { ): not reported }\end{array}$ \\
\hline
\end{tabular}


Total cholesterol (mmol/L): intervention: 4.48 (0.16); control: $3.91(0.33)$

HDL cholesterol (mmol/L): intervention: 1.29 (0.09); control: 1.03 (0.09)

LDL cholesterol (mmol/L): intervention: 2.88 (0.13); control: 2.55 (0.33)

Triglycerides (mmol/L): intervention: 0.71 (0.07); control: $0.78(0.16)$

Blood pressure $(\mathbf{m m H g})$ : not reported

Interventions Type: fibre supplements

Description: Fructans $5 \mathrm{~g}$ (soluble fibre) before breakfast and evening meal as powder dissolved in water, requested to avoid food rich in inulin or oligofructase, and to continue with their usual physical activity. Control participants had $5 \mathrm{~g}$ twice daily powder dissolved in water as a placebo. Same advice.

Outcomes Lipid levels, adverse events

Notes

\section{Risk of bias}

\begin{tabular}{|c|c|c|}
\hline Bias & Authors' judgement & Support for judgement \\
\hline $\begin{array}{l}\text { Random sequence genera- } \\
\text { tion (selection bias) }\end{array}$ & Unclear risk & No details reported \\
\hline $\begin{array}{l}\text { Allocation concealment } \\
\text { (selection bias) }\end{array}$ & Unclear risk & No details reported \\
\hline $\begin{array}{l}\text { Blinding of participants } \\
\text { and personnel (perfor- } \\
\text { mance bias) } \\
\text { All outcomes }\end{array}$ & Low risk & States double blind with placebo \\
\hline $\begin{array}{l}\text { Blinding of outcome as- } \\
\text { sessment (detection bias) } \\
\text { All outcomes }\end{array}$ & Unclear risk & No details reported \\
\hline $\begin{array}{l}\text { Incomplete outcome data } \\
\text { (attrition bias) } \\
\text { All outcomes }\end{array}$ & High risk & Not reported which groups or reasons for drop-outs \\
\hline $\begin{array}{l}\text { Selective reporting (re- } \\
\text { porting bias) }\end{array}$ & Unclear risk & All outcomes stated are reported but unable to fully judge \\
\hline Other bias & Unclear risk & No details reported \\
\hline
\end{tabular}

\section{Gato 2013}

Methods

Setting: Japan, setting not reported

Design: individual randomisation, parallel group

Dates: not reported

Intervention duration: 12 weeks 
Gato 2013 (Continued)
Participants
$\mathrm{N}: 27$ randomised (intervention $\mathrm{N}=13$, control $\mathrm{N}=14$ )
Inclusion criteria: aged 25 years to 51 years, plasma cholesterol level $180-259 \mathrm{mg} / \mathrm{dl}$
Exclusion criteria: not stated
Age (years): mean (SD); intervention: 36.4 (1.8); control: 36.6 (1.8)
Sex ( $\%$ men): intervention: $44 \%$; control $40 \%$
Ethnicity: not reported
Cardiovascular risk status: mean (SD)
$B M I\left(k g / m^{2}\right):$ not reported
Total cholesterol (mmol/L): not reported
HDL cholesterol (mmol/L): not reported
LDL cholesterol (mmol/L): not reported
Triglycerides ( $\mathrm{mmol} / \mathrm{L})$ : not reported
Blood pressure ( $\mathbf{m m H g})$ : not reported

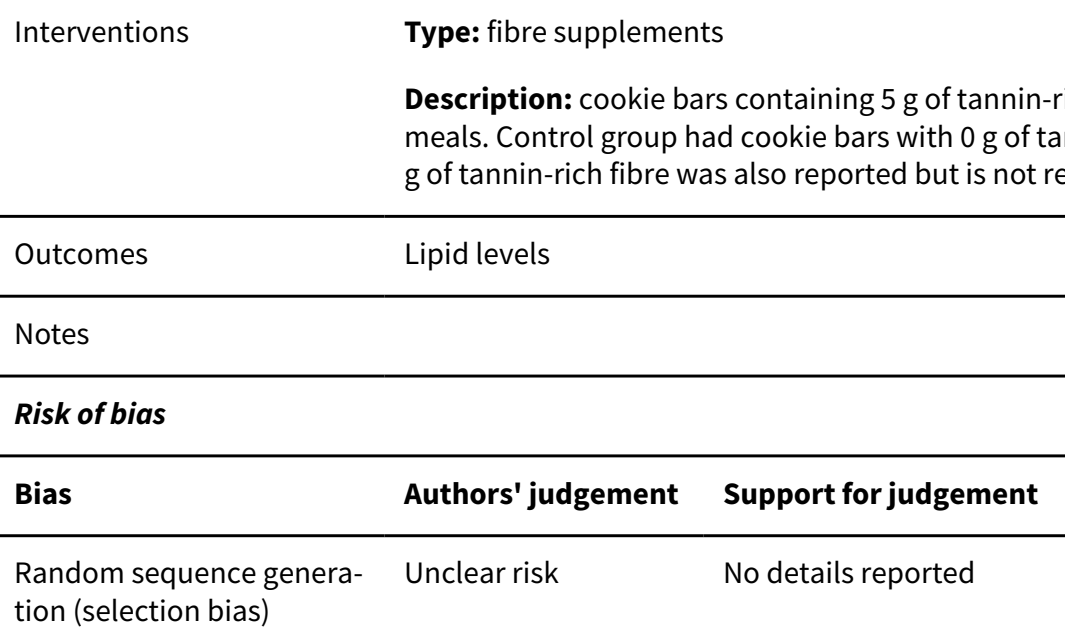

\begin{tabular}{lll}
\hline $\begin{array}{l}\text { Allocation concealment } \\
\text { (selection bias) }\end{array}$ & Unclear risk & No details reported \\
\hline $\begin{array}{l}\text { Blinding of participants } \\
\text { and personnel (perfor- } \\
\text { mance bias) }\end{array}$ & Low risk & States double blind and placebo \\
All outcomes & \\
\hline
\end{tabular}

Blinding of outcome as- Unclear risk No details reported

sessment (detection bias)

All outcomes

\begin{tabular}{l}
\hline Incomplete outcome data Low risk $\quad$ All participants reported \\
(attrition bias) \\
All outcomes
\end{tabular}

Selective reporting (re- High risk $\quad$ No data reported
porting bias)


Gato 2013 (Continued)

Other bias Unclear risk Not enough detail to judge

Hashizume 2012

\begin{tabular}{ll} 
Methods & Setting: Japan, setting not reported \\
& Design: individual randomisation, parallel group \\
& Dates: not reported \\
Intervention duration: 12 weeks & N: 30 randomised (15 to each group). \\
\hline Inclusion criteria: mildly obese, exhibit visceral fat obesity and satisfy two of three from: dyslipi- \\
daemia, impaired glucose tolerance but no diabetes, high BP
\end{tabular}

Exclusion criteria: DM, medical treatment with fibrates, thiazolidines or anion-exchange resins.

Age (years): mean (SD); intervention: 60.1 (8.9); control: 61.2 (11.6)

Sex (\% men): intervention: $60 \%$; control: $73.3 \%$

Ethnicity: not reported

Cardiovascular risk status: mean (SD)

BMI ( $\left.\mathbf{k g} / \mathbf{m}^{2}\right)$ : intervention: 28.1 (2.3); control: 26.8 (2.9)

Total cholesterol (mmol/L): intervention: 5.74 (0.88); control: 5.64 (0.87)

HDL cholesterol (mmol/L): intervention: 1.27 (0.24); control: 1.25 (0.33)

LDL cholesterol (mmol/L): intervention: 3.81 (0.98); control: 3.77 (0.88)

Triglycerides (mmol/L): intervention: 2.43 (0.46); control: $2.24(0.50)$

Blood pressure ( $\mathbf{m m H g})$ : not reported

Interventions Type: provision of foods high in fibre

Description: unsweetened blended tea drink containing $9 \mathrm{~g}$ of resistant maltodextrins (RMD) (soluble fibre) in $280 \mathrm{ml}$. Other ingredients stated. Three bottles daily, one per meal time. Control: placebo tea, consumption as intervention group, nutrient contents same except fibre as placebo tea. Both groups not to change lifestyles with regards to diet, exercise or medication

Outcomes BP, lipid levels, adverse events

Notes

\section{Risk of bias}

\begin{tabular}{lll}
\hline Bias & Authors' judgement & Support for judgement \\
\hline $\begin{array}{l}\text { Random sequence genera- } \\
\text { tion (selection bias) }\end{array}$ & Unclear risk & No details reported \\
\hline $\begin{array}{l}\text { Allocation concealment } \\
\text { (selection bias) }\end{array}$ & Unclear risk & No details reported \\
\hline
\end{tabular}


Hashizume 2012 (Continued)

Blinding of participants Low risk States double blind and placebo and personnel (performance bias)

All outcomes

\begin{tabular}{lll}
\hline $\begin{array}{l}\text { Blinding of outcome as- } \\
\text { sessment (detection bias) } \\
\text { All outcomes }\end{array}$ & Unclear risk & No details reported \\
\hline $\begin{array}{l}\text { Incomplete outcome data } \\
\begin{array}{l}\text { (attrition bias) } \\
\text { All outcomes }\end{array}\end{array}$ & Unclear risk & No details reported \\
\hline $\begin{array}{l}\text { Selective reporting (re- } \\
\text { porting bias) }\end{array}$ & Unclear risk & All outcomes stated were reported but unable to fully judge \\
\hline Other bias & Unclear risk & Not enough information to judge \\
\hline
\end{tabular}

Haskell 1992

Methods
Setting: USA, setting not reported
Design: individual randomisation, parallel group
Dates: not reported
Intervention duration: 12 weeks
$\begin{aligned} & \text { N: } 62 \text { randomised (intervention } \mathrm{N}=32 \text {, control } \mathrm{N}=30 \text { ). Baseline characteristics and results based on in- } \\ & \text { tervention } \mathrm{N}=29 \text {, control } \mathrm{N}=29 \\ & \text { Inclusion criteria: aged } 20 \text { years to } 75 \text { years, plasma cholesterol }>5.17 \text { mmol/L, plasma triglycerides } \\ & \text { Participants } 3.95 \text { mmol/L, not on lipid lowering medication, dietary fibre supplementation, no history of gastroin- } \\ & \text { testinal disease, fasting blood glucose }<6.6 \text { mmol/L, normal liver function tests, no history or evidence } \\ & \text { of any disease that may influence lipoprotein metabolism, }<130 \% \text { of ideal body weight, antihyperten- } \\ & \text { sive medications, oral contraceptions, oestrogen replacement if on a stable dose for at least six months } \\ & \text { and no plans to change. }\end{aligned}$

Exclusion criteria: as above

Age (years): not reported

Sex (\% men): not reported

Ethnicity: not reported

Cardiovascular risk status: mean (SD)

$B M I\left(k g / m^{2}\right):$ not reported

Total cholesterol (mmol/L): intervention: 5.97 (0.82); control: 6.05 (0.47)

HDL cholesterol (mmol/L): intervention: 1.47 (0.47); control: 1.54 (0.44)

LDL cholesterol (mmol/L): intervention: 4.01 (0.67); control: 3.86 (0.57)

Triglycerides (mmol/L): intervention: 1.36 (0.61); control: 1.44 (0.64)

Blood pressure ( $\mathbf{m m H g})$ : not reported 
Haskell 1992 (Continued)

Interventions
Type: fibre supplements

Description: water soluble dietary fibre - $17 \mathrm{~g} /$ day from a mixture of dietary sources (major component being $56 \%$ acacia gum, the remaining psyllium husk and guar gum) (soluble fibre). Control given a placebo powder with only the carbohydrate fraction present, with equal calories
Outcomes
Lipid levels, adverse events

Notes

\section{Risk of bias}

\begin{tabular}{|c|c|c|}
\hline Bias & Authors' judgement & Support for judgement \\
\hline $\begin{array}{l}\text { Random sequence genera- } \\
\text { tion (selection bias) }\end{array}$ & Unclear risk & No details reported \\
\hline $\begin{array}{l}\text { Allocation concealment } \\
\text { (selection bias) }\end{array}$ & Unclear risk & No details reported \\
\hline $\begin{array}{l}\text { Blinding of participants } \\
\text { and personnel (perfor- } \\
\text { mance bias) } \\
\text { All outcomes }\end{array}$ & Low risk & States double blind with placebo \\
\hline $\begin{array}{l}\text { Blinding of outcome as- } \\
\text { sessment (detection bias) } \\
\text { All outcomes }\end{array}$ & Unclear risk & No details reported \\
\hline $\begin{array}{l}\text { Incomplete outcome data } \\
\text { (attrition bias) } \\
\text { All outcomes }\end{array}$ & Unclear risk & Numbers given but no reasons \\
\hline $\begin{array}{l}\text { Selective reporting (re- } \\
\text { porting bias) }\end{array}$ & Unclear risk & Not enough information to judge \\
\hline Other bias & Unclear risk & Not enough information to judge \\
\hline
\end{tabular}

He 2004

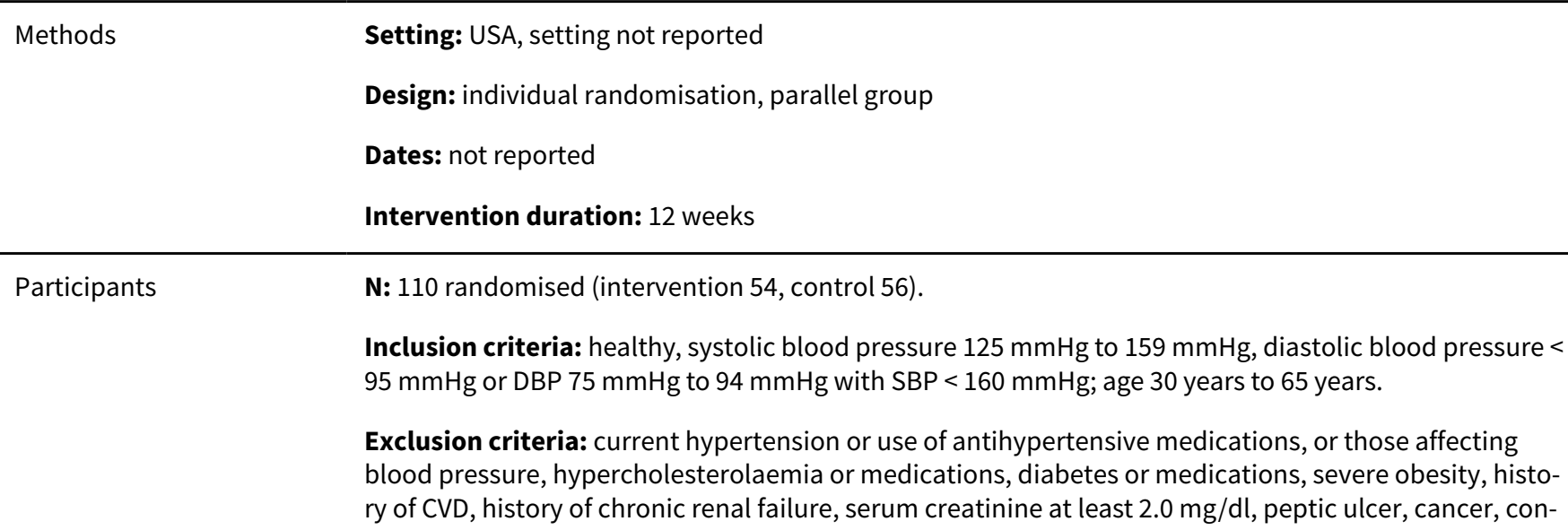


He 2004 (Continued)

sumption of more than 21 alcoholic drinks per week, vegetarian, current use of fibre supplements, prior assignment to intervention in BP trial, poor compliance during run-in phase.

Age (years): mean (SD); intervention: 49.7 (8.2); control: 46.1 (8.6)

Sex (\% men): intervention: $40.7 \%$; control: $39.3 \%$

Ethnicity: intervention: 57.9\% African American; control: 53.6\% African American

Cardiovascular risk status: mean (SD)

BMI ( $\left.\mathbf{k g} / \mathbf{m}^{2}\right)$ : intervention: 28.5 (5.0); control: 29.3 (4.1)

Total cholesterol (mmol/L): intervention: 5.12 (0.95); control: 5.18 (0.86)

HDL cholesterol (mmol/L): intervention: 1.34 (0.43); control: 1.23 (0.36)

LDL cholesterol (mmol/L): intervention: 3.19 (0.86); control: 3.32 (0.82)

Triglycerides (mmol/L): intervention: 1.27 (0.73); control: 1.37 (0.63)

Blood pressure (mmHg): intervention: SBP 129.8 (10.2); DBP 81.1 (6.4); control: SBP 126.4 (10.0); DBP $79.6(6.6)$

Interventions Type: provision of foods high in fibre

Description: daily serving of approximately $60 \mathrm{~g}$ of Quaker Oat Bran Concentrate as a muffin and $84 \mathrm{~g}$ of Quaker Oatmeal Squares (soluble fibre). Reduction in other high carbohydrate food intake. Remain at usual level of activity, alcohol intake and dietary sodium intake. Control group had $93 \mathrm{~g}$ of refined wheat as a muffin and $42 \mathrm{~g}$ of Kellogg's Corn Flakes
Outcomes
BP, lipid levels, adverse events

\section{Notes}

\section{Risk of bias}

\begin{tabular}{|c|c|c|}
\hline Bias & Authors' judgement & Support for judgement \\
\hline $\begin{array}{l}\text { Random sequence genera- } \\
\text { tion (selection bias) }\end{array}$ & Low risk & Stratified by age and gender, block sizes reported \\
\hline $\begin{array}{l}\text { Allocation concealment } \\
\text { (selection bias) }\end{array}$ & Low risk & Opaque envelopes only opened after confirmed eligibility \\
\hline $\begin{array}{l}\text { Blinding of participants } \\
\text { and personnel (perfor- } \\
\text { mance bias) } \\
\text { All outcomes }\end{array}$ & Low risk & States double blind and cereals blinded \\
\hline $\begin{array}{l}\text { Blinding of outcome as- } \\
\text { sessment (detection bias) } \\
\text { All outcomes }\end{array}$ & Low risk & Technicians masked to assignment \\
\hline $\begin{array}{l}\text { Incomplete outcome data } \\
\text { (attrition bias) } \\
\text { All outcomes }\end{array}$ & Unclear risk & Reported numbers but not reasons \\
\hline $\begin{array}{l}\text { Selective reporting (re- } \\
\text { porting bias) }\end{array}$ & Unclear risk & All outcomes stated were reported but unable to fully judge \\
\hline
\end{tabular}


He 2004 (Continued)

Other bias Unclear risk Not enough information to judge

Hernandez-Gonzalez 2010

Setting: Mexico, setting not reported
Design: individual randomisation, parallel group
Dates: not reported
Intervention duration: three months

Participants

N: 12 randomised (six in each group)

Inclusion criteria: nonsmokers, stable body weight, BP less than $130 / 80 \mathrm{mmHg}$, not using medication known to affect metabolism, BMI $30 \mathrm{~kg} / \mathrm{m}^{2}$ to $40 \mathrm{~kg} / \mathrm{m}^{2}, 30$ years to 50 years old

Exclusion criteria: not reported

Age (years): mean (SD); intervention: 41.6 (6.3); control: 42.6 (5.6)

Sex (\% men): intervention 50\%; control $50 \%$

Ethnicity: not reported

Cardiovascular risk status: mean (SD)

BMI (kg/m²): intervention: 34.3 (2.7); control: 32.7 (1.7)

Total cholesterol (mmol/L): intervention: 4.2 (1.0); control: 4.7 (0.8)

HDL cholesterol (mmol/L): intervention: 0.9 (0.1); control: 0.9 (0.2)

LDL cholesterol (mmol/L): intervention: 2.7 (0.7); control: 2.8 (0.7)

Triglycerides (mmol/L): intervention: 2.4 (0.9); control: 2.2 (0.3)

Blood pressure (mm Hg): not reported

Type: fibre supplements
Description: chitosam (soluble fibre) $(750 \mathrm{mg}$, three times daily) 30 minutes before meals. All partici-
pants received general recommendations about their medical nutritional therapy and were instructed
to not modify their usual forms of exercise. Control group received a placebo in the same pharmacolog-
ical presentation as the intervention

\begin{tabular}{lll}
\hline Outcomes & Lipid levels \\
\hline Notes & \\
\hline Risk of bias & Authors' judgement & Support for judgement \\
\hline Bias & Unclear risk & No details reported \\
\hline $\begin{array}{l}\text { Random sequence genera- } \\
\text { tion (selection bias) }\end{array}$ & \\
\hline $\begin{array}{l}\text { Allocation concealment } \\
\text { (selection bias) }\end{array}$ & Unclear risk & No details reported \\
\hline
\end{tabular}


Hernandez-Gonzalez 2010 (Continued)

Blinding of participants Low risk States double blind
and personnel (perfor-
mance bias)
All outcomes

All outcomes

$\begin{array}{lll}\text { Blinding of outcome as- } & \text { Unclear risk } & \text { No details reported } \\ \text { sessment (detection bias) } & \end{array}$

All outcomes

Incomplete outcome data Unclear risk Not stated

(attrition bias)

All outcomes

\begin{tabular}{lll}
\hline $\begin{array}{l}\text { Selective reporting (re- } \\
\text { porting bias) }\end{array}$ & Unclear risk & Not enough information to judge \\
\hline Other bias & Unclear risk & Not enough information to judge \\
\hline
\end{tabular}

Hu 2013

\begin{tabular}{ll}
\hline Methods & Setting: China, setting not reported \\
Design: individual randomisation, parallel groups \\
Dates: not reported \\
Intervention duration: 12 weeks
\end{tabular}

Participants

$\mathbf{N}: 39$ randomised (intervention, $\mathrm{N}=22$; control, $\mathrm{N}=17$ )

Inclusion criteria: overweight and obese. Generally healthy adults aged 19 years to 39 years with BMI 23 to 35 .

Exclusion criteria: people taking any drugs, botanicals, or nutraceutical known to influence body weight or blood pressure, taking steroids and other agents that may influence lipid metabolism were excluded. Significant history of eating disorders, smoking and drinking, strenuous exercise to lose weight, hyperlipidaemia, hyperglycaemia, diabetes mellitus, cardiovascular disease, major systemic diseases, gastrointestinal problems, liver and renal failure.

Age (years): mean (SD) intervention: 24.7 (4.7); control: 21.2 (1.7)

Sex (\% men): intervention: $47 \%$; control: $41 \%$

Ethnicity: not reported

Cardiovascular risk status: mean (SD)

BMI ( $\left.\mathbf{k g} / \mathbf{m}^{2}\right)$ : intervention: 25.7 (1.9); control: 26.2 (2.5)

Total cholesterol (mmol/L): intervention: 4.94 (0.9); control: 4.57 (1.0)

HDL cholesterol (mmol/L): intervention: 1.35 (0.3); control: $1.28(0.3)$

LDL cholesterol (mmol/L): intervention: 3.38 (1.83); control: 2.74 (3.6)

Triglycerides (mmol/L): intervention: 0.94, (0.6); control: 1.24 (0.9)

Blood pressure (mmHg): intervention: SBP 114.6 (11.7); DBP 75.2 (8.4); control: SBP 117.5 (13.2); DBP $74.0(9.1)$ 
Hu 2013 (Continued)

Interventions

Type: foods high in fibre

Description: soy fibre (soluble and insoluble fibre) provided as biscuits. Average prescribed total dietary fibre intake was $27.5 \mathrm{~g} /$ day.

Nutrient components of biscuit provided. $250 \mathrm{ml}$ skim milk provided. Control group had control biscuits. Average prescribed total dietary fibre intake was $3.2 \mathrm{~g} /$ day. Soy fibre was substituted with flourbased ingredients. Approximately equivalent nutrient intake to intervention. Nutritional components of biscuit provided. $250 \mathrm{ml}$ skim milk provided.

Outcomes $\quad$ BP, lipid levels, adverse events

Notes

It appears that more than 39 were randomised, as describes two withdrawing, but exact number randomised not given: 39 were analysed

\section{Risk of bias}

\begin{tabular}{lll}
\hline Bias & Authors' judgement & Support for judgement \\
\hline $\begin{array}{l}\text { Random sequence genera- } \\
\text { tion (selection bias) }\end{array}$ & Unclear risk & No details reported \\
\hline $\begin{array}{l}\text { Allocation concealment } \\
\text { (selection bias) }\end{array}$ & Unclear risk & No details reported \\
\hline $\begin{array}{l}\text { Blinding of participants } \\
\text { and personnel (perfor- } \\
\text { mance bias) } \\
\text { All outcomes }\end{array}$ & Unclear risk & No details reported \\
\hline $\begin{array}{l}\text { Blinding of outcome as- } \\
\text { sessment (detection bias) }\end{array}$ & Unclear risk & No details reported \\
All outcomes & & \\
\hline $\begin{array}{l}\text { Incomplete outcome data } \\
\text { (attrition bias) }\end{array}$ & Low risk & All participants included in analysis \\
\hline $\begin{array}{l}\text { All outcomes } \\
\text { Selective reporting (re- } \\
\text { porting bias) }\end{array}$ & Unclear risk & Data not fully reported for adverse events \\
\hline \begin{tabular}{l} 
Other bias \\
\hline
\end{tabular} & Unclear risk & Not enough information to judge \\
\hline
\end{tabular}

\section{Jackson 1999}

\section{Methods}

Setting: UK, setting not reported

Design: individual randomisation, parallel group

Dates: not reported

Intervention duration: eight weeks with twelve week follow-up
Participants
N: 54 randomised (27 in each group); no drop-outs

Inclusion criteria: healthy, men and women, moderately raised fasting TC and TAG levels, aged between 35 years and 65 years, BMI $20 \mathrm{~kg} / \mathrm{m} 2$ to $32 \mathrm{~kg} / \mathrm{m} 2$, no history of heart disease, diabetes or other endocrine or liver disease. Aerobic exercise fewer than three sessions of 30 mins/week. Not taking med- 
ications for hyperlipidaemia or that could affect plasma lipid levels, not trying to lose weight, taking antibiotics or dietary fatty acid supplements.

Exclusion criteria: covered above

Age (years): mean (SD) intervention: 52.6 (8.6); control: 51.9 (10.5)

Sex (\% men): not reported

Ethnicity: not reported

Cardiovascular risk status: mean (SD)

BMI ( $\left.\mathbf{k g} / \mathbf{m}^{2}\right)$ : intervention: 26.5 (3.6); control: 26.1 (2.8)

Total cholesterol (mmol/L): intervention: 5.86 (1.00); control: 6.43 (0.79)

HDL cholesterol (mmol/L): intervention: 1.24 (0.28); control: 1.26 (0.28)

LDL cholesterol (mmol/L): intervention: 3.97 (0.86); control: 4.55 (0.92)

Triglycerides (mmol/L): intervention: 1.46 (0.55); control: $1.40(0.40)$

Blood pressure (mm Hg): not reported

Interventions Type: fibre supplements

Description: $10 \mathrm{~g}$ Inulin (soluble fibre) sachets, two mixed with water or other drinks. Provided as fourweek batches.

Control group consumed maltodextrins (placebo), provided and used in same way as intervention

\begin{tabular}{ll}
\hline Outcomes Lipid levels \\
\hline Notes
\end{tabular}

\section{Risk of bias}

\begin{tabular}{lll}
\hline Bias & Authors' judgement & Support for judgement \\
\hline $\begin{array}{l}\text { Random sequence genera- } \\
\text { tion (selection bias) }\end{array}$ & Unclear risk & No details of randomisation schedule \\
\hline $\begin{array}{l}\text { Allocation concealment } \\
\text { (selection bias) }\end{array}$ & Unclear risk & No details reported \\
\hline $\begin{array}{l}\text { Blinding of participants } \\
\text { and personnel (perfor- } \\
\text { mance bias) } \\
\text { All outcomes }\end{array}$ & Low risk & States double blind \\
\hline
\end{tabular}

\begin{tabular}{lll}
\hline $\begin{array}{l}\text { Blinding of outcome as- } \\
\text { sessment (detection bias) } \\
\text { All outcomes }\end{array}$ & Unclear risk & No details reported \\
\hline $\begin{array}{l}\text { Incomplete outcome data } \\
\text { (attrition bias) }\end{array}$ & Low risk & No loss to follow-up \\
All outcomes & \\
\hline
\end{tabular}

Selective reporting (re- $\quad$ Unclear risk $\quad$ All outcomes stated were reported but unable to fully judge
porting bias)


Jackson 1999 (Continued)

Other bias Unclear risk Not enough information to judge

Lehtimaki 2005

Methods Setting: Finland, setting not reported

Design: Individual randomisation, cross-over RCT

Dates: not reported

Intervention duration: three months (until first cross-over), seven-month study in total

Participants $\quad$ N: 96 randomised (48 to each group)

Inclusion criteria: middle aged men and women, plasma total cholesterol of $4.8-6.8 \mathrm{mmol} / \mathrm{L}$ with plasma triglyceride less than $3.0 \mathrm{mmol} / \mathrm{L}$ at end of one month run in. Aged $18-65$ years

Exclusion criteria: diabetes, renal, liver, adrenal disease, thyroid dysfunction, coronary artery or cerebrovascular disease, malignancy or terminal condition; use of lipid lowering medications, functional foods, or steroids; alcoholism or narcotic addiction; mental lability; pregnant, lactation and childbearing potential for women not using birth control, history of participation in another drug evaluation study within one month, severe adverse events caused by chitosan, allergy to crustaceans.

Age (years): reported for subgroups by genotype (apolipoprotein E e4 carriers or not) only.

Sex (\% men): reported for subgroups by genotype (apolipoprotein E e4 carriers or not) only.

Ethnicity: not reported

Cardiovascular risk status:

BMI ( $\left.\mathbf{k g} / \mathbf{m}^{2}\right)$ : reported for subgroups by genotype (apolipoprotein E e4 carriers or not) only.

Total cholesterol ( $\mathbf{m m o l} / \mathbf{L})$ : reported for subgroups by genotype (apolipoprotein E e4 carriers or not) only.

HDL cholesterol ( $\mathbf{m m o l} / \mathbf{L})$ : reported for subgroups by genotype (apolipoprotein E e4 carriers or not) only.

LDL cholesterol (mmol/L): reported for subgroups by genotype (apolipoprotein E e4 carriers or not) only.

Triglycerides ( $\mathbf{m m o l} / \mathbf{L})$ : reported for subgroups by genotype (apolipoprotein E e4 carriers or not) only.

Blood pressure ( $\mathbf{m m} \mathbf{H g})$ : reported for subgroups by genotype (apolipoprotein E e4 carriers or not) only.

Interventions Type: fibre supplements

Description: hard gelatine capsules containing $400 \mathrm{mg}$ of chitosan powder (soluble fibre). Three capsules twice a day before meals at 06:00 to 09:00 and 17:00 to 20:00. Control consumed placebo capsules with $400 \mathrm{mg}$ starch, taken with same procedure

Outcomes Lipid levels

Notes

\section{Risk of bias}


Lehtimaki 2005 (Continued)

Random sequence genera- Unclear risk No details reported
tion (selection bias)

Allocation concealment $\quad$ Unclear risk $\quad$ No details reported
(selection bias)

\begin{tabular}{|c|c|c|}
\hline $\begin{array}{l}\text { Blinding of participants } \\
\text { and personnel (perfor- }\end{array}$ & Low risk & $\begin{array}{l}\text { States double blind and placebo, pharmacist numbered treatment containers } \\
\text { to a randomisation list and codes not open until close of study }\end{array}$ \\
\hline
\end{tabular}

mance bias)

All outcomes

\begin{tabular}{lll}
\hline $\begin{array}{l}\text { Blinding of outcome as- } \\
\text { sessment (detection bias) } \\
\text { All outcomes }\end{array}$ & Unclear risk & No details reported \\
\hline $\begin{array}{l}\text { Incomplete outcome data } \\
\begin{array}{l}\text { (attrition bias) } \\
\text { All outcomes }\end{array}\end{array}$ & High risk & Numbers and details provided, difference in drop-outs between groups \\
\hline $\begin{array}{l}\text { Selective reporting (re- } \\
\text { porting bias) }\end{array}$ & High risk & No data reported \\
\hline Other bias & Unclear risk & Not enough information to judge \\
\hline
\end{tabular}

\title{
Maki 2007
}

Methods

\author{
Setting: USA, outpatient setting \\ Design: individual randomisation, parallel group \\ Dates: not reported
}

Intervention duration: 12 weeks

Participants

$\mathrm{N}$ : 97 randomised (intervention $\mathrm{N}=49$; control $\mathrm{N}=48$ ); baseline characteristics and results based on intervention $\mathrm{N}=26$; control $\mathrm{N}=34$.

Inclusion criteria: elevated systolic blood pressure $(130 \mathrm{mmHg}$ to $179 \mathrm{mmHg}$ ) or diastolic blood pressure $(85 \mathrm{mmHg}$ to $109 \mathrm{mmHg}$ ) that was untreated or suboptimally controlled with one or two antihypertensive medications, or both. Waist circumference $87 \mathrm{~cm}$ or more for women and $95 \mathrm{~cm}$ or more for men and willing to maintain current weight and activity level during study period. Age 40 years or more.

Exclusion criteria: evidence of secondary cause of hypertension, use of over-the-counter drugs containing pseudoephedrine or other vasoconstrictors, mid-upper arm circumference $42 \mathrm{~cm}$ or more, daily fibre intake $20 \mathrm{~g} /$ day or more, pregnant, lactating, planning pregnancy or of childbearing potential not using approved contraception, use of omega-3 fatty acid or herbal supplements, weight-loss drugs, systemic corticosteroids, androgens, phenytoin, erythromycin, drugs other than stable-dose aspirin for regulating haemostasis, severe asthma, conditions that require periodic use of steroids, recent history or current diagnosis of unstable angina, CHF, MI, revascularisation, hypothyroidism, significant anaemia hyperadrenocorticalism, significant gastrointestinal, renal, pulmonary, hepatic or biliary disease, diabetes, cancer within five years, recent history or strong potential for alcohol or substance abuse

Age (years): mean (SD); intervention: 63.0 (9.2); control: 57.1 (9.3)

Sex (\% men): intervention: $53.8 \%$; control: $55.9 \%$ 
Maki 2007 (Continued)

Ethnicity: intervention: white $69.2 \%$, black $26.9 \%$, other $3.8 \%$; control: White $55.9 \%$, Black 44.1, Other 0.0

Cardiovascular risk status: mean (SD)

BMI ( $\left.\mathbf{k g} / \mathbf{m}^{2}\right)$ : intervention: 32.6 (5.1); control: 32.2 (5.3)

Total cholesterol (mmol/L): not reported

HDL cholesterol (mmol/L): not reported

LDL cholesterol ( $\mathbf{m m o l} / \mathrm{L})$ : not reported

Triglycerides ( $\mathrm{mmol} / \mathrm{L})$ : not reported

Blood pressure (mmHg): intervention: SBP 138.9, (9.7); DBP 82.8, (7.7); control: SBP 139.9 (9.3); DBP $83.9,(5.8)$

Interventions

Type: provision of foods high in fibre

Description: Oat beta-glucans (intervention) group received a ready to eat cold cereal made with oat bran, oatmeal, and a powered form of oat B-glucans (soluble fibre).

Control: a low-fibre, ready-to-eat, cold, wheat-based cereal, a low-fibre hot cereal and a control maltodextrin powder.

Both groups: participants instructed to eat three servings (one of each) per day Nutritional composition reported

Outcomes BP (no data reported)

Notes

\section{Risk of bias}

\begin{tabular}{lll}
\hline Bias & Authors' judgement & Support for judgement \\
\hline $\begin{array}{l}\text { Random sequence genera- } \\
\text { tion (selection bias) }\end{array}$ & Unclear risk & No details reported \\
\hline
\end{tabular}

\begin{tabular}{lll}
\hline $\begin{array}{l}\text { Allocation concealment } \\
\text { (selection bias) }\end{array}$ & Unclear risk & No details reported
\end{tabular}

Blinding of participants Low risk $\quad$ States double blind
and personnel (perfor-
mance bias)

\begin{tabular}{lll}
\hline Blinding of outcome as- & Unclear risk $\quad$ No details reported
\end{tabular}
sessment (detection bias) All outcomes

Incomplete outcome data High risk $\quad$ High loss to follow-up
(attrition bias)

\begin{tabular}{lll}
\hline $\begin{array}{l}\text { Selective reporting (re- } \\
\text { porting bias) }\end{array}$ & High risk & No data reported \\
\hline Other bias & Unclear risk & Not enough information to judge \\
\hline
\end{tabular}




\section{Methods}

Methods
Setting: Finland, setting not reported

Design: individual randomisation, parallel group

Dates: not reported

Intervention duration: six months
$\mathbf{N}: 30$ randomised (15 in each group). Baseline characteristics and results reported on different N's (where differ reported below)

Inclusion criteria: women with climacteric symptoms, all normotensive. Hormonal therapy if used had been stopped for three months

Exclusion criteria: no diabetes, liver disease or thromboembolic disease.

Age (years): mean (SD); intervention: 52.3 (2.7); control: 53.6 (4.0)

Sex (\% men): $0 \%$

Ethnicity: not reported

Cardiovascular risk status: mean (SD)

$B M I\left(k g / m^{2}\right)$ : not reported

Total cholesterol (mmol/L): intervention: 7.51 (1.47), N = 15; control: 6.98 (0.63), N = 14

HDL cholesterol (mmol/L): intervention: 1.25 (0.39), N = 15; control: 1.31 (0.25), N = 12

LDL cholesterol (mmol/L): not reported

Triglycerides (mmol/L): intervention: 1.74 (0.63), N = 15; control: $1.73(0.83), \mathrm{N}=14$

Blood pressure (mmHg): intervention: SBP 144.33 (21.66); DBP $92.6(9.86) \mathrm{N}=15$; control: SBP 148.8 (12.90); DBP 92.8 (7.89), $\mathrm{N}=15$
Type: fibre supplements

Description: granulated guar gum (soluble fibre), $5 \mathrm{~g}$ three times per day. Control: placebo (wheat flour granules) $5 \mathrm{~g}$ three times per day

Outcomes BP, lipid levels, adverse events

Notes

\section{Risk of bias}

\begin{tabular}{lll}
\hline Bias & Authors' judgement & Support for judgement \\
\hline $\begin{array}{l}\text { Random sequence genera- } \\
\text { tion (selection bias) }\end{array}$ & Unclear risk & No details reported \\
\hline $\begin{array}{l}\text { Allocation concealment } \\
\text { (selection bias) }\end{array}$ & Unclear risk & No details reported \\
\hline $\begin{array}{l}\text { Blinding of participants } \\
\text { and personnel (perfor- } \\
\text { mance bias) } \\
\text { All outcomes }\end{array}$ & Low risk & States double blind and placebo \\
\hline \hline
\end{tabular}


Makkonen 1993 (Continued)
Blinding of outcome as-
Unclear risk
No details reported sessment (detection bias)

All outcomes

\begin{tabular}{ll}
\hline Incomplete outcome data $\quad$ Unclear risk $\quad$ No details on loss to follow-up or ITT \\
(attrition bias)
\end{tabular}

All outcomes

Selective reporting (re- Unclear risk $\quad$ All outcomes stated were reported but unable to fully judge
porting bias)

\begin{tabular}{ll}
\hline Other bias $\quad$ Unclear risk $\quad$ Not enough information to judge \\
\hline
\end{tabular}

Marett 2004 Larch

Setting: USA, setting not reported
Design: individual randomisation, parallel groups
Dates: not reported
Intervention duration: six months

Participants $\quad$ N: 54 randomised to three groups (intervention $1 \mathrm{~N}=18$; intervention $2, \mathrm{~N}=19, \mathrm{control}, \mathrm{N}=17$ )

Inclusion criteria: healthy men and women, 18 years to 55 years

Exclusion criteria: not stated

Age (years): not reported

Sex (\% men): not reported

Ethnicity: not reported

Cardiovascular risk status: mean (SD)

$B M I\left(\mathrm{~kg} / \mathrm{m}^{2}\right)$ : not reported

Total cholesterol (mmol/L): intervention 1: 4.64 (1.00); intervention 2: 4.68 (0.99); control: 4.64 (1.04)

HDL cholesterol (mmol/L): intervention 1: 1.25 (0.27); intervention 2: 1.32 (0.22); control: 1.34 (0.26)

LDL cholesterol (mmol/L): intervention 1: 2.85 (1.00); intervention 2: 2.84 (0.96); control: 2.73 (0.83)

Triglycerides (mmol/L): intervention 1: 1.17 (0.46); intervention 2: 1.02 (0.46); control: 1.21 (0.89)

Blood pressure ( $\mathbf{m m H g})$ : not reported

$\begin{array}{ll}\text { Interventions } & \text { Type: fibre supplements } \\ & \text { Description: intervention 1: } 8.4 \mathrm{~g} \text { of larch arabinogalactan (soluble fibre); intervention 2: } 8.4 \mathrm{~g} \text { tama- } \\ \text { rack arabinogalactan (soluble fibre). control: } 8.4 \mathrm{~g} \text { placebo rice starch. Instructed to consume in a bev- } \\ \text { erage or food }\end{array}$

Outcomes

BP, lipid levels

\section{Notes}


Marett 2004 Larch (Continued)

Risk of bias

\begin{tabular}{|c|c|c|}
\hline Bias & Authors' judgement & Support for judgement \\
\hline $\begin{array}{l}\text { Random sequence genera- } \\
\text { tion (selection bias) }\end{array}$ & Unclear risk & No details reported \\
\hline $\begin{array}{l}\text { Allocation concealment } \\
\text { (selection bias) }\end{array}$ & Unclear risk & No details reported \\
\hline $\begin{array}{l}\text { Blinding of participants } \\
\text { and personnel (perfor- } \\
\text { mance bias) } \\
\text { All outcomes }\end{array}$ & Low risk & States double blind \\
\hline $\begin{array}{l}\text { Blinding of outcome as- } \\
\text { sessment (detection bias) } \\
\text { All outcomes }\end{array}$ & Unclear risk & No details reported \\
\hline $\begin{array}{l}\text { Incomplete outcome data } \\
\text { (attrition bias) } \\
\text { All outcomes }\end{array}$ & Unclear risk & No details reported \\
\hline $\begin{array}{l}\text { Selective reporting (re- } \\
\text { porting bias) }\end{array}$ & High risk & Blood pressure is an outcome but no data \\
\hline Other bias & Unclear risk & Not enough information to judge \\
\hline
\end{tabular}

Marett 2004 Tamarak

\begin{tabular}{|c|c|c|}
\hline Methods & \multicolumn{2}{|c|}{ see previous - study had three relevant study groups } \\
\hline \multicolumn{3}{|l|}{ Participants } \\
\hline \multicolumn{3}{|l|}{ Interventions } \\
\hline \multicolumn{3}{|l|}{ Outcomes } \\
\hline \multicolumn{3}{|l|}{ Notes } \\
\hline \multicolumn{3}{|l|}{ Risk of bias } \\
\hline Bias & Authors' judgement & Support for judgement \\
\hline $\begin{array}{l}\text { Random sequence genera- } \\
\text { tion (selection bias) }\end{array}$ & Unclear risk & see previous \\
\hline $\begin{array}{l}\text { Allocation concealment } \\
\text { (selection bias) }\end{array}$ & Unclear risk & see previous \\
\hline $\begin{array}{l}\text { Blinding of participants } \\
\text { and personnel (perfor- } \\
\text { mance bias) } \\
\text { All outcomes }\end{array}$ & Low risk & see previous \\
\hline
\end{tabular}


Marett 2004 Tamarak (Continued)
Blinding of outcome as-
Unclear risk
see previous sessment (detection bias)

All outcomes

Incomplete outcome data Unclear risk see previous
(attrition bias)
All outcomes

\begin{tabular}{lll}
\hline $\begin{array}{l}\text { Selective reporting (re- } \\
\text { porting bias) }\end{array}$ & High risk & see previous \\
\hline Other bias & Unclear risk & see previous \\
\hline
\end{tabular}

Nichenametla 2014

Setting: USA, community
Design: cluster randomisation with a cross over
Dates: not reported

Intervention duration: 12 weeks

Participants N: 86 randomised (study results reported for total population only, numbers differ for baseline characteristics as reported below)

Inclusion criteria: healthy participants and those with metabolic syndrome, $40.7 \%$ were taking medication for cholesterol, diabetes or blood pressure

Exclusion criteria: pregnancy, lactation, long-term antibiotic therapy, immune compromised, cancer, other long term conditions that would affect the ability to provide informed consent or comply with protocol.

Age (years): mean (SD); all: 51.7 (14.8)

Sex (\% men): all: $31.4 \%$

Ethnicity: all: described as Caucasian 100\%

Cardiovascular risk status: mean (SD)

BMI ( $\left.\mathbf{k g} / \mathbf{m}^{2}\right)$ : all: 30.9 (5.1), N = 73

Total cholesterol (mmol/L): all: 5.2 (1.39), N = 83

HDL cholesterol (mmol/L): all: $1.4(0.4), \mathrm{N}=83$

LDL cholesterol (mmol/L): all: 3.4 (1.7), N = 75

Triglycerides (mmol/L): all: 1.2 (3.1), N = 83

Blood pressure (mmHg): all: SBP 131.6 (16.5), CBP 74.4 (10.1)

Type: provision of foods high in fibre

Description: resistant starch-4 (RS4) an insoluble fibre, was substituted into the control flour. The intervention RS4-flour had a 30\% v/v substitution of RS4 (Fibersym, MGP Ingredients, Atchison, KS) in the control flour. Participants consumed RS4-flour and control flour (without RS4 substitution) ad libitum in a free-living, domestic environment in form of any flour-based recipes that would normally be prepared, to match realistic conditions. Bread, noodles, maultaschen and dumplings are the most 
Nichenametla 2014 (Continued)

frequent flour based foods in Hutterite communities. Typical Hutterite diets contain high amounts of protein, fat, cholesterol and salt, but low fibre compared with RDA levels. A large number of food options are offered at each meal in a common dining hall. Nutrient composition (g/100 g) reported. Control flour. Details as above.

Outcomes BP, lipid levels, adverse events

Notes

\section{Risk of bias}

Bias Authors' judgement Support for judgement

Random sequence genera- Unclear risk $\quad$ Two communities randomised as clusters
tion (selection bias)

tion (selection bias)

Allocation concealment $\quad$ Unclear risk $\quad$ No details reported
(selection bias)

\begin{tabular}{|c|c|c|}
\hline $\begin{array}{l}\text { Blinding of participants } \\
\text { and personnel (perfor- } \\
\text { mance bias) } \\
\text { All outcomes }\end{array}$ & Low risk & States double blind and treatments being blindly exchanged \\
\hline $\begin{array}{l}\text { Blinding of outcome as- } \\
\text { sessment (detection bias) } \\
\text { All outcomes }\end{array}$ & Unclear risk & No details reported \\
\hline $\begin{array}{l}\text { Incomplete outcome data } \\
\text { (attrition bias) } \\
\text { All outcomes }\end{array}$ & Unclear risk & Unclear which groups drop outs relate to \\
\hline $\begin{array}{l}\text { Selective reporting (re- } \\
\text { porting bias) }\end{array}$ & Unclear risk & All outcomes stated were reported but unable to fully judge \\
\hline Other bias & High risk & $\begin{array}{l}\text { Only two clusters randomised and evidence of a carry-over effect, although we } \\
\text { only intended to use data from the first half of the trial before crossover }\end{array}$ \\
\hline
\end{tabular}

\section{Pal 2011}

\begin{tabular}{|c|c|}
\hline Methods & $\begin{array}{l}\text { Setting: Australia, community setting } \\
\text { Design: individual randomisation, parallel groups } \\
\text { Dates: not reported } \\
\text { Intervention duration: } 12 \text { weeks }\end{array}$ \\
\hline Participants & $\begin{array}{l}\mathrm{N} \text { : } 72 \text { eligible participants ( } 18 \text { in each group). Baseline characteristics and results based on numbers af- } \\
\text { ter drop outs: fibre supplement: } \mathrm{N}=16 ; \text { control } \mathrm{N}=15 \\
\text { Inclusion criteria: overweight and obese, aged } 18 \text { years to } 65 \text { years } \\
\text { Exclusion criteria: smoking, lipid lowering medication, steroids, agents that may influence lipid me- } \\
\text { tabolism, warfarin, diabetes, hypo or hyperthyroidism, cardiovascular events in last six months, psy- } \\
\text { chological unsuitability, major systemic disease, gastrointestinal problems, proteinuria, liver failure, } \\
\text { renal failure, weight fluctuations six months, vegetarian }\end{array}$ \\
\hline
\end{tabular}


Pal 2011 (Continued)

Age (years): mean (SD); fibre supplement: 41.3 (9.2); control: 44.8 (6.2)

Sex (\% men): not reported

Ethnicity: not reported

Cardiovascular risk status: mean (SD)

BMI ( $\left.\mathbf{k g} / \mathbf{m}^{2}\right)$ : fibre supplement: 34.0 (3.6); control: 33.7 (3.9)

Total cholesterol (mmol/L): fibre supplement: 5.9 (4.8): control: 6.1 (4.6)

HDL cholesterol (mmol/L): fibre supplement: 1.3 (0.4); control: $1.3(0.4)$

LDL cholesterol (mmol/L): fibre supplement: 4.0 (1.2); control: 3.9 (1.2)

Triglycerides (mmol/L): fibre supplement: 1.5 (0.8); control: 2.0 (1.2)

Blood pressure (mmHg): fibre supplement: SBP 115.0 (10.0); DBP 66.4 (10.4); control: SBP 114.3 (10.5); DBP $66.3(8.9)$

\section{Interventions Type: fibre supplement with usual diet}

Description: four groups: intervention 1: fibre supplement with usual diet, $12 \mathrm{~g}$ psyllium (soluble fibre); control: placebo with usual diet; Intervention 2: fibre supplement with healthy eating advice, $12 \mathrm{~g}$ psyillium (not reported here); intervention 3: healthy eating advice with placebo (not reported here). Psyllium was mixed with $250 \mathrm{ml}$ water and taken three times per day. The placebo consisted of breadcrumbs with flavouring to give $1.5 \mathrm{~g}$ soluble fibre.

Outcomes BP, lipid levels

\section{Notes}

\section{Risk of bias}

\begin{tabular}{lll}
\hline Bias & Authors' judgement & Support for judgement \\
\hline $\begin{array}{l}\text { Random sequence genera- } \\
\text { tion (selection bias) }\end{array}$ & Unclear risk & No details reported \\
\hline $\begin{array}{l}\text { Allocation concealment } \\
\text { (selection bias) }\end{array}$ & Unclear risk & No details reported \\
\hline $\begin{array}{l}\text { Blinding of participants } \\
\text { and personnel (perfor- } \\
\text { mance bias) }\end{array}$ & High risk & Single blinded study \\
All outcomes & & \\
\hline
\end{tabular}

$\begin{array}{ll}\text { Blinding of outcome as- } & \text { Unclear risk }\end{array}$

$$
\text { All outcomes }
$$

Incomplete outcome data High risk High loss to follow up, no ITT, differences between groups
(attrition bias)

All outcomes

Selective reporting (re- Unclear risk $\quad$ All outcomes stated were reported but unable to fully judge
porting bias)

\begin{tabular}{|c|c|c|}
\hline Other bias & Unclear risk & Not enough information to judge \\
\hline
\end{tabular}


Design: individual randomisation, parallel group

Dates: not reported

Intervention duration: 16 weeks

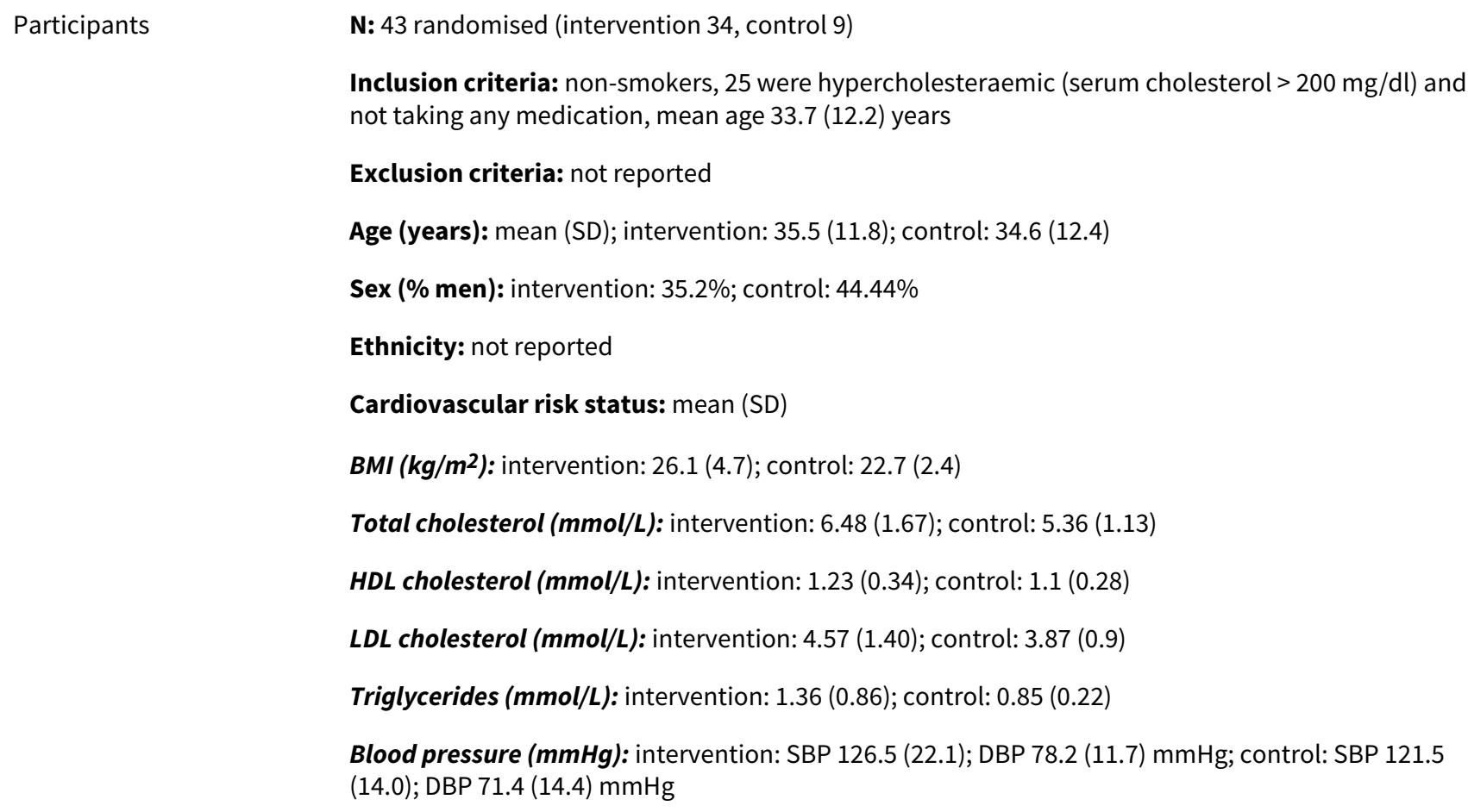

Inclusion criteria: non-smokers, 25 were hypercholesteraemic (serum cholesterol $>200 \mathrm{mg} / \mathrm{dl}$ ) and not taking any medication, mean age 33.7 (12.2) years

Exclusion criteria: not reported

Age (years): mean (SD); intervention: 35.5 (11.8); control: 34.6 (12.4)

Sex (\% men): intervention: $35.2 \%$; control: $44.44 \%$

Ethnicity: not reported

Cardiovascular risk status: mean (SD)

BMI ( $\left.\mathbf{k g} / \mathbf{m}^{2}\right)$ : intervention: 26.1 (4.7); control: 22.7 (2.4)

Total cholesterol (mmol/L): intervention: 6.48 (1.67); control: 5.36 (1.13)

HDL cholesterol (mmol/L): intervention: 1.23 (0.34); control: 1.1 (0.28)

LDL cholesterol (mmol/L): intervention: 4.57 (1.40); control: 3.87 (0.9)

Triglycerides (mmol/L): intervention: 1.36 (0.86); control: 0.85 (0.22)

Blood pressure ( $\mathbf{m m H g}$ ): intervention: SBP 126.5 (22.1); DBP 78.2 (11.7) mmHg; control: SBP 121.5 (14.0); DBP 71.4 (14.4) $\mathrm{mmHg}$

\begin{tabular}{lll}
\hline Interventions & Type: fibre supplements & $\begin{array}{l}\text { Description: grape antioxidant dietary fibre (GA } \\
\text { consumed for 16 weeks at 7.5 g daily in individ } \\
\text { Control: consumed regular diet }\end{array}$ \\
\hline Outcomes & BP, lipid levels, adverse events \\
\hline Notes & & \\
\hline Risk of bias & Authors' judgement & Support for judgem \\
\hline Bias & Unclear risk & No details reported \\
\hline $\begin{array}{l}\text { Random sequence genera- } \\
\text { tion (selection bias) }\end{array}$ & & No details reported \\
\hline $\begin{array}{l}\text { Allocation concealment } \\
\text { (selection bias) }\end{array}$ & Unclear risk & No details reported \\
\hline $\begin{array}{l}\text { Blinding of participants } \\
\text { and personnel (perfor- } \\
\text { mance bias) }\end{array}$ & Unclear risk & \\
\hline
\end{tabular}


Perez-Jiminez 2008 (Continued)

All outcomes

$\begin{array}{lll}\text { Blinding of outcome as- } & \text { Unclear risk } & \text { No details reported } \\ \text { sessment (detection bias) } & \end{array}$

sessment (detection bias)

All outcomes

Incomplete outcome data High risk Numbers reported without reasons, difference between groups
(attrition bias)

All outcomes

\begin{tabular}{lll}
\hline $\begin{array}{l}\text { Selective reporting (re- } \\
\text { porting bias) }\end{array}$ & Unclear risk & No details reported \\
\hline Other bias & Unclear risk & Not enough details to judge \\
\hline
\end{tabular}

Pins 2002

Methods

Setting: USA, setting not reported

Design: parallel randomised controlled trial

Dates: not reported

Intervention duration: 12 weeks

Inclusion criteria: mild or moderate hypertension treated with no more than one antihypertensive (excluding beta-blockers)

Exclusion criteria: history of systolic BP > $160 \mathrm{mmHg}$ or diastolic BP > $115 \mathrm{mmHg}$; existing complications of hypertension; history of major intestinal surgeries; malabsorption of the gastrointestinal tract or biliary disease; use of beta-blockers; diabetes mellitus; body mass index $>35$; history of excessive use of alcohol; current smoking; high soluble fibre intake; clinical use of antacids, bulk laxatives or other medications affecting gastrointestinal tract; continuous treatment with oestrogen replacements, participation in another study three months before randomisation

Age (years): control group 46.4 years (+/- 15.3 SD); intervention group 48.7 years (+/- 16.9 SD)

Sex (\% men): male/female ratio: $45 / 43$

Ethnicity: 96\%/98\% (intervention/control) Caucasian

Baseline cardiovascular risk status:

BMI ( $\left.\mathbf{k g} / \mathbf{m}^{2}\right)$ : intervention: 31.2 (5.1); control: 30.6 (4.7)

Total cholesterol (mmol/L): intervention: 5.47 (0.99); control: 5.53 (1.09)

HDL cholesterol (mmol/L): intervention: 1.11 (0.24); control: $1.14(0.26)$

LDL cholesterol (mmol/L): intervention: 3.59 (0.76); control: 3.56 (0.71)

Triglycerides (mmol/L): intervention: 2.09 (0.45); control: 2.16 (0.47)

Blood pressure (mmHg): intervention: SBP 140 (16); DBP 88 (10) mmHg; control: SBP 138 (15); DBP 86 (9) $\mathrm{mmHg}$

Medications used: no more than one anti-hypertensive medication and/or one diuretic medication. Eighty participants were on a single anti-hypertensive medication, eight were on an anti-hypertensive drug plus a diuretic medication. 
Pins 2002 (Continued)

Interventions

Type: provision of foods high in fibre

Description: whole oat cereals (Quaker Oatmeal and Oat Squares) eaten as part of usual diet.

The control group received refined grain wheat-based cereals (hot wheat cereal and Kellogg's Crispix) eaten as part of usual diet. The intervention group received the following: $60 \mathrm{~g}$ Quaker oatmeal (5.61 $\mathrm{g}$ total dietary fibre, $3.25 \mathrm{~g}$ soluble fibre and $2.83 \mathrm{~g}$ beta-glucans) and $77 \mathrm{~g}$ Quaker Oatmeal Squares (6.07 $\mathrm{g}$ total fibre, $2.98 \mathrm{~g}$ soluble fibre, $2,59 \mathrm{~g}$ beta-glucans). The control group received the following: $65 \mathrm{~g}$ Malt-O-Meal hot wheat cereal (2.32 g total dietary fibre, $0.6 \mathrm{~g}$ soluble fibre) and $81 \mathrm{~g}$ Kelloggs Crispix (1.2 $\mathrm{g}$ dietary fibre, $<0.5 \mathrm{~g}$ soluble fibre). Cereal treatments were isocaloric

Outcomes Total cholesterol, HDL cholesterol, LDL cholesterol, triglycerides. Proportion of participants reducing anti-hypertensive medication (no variance provided), mean BP (no variance provided). Adverse events

Notes

Test cereals and funding were provided by the Quaker Oats Company

All participants were on anti-hypertensive treatment at the start of the study. This was reduced by half at four weeks and fully at 12 weeks if participants' blood pressure was within certain limits. We have not used the blood pressure data from this trial because of the varying effects of antihypertensive medication throughout the trial confounding any effects of fibre

\section{Risk of bias}

\begin{tabular}{|c|c|c|}
\hline Bias & Authors' judgement & Support for judgement \\
\hline $\begin{array}{l}\text { Random sequence genera- } \\
\text { tion (selection bias) }\end{array}$ & Unclear risk & Not reported \\
\hline $\begin{array}{l}\text { Allocation concealment } \\
\text { (selection bias) }\end{array}$ & Unclear risk & Not reported \\
\hline $\begin{array}{l}\text { Blinding of participants } \\
\text { and personnel (perfor- } \\
\text { mance bias) } \\
\text { All outcomes }\end{array}$ & Low risk & Cereals were dispensed in unlabelled bulk containers to facilitate blinding \\
\hline $\begin{array}{l}\text { Blinding of outcome as- } \\
\text { sessment (detection bias) } \\
\text { All outcomes }\end{array}$ & Low risk & The outcome assessor was blinded to group allocation \\
\hline $\begin{array}{l}\text { Incomplete outcome data } \\
\text { (attrition bias) } \\
\text { All outcomes }\end{array}$ & Low risk & All 88 subjects randomised appear to have completed the study \\
\hline $\begin{array}{l}\text { Selective reporting (re- } \\
\text { porting bias) }\end{array}$ & Unclear risk & All outcomes stated were reported but unable to fully judge \\
\hline Other bias & High risk & $\begin{array}{l}\text { Study was funded by the Quaker Oats Company who also provided cereals for } \\
\text { the intervention. }\end{array}$ \\
\hline
\end{tabular}

Reimer 2013

$\begin{array}{ll}\text { Methods } & \text { Setting: Japan, setting not reported } \\ \text { Design: individual randomisation, parallel group } \\ \text { Dates: not reported }\end{array}$


Reimer 2013 (Continued)

Intervention duration: 14 weeks

Participants

$\mathbf{N}: 64$ randomised ( $N=32$ to each group). Baseline characteristics and results based on $\mathrm{N}=28$ for both groups

Inclusion criteria: BMI $24-30 \mathrm{~kg} / \mathrm{m} 2$ and waist circumference $>85 \mathrm{~cm}$ (males) or $>90 \mathrm{~cm}$ (females), aged 20 years to 65 years.

Exclusion criteria: heavier than $100 \mathrm{~kg}$, attempting to lose weight, taking medications that alter blood lipids or blood glucose, under medically supervised treatments for hyperlipidaemia, diabetes or obesity, history of allergy to test products, disease that requires medication, participation in another trial, pregnancy, breast feeding

Age (years): not reported

Sex (\% men): $43.7 \%$ for both groups (randomised $N=64$ )

Ethnicity: not reported

Cardiovascular risk status: mean (SD)

BMI ( $\left.\mathbf{k g} / \mathbf{m}^{2}\right)$ : intervention: 26.7 (1.1); control: 27.2 (1.6)

Total cholesterol (mmol/L): intervention: 5.63 (1.1); control: 5.32 (0.8)

HDL cholesterol (mmol/L): intervention: 1.45 (0.3); control: 1.39 (0.3)

LDL cholesterol (mmol/L): intervention: 3.69 (0.8); control: 3.41 (0.7)

Triglycerides (mmol/L): intervention: 1.38 (0.8); control: 1.29 (0.7)

Blood pressure (mm Hg): intervention: SBP 123.6 (11.1); DBP 75.1 (6.9); control: SBP 120.2 (14.3); DBP $75.1(13.2)$

Type: fibre supplements

Description: PolyGlycoplex (PGX) (soluble fibre). Provided in packets labelled A or B, five minutes before each meal, $5 \mathrm{~g}$ of PGX was mixed with yogurt. Days one to three, $5 \mathrm{~g}$ per day, days four to seven, 10 $\mathrm{g}$ per day, days eight to $97,15 \mathrm{~g}$ per day. Control: same as intervention but with rice flour placebo

Outcomes BP, lipid levels, adverse events

Notes

Risk of bias

\begin{tabular}{lll}
\hline Bias & Authors' judgement & Support for judgement \\
\hline $\begin{array}{l}\text { Random sequence genera- } \\
\text { tion (selection bias) }\end{array}$ & Unclear risk & No details reported \\
\hline $\begin{array}{l}\text { Allocation concealment } \\
\text { (selection bias) }\end{array}$ & Unclear risk & No details reported \\
\hline $\begin{array}{l}\text { Blinding of participants } \\
\text { and personnel (perfor- } \\
\text { mance bias) }\end{array}$ & Low risk & Used placebo, states study coordinator and participants blinded to product \\
All outcomes & \\
\hline
\end{tabular}

Blinding of outcome as-
sessment (detection bias) $\quad$ Unclear risk No details reported


Reimer 2013 (Continued)

All outcomes

Incomplete outcome data Unclear risk Loss to follow-up reported with reasons
(attrition bias)

All outcomes

\begin{tabular}{lll}
\hline $\begin{array}{l}\text { Selective reporting (re- } \\
\text { porting bias) }\end{array}$ & Unclear risk & All outcomes stated were reported but unable to fully judge \\
\hline Other bias & Unclear risk & Not enough information to judge \\
\hline
\end{tabular}

Schlamovitz 1987

\begin{tabular}{ll}
\hline Methods & Setting: Denmark, setting not reported \\
Design: individual randomisation, parallel group \\
Dates: not reported \\
Intervention duration: 12 weeks \\
\hline
\end{tabular}

Participants

N: 46 randomised (Intervention 21, Control 25)

Inclusion criteria: mild to moderate hypertension (BP between 140/95 and 198/110). Described as 'lean' patients. No further details

Exclusion criteria: not reported

Age (years): not reported

Sex (\% men): not reported

Ethnicity: not reported

Cardiovascular risk status: mean (SD)

$B M I\left(k g / m^{2}\right):$ not reported

Total cholesterol (mmol/L): not reported

HDL cholesterol (mmol/L): intervention: 5.9 (1.3); control: 6.5 (1.2)

LDL cholesterol ( $\mathbf{m m o l} / \mathrm{L})$ : not reported

Triglycerides ( $\mathbf{m m o l} / \mathbf{L}$ ): not reported

Blood pressure (mmHg): intervention: SBP 157 (17.6), DBP 97 (6.6); control: SBP 150 (12.1), DBP 96 (7.3)

Interventions

Type: fibre supplements

Description: FibreTrim Plus tablets, Farma Food (soluble fibre). Tablets contain about $58 \%$ fibre from grain, citrus fruit, and vegetables. Total dietary fibre supplement $7 \mathrm{~g}$ per day. Control given placebo (no further details)

Outcomes BP, lipid levels, adverse events

\section{Notes}

\section{Risk of bias}

Dietary fibre for the primary prevention of cardiovascular disease (Review) 
Schlamovitz 1987 (Continued)

\begin{tabular}{lll} 
Bias & Authors' judgement & Support for judgement \\
\hline $\begin{array}{l}\text { Random sequence genera- } \\
\text { tion (selection bias) }\end{array}$ & Unclear risk & No details reported \\
\hline
\end{tabular}

\begin{tabular}{|c|c|c|}
\hline $\begin{array}{l}\text { Allocation concealment } \\
\text { (selection bias) }\end{array}$ & Unclear risk & No details reported \\
\hline $\begin{array}{l}\text { Blinding of participants } \\
\text { and personnel (perfor- } \\
\text { mance bias) } \\
\text { All outcomes }\end{array}$ & Low risk & States double blind, objective outcome measures \\
\hline $\begin{array}{l}\text { Blinding of outcome as- } \\
\text { sessment (detection bias) } \\
\text { All outcomes }\end{array}$ & Unclear risk & No details reported \\
\hline $\begin{array}{l}\text { Incomplete outcome data } \\
\text { (attrition bias) } \\
\text { All outcomes }\end{array}$ & Unclear risk & No details reported \\
\hline $\begin{array}{l}\text { Selective reporting (re- } \\
\text { porting bias) }\end{array}$ & High risk & Letter with limited information, however, triglycerides data missing \\
\hline Other bias & Unclear risk & Not enough information to judge \\
\hline
\end{tabular}

Shimizu 2008

\begin{tabular}{|c|c|}
\hline Methods & $\begin{array}{l}\text { Setting: Japan, setting not stated } \\
\text { Design: individual randomisation, parallel group } \\
\text { Dates: not reported } \\
\text { Intervention duration: } 12 \text { weeks }\end{array}$ \\
\hline Participants & $\begin{array}{l}\text { N: } 44 \text { randomised ( } 22 \text { to each group). Baseline characteristics and results based on numbers after drop } \\
\text { out (intervention } \mathrm{N}=19 \text {, control } \mathrm{N}=20 \text { ) } \\
\text { Inclusion criteria: } \mathrm{BMI}>22 \mathrm{Kg} / \mathrm{m}^{2} \text {, LDL-C } 140-220 \mathrm{mg} / \mathrm{dl} \text {. Total C } 220-300 \mathrm{mg} / \mathrm{dl} \text {. Habitually consumed } \\
\text { pearled rice as a staple food more than twice in three daily meals, age } 30 \text { years to } 60 \text { years } \\
\text { Exclusion criteria: Heart, liver, kidney disease, food allergies, exercise habits daily, body weight in- } \\
\text { crease or decrease by > } 10 \mathrm{~kg} \text { in past three months, irregular lifestyle habits, medication or functional } \\
\text { foods known to affect lipid metabolism } \\
\text { Age (years): mean (SD); intervention: } 42.1 \text { (9.2) control: } 40.9 \text { (7.8) } \\
\text { Sex (\% men): not reported } \\
\text { Ethnicity: not reported } \\
\text { Cardiovascular risk status: mean (SD) } \\
\text { BMI (kg/m2): intervention: } 26.2 \text { (2.8); control: } 24.5 \text { (2.4) } \\
\text { Total cholesterol (mmol/L): intervention: } 6.07 \text { (0.56); control: } 6.36 \text { (0.70) } \\
\text { HDL cholesterol (mmol/L): not reported }\end{array}$ \\
\hline
\end{tabular}


Shimizu 2008 (Continued)

LDL cholesterol (mmol/L): intervention: 3.97 (0.42); control: 4.14 (0.62)

Triglycerides ( $\mathbf{m m o l} / \mathbf{L}$ ) not reported

Blood pressure $(\mathrm{mmHg})$ : not reported

Interventions Type: provision of foods high in fibre

Description: High beta-glucagon barley (insoluble fibre), each package contained 50\% barley and 50\% rice in a package $(160 \mathrm{~g})$ and participants consumed 2 packages daily in replacement of the pearled rice in their staple food. The dietary fibre content of each package was $4.5 \mathrm{~g}$ of which beta-glucagon was 3.5 $\mathrm{g}$ per package (so $7 \mathrm{~g}$ per day in total). The control group consumed rice only in a package $(139 \mathrm{~g})$ and consumed two packages daily.

Outcomes Lipid levels

Notes

\section{Risk of bias}

\begin{tabular}{|c|c|c|}
\hline Bias & Authors' judgement & Support for judgement \\
\hline $\begin{array}{l}\text { Random sequence genera- } \\
\text { tion (selection bias) }\end{array}$ & Unclear risk & States randomised on basis of baseline factors but no other details \\
\hline $\begin{array}{l}\text { Allocation concealment } \\
\text { (selection bias) }\end{array}$ & Unclear risk & No details reported \\
\hline $\begin{array}{l}\text { Blinding of participants } \\
\text { and personnel (perfor- } \\
\text { mance bias) } \\
\text { All outcomes }\end{array}$ & Low risk & States double blind, same packaging used \\
\hline $\begin{array}{l}\text { Blinding of outcome as- } \\
\text { sessment (detection bias) } \\
\text { All outcomes }\end{array}$ & Unclear risk & No details reported \\
\hline $\begin{array}{l}\text { Incomplete outcome data } \\
\text { (attrition bias) } \\
\text { All outcomes }\end{array}$ & High risk & Dropouts not described per study group \\
\hline $\begin{array}{l}\text { Selective reporting (re- } \\
\text { porting bias) }\end{array}$ & Unclear risk & All outcomes stated were reported but unable to fully judge \\
\hline Other bias & Unclear risk & Not enough information to judge \\
\hline
\end{tabular}

Tighe 2010 Wheat

$\begin{array}{ll}\text { Methods } & \text { Setting: UK, setting not described } \\ & \text { Design: individual randomisation, parallel group } \\ & \text { Dates: June } 2005 \text { to September } 2008 \\ \text { Intervention duration: } 12 \text { weeks } & \text { N: } 226 \text { randomised (intervention } 1: \mathrm{N}=77 ; \text { intervention } 2: \mathrm{N}=73 ; \text { control: } \mathrm{N}=76 \text { ). Baseline characteris- } \\ \text { tics and results based on Intervention } 1: \mathrm{N}=73: \text { intervention } 2: \mathrm{N}=70 ; \text { control: } \mathrm{N}=63\end{array}$


Tighe 2010 Wheat (Continued)

Inclusion criteria: BMI $18.5-35 \mathrm{~kg} / \mathrm{m}^{2}$, sedentary or moderately active (fewer than two aerobic sessions per week), aged 40-60 years, signs of metabolic syndrome or moderate hypercholesterolaemia.

Exclusion criteria: CVD, diabetes, fasting blood glucose $>7 \mathrm{mmol} / \mathrm{L}$, asthma, $\mathrm{SBP}>160 \mathrm{mmHg}$ or DBP

$>99 \mathrm{mmHg}$, thyroid or eating disorders, high habitual intake of whole grain foods, regular mediation or supplements known to affect any outcomes.

Age (years): mean (SD); intervention 1:51.6 (7.4); intervention 2:52.1 (7.4); control: 51.8 (7.4)

Sex (\% men): intervention 1: 53\%; intervention 2: 51\%; control: $47 \%$

Ethnicity: not reported

Cardiovascular risk status: mean (SD)

BMI ( $\left.\mathbf{k g} / \mathbf{m}^{2}\right)$ : intervention 1: 28.0 (4.2); intervention 2: 27.0 (3.7); control: 28.0 (4.0)

Total cholesterol (mmol/L): intervention 1: 5.46 (1.18); intervention 2: 5.57 (1.03); control: 5.94 (1.11)

HDL cholesterol (mmol/L): intervention 1: 1.55 (0.40); intervention 2: 1.62 (0.40); control: 1.62 (0.48)

LDL cholesterol (mmol/L): intervention 1: 3.45 (1.03); intervention 2: 3.45 (0.89); control: 3.66 (0.98)

Triglycerides (mmol/L): intervention 1: 1.27 (0.68); intervention 2: 1.12 (0.54); control: 1.49 (0.86)

Blood pressure $(\mathbf{m m H g})$ : intervention 1: SBP 125.9 (1.4); DBP 75.7 (0.8); intervention 2: SBP 131.7 (1.4); DBP 78.4 (0.8); control: SBP 131.2 (1.4); DBP 79.1 (0.8)

Interventions Type: provision of foods high in fibre

Description: intervention 1: three servings of whole wheat foods ( $70 \mathrm{~g}$ to $80 \mathrm{~g}$ wholemeal bread and 30 $\mathrm{g}$ to $40 \mathrm{~g}$ whole grain cereals) (insoluble fibre). Intervention 2: one serving of whole wheat foods (35 $\mathrm{g}$ to $40 \mathrm{~g}$ wholemeal bread) and two servings of oats (60 $\mathrm{g}$ to $80 \mathrm{~g}$ of whole grain rolled oats) (soluble and insoluble fibre). Control: three servings of refined cereal foods (refined cereals and white bread). All instructed not to alter food intake apart from the trial changes and to maintain usual level of activity

\begin{tabular}{ll}
\hline Outcomes & BP, lipid levels \\
\hline Notes & $\begin{array}{l}\text { With thanks also to Dr Frank Theis for providing additional data for their trial (Tighe 2010 Wheat; Tighe } \\
2010 \text { Wheat+Oats ). }\end{array}$
\end{tabular}

\section{Risk of bias}

\begin{tabular}{lll}
\hline Bias & Authors' judgement & Support for judgement \\
\hline $\begin{array}{l}\text { Random sequence genera- } \\
\text { tion (selection bias) }\end{array}$ & Low risk & $\begin{array}{l}\text { Web-based randomisation system, random permuted blocks stratified by age, } \\
\text { gender and BMI }\end{array}$ \\
\hline $\begin{array}{l}\text { Allocation concealment } \\
\text { (selection bias) }\end{array}$ & Low risk & Off-site allocation \\
\hline $\begin{array}{l}\text { Blinding of participants } \\
\text { and personnel (perfor- } \\
\text { mance bias) } \\
\text { All outcomes }\end{array}$ & High risk & Single blind \\
\hline
\end{tabular}

Blinding of outcome as- Low risk Outcome assessors blind sessment (detection bias)

All outcomes

Incomplete outcome data High risk Numbers and reasons provided, difference between groups (attrition bias) 
Tighe 2010 Wheat (Continued)

All outcomes

Selective reporting (re- Unclear risk $\quad$ Blood pressure reported in Tighe 2010 paper, not 2013 paper
porting bias)

Other bias Unclear risk Not enough information to judge

Tighe 2010 Wheat+Oats

\begin{tabular}{|c|c|c|}
\hline Methods & \multicolumn{2}{|c|}{ see previous - study had three relevant study groups } \\
\hline \multicolumn{3}{|l|}{ Participants } \\
\hline \multicolumn{3}{|l|}{ Interventions } \\
\hline \multicolumn{3}{|l|}{ Outcomes } \\
\hline \multicolumn{3}{|l|}{ Notes } \\
\hline \multicolumn{3}{|l|}{ Risk of bias } \\
\hline Bias & Authors' judgement & Support for judgement \\
\hline $\begin{array}{l}\text { Random sequence genera- } \\
\text { tion (selection bias) }\end{array}$ & Low risk & see previous \\
\hline $\begin{array}{l}\text { Allocation concealment } \\
\text { (selection bias) }\end{array}$ & Low risk & see previous \\
\hline $\begin{array}{l}\text { Blinding of participants } \\
\text { and personnel (perfor- } \\
\text { mance bias) } \\
\text { All outcomes }\end{array}$ & High risk & see previous \\
\hline $\begin{array}{l}\text { Blinding of outcome as- } \\
\text { sessment (detection bias) } \\
\text { All outcomes }\end{array}$ & Low risk & see previous \\
\hline $\begin{array}{l}\text { Incomplete outcome data } \\
\text { (attrition bias) } \\
\text { All outcomes }\end{array}$ & High risk & see previous \\
\hline $\begin{array}{l}\text { Selective reporting (re- } \\
\text { porting bias) }\end{array}$ & Unclear risk & see previous \\
\hline Other bias & Unclear risk & see previous \\
\hline
\end{tabular}

Characteristics of excluded studies [ordered by study ID]

\begin{tabular}{ll}
\hline Study & Reason for exclusion \\
\hline Bays $2013 \quad$ Short term (six weeks) \\
\hline \\
\hline $\begin{array}{l}\text { Dietary fibre for the primary prevention of cardiovascular disease (Review) } \\
\text { Copyright } \odot 2016 \text { The Cochrane Collaboration. Published by John Wiley \& Sons, Ltd. }\end{array}$
\end{tabular}




\begin{tabular}{ll}
\hline Study & Reason for exclusion \\
\hline Davy 2002 & Control not no intervention or minimal intervention \\
\hline Dodson 1989 & Multifactorial intervention \\
\hline King 2008 & No relevant outcomes \\
\hline Liao 2007 & Short term (eight weeks) \\
\hline Mee 1997 & Short term (six weeks) \\
\hline Ramprasath 2014 & Multifactorial intervention \\
\hline Reid 2002 & Control not no intervention or minimal intervention \\
\hline Tapola 2008 & Short term (eight weeks) \\
\hline
\end{tabular}

\section{Characteristics of studies awaiting assessment [ordered by study ID]}

Keenan 2002b

\begin{tabular}{ll}
\hline Methods & Cost analysis of a parallel group RCT included in the review (Pins 2002) \\
\hline Participants & see Pins 2002 \\
\hline Interventions & see Pins 2002 \\
\hline Outcomes & see Pins 2002 \\
\hline Library unable to locate & Yes \\
\hline Notes & $\begin{array}{l}\text { This is the abstract from the database search: The management of hypertension has become an in- } \\
\text { creasing priority in managed care. While better control of blood pressure will lead to better health } \\
\text { and, we expect, lower costs in the future, the short term cost of antihypertensive medication are } \\
\text { here and now. In this report, Joseph Keenan and his colleagues demonstrate lower costs for antihy- } \\
\text { pertensive medication in patients randomly assigned to a diet rich in whole-grain fiber, compared } \\
\text { to controls. While it seems appropriate to call for further study and longer follow-up, these findings } \\
\text { could form the basis for much more cost-effective approaches to managing the hypertensive popu- } \\
\text { lation. }\end{array}$
\end{tabular}

Characteristics of ongoing studies [ordered by study ID]

\section{Lambert 2014}

Trial name or title

\begin{tabular}{ll}
\hline Methods & Parallel group RCT \\
\hline Participants & Stable body weight for at least three months, aged 18 years to 70 years, BMI between $25 \mathrm{~kg} / \mathrm{m}^{2}$ to \\
& $58 \mathrm{~kg} / \mathrm{m}^{2}$, no concomitant weight loss medication use, diet or exercise regime for weight loss, cor- \\
ticosteroids, antidepressants, anti-epileptics, lipid lowering or diabetes medications, previous \\
bariatric surgery or other intestinal surgery, pregnancy or lactation, use of bulk laxatives, probi-
\end{tabular}


Lambert 2014 (Continued)

otics, chronic antacid use, antibiotics, significant cardiovascular or respiratory disease, liver disease, alcohol or drug dependency, active malignancy, > $350 \mathrm{lb}$ weight
Twelve week intervention of food high in fibre

Biscuits containing $5 \mathrm{~g}$ of pea fibre per serving, three times per day within 30 minutes of daily meals. Dose slowly increased over the first three weeks of the study

Control group to have an isocaloric control biscuit with no pea fibre

\begin{tabular}{ll}
\hline Outcomes & Lipid levels \\
\hline Starting date & October 2012 \\
\hline Contact information & reimer@ucalgary.ca \\
\hline Notes & ClinicalTrials.gov (NCT01719900) Registered October 23, 2012. \\
\hline
\end{tabular}

\section{DATA AND ANALYSES}

\section{Comparison 1. Fibre versus control}

\begin{tabular}{|c|c|c|c|c|}
\hline Outcome or subgroup title & $\begin{array}{l}\text { No. of } \\
\text { studies }\end{array}$ & $\begin{array}{l}\text { No. of } \\
\text { partici- } \\
\text { pants }\end{array}$ & Statistical method & Effect size \\
\hline 1 Total Cholesterol mmol/L change & 20 & 1067 & Mean Difference (IV, Random, 95\% CI) & $-0.20[-0.34,-0.06]$ \\
\hline $2 \mathrm{HDL}$ Cholesterol mmol/L change & 18 & 982 & Mean Difference (IV, Fixed, 95\% CI) & $-0.03[-0.06,-0.01]$ \\
\hline 3 LDL Cholesterol mmol/L change & 18 & 995 & Mean Difference (IV, Fixed, 95\% CI) & $-0.14[-0.22,-0.06]$ \\
\hline 4 Triglycerides $\mathrm{mmol} / \mathrm{L}$ change & 18 & 982 & Mean Difference (IV, Fixed, 95\% CI) & $0.00[-0.04,0.05]$ \\
\hline $\begin{array}{l}5 \text { Systolic blood pressure }(\mathrm{mmHg}) \\
\text { change }\end{array}$ & 10 & 661 & Mean Difference (IV, Random, 95\% CI) & $-1.92[-4.02,0.19]$ \\
\hline $\begin{array}{l}6 \text { Diastolic blood pressure }(\mathrm{mmHg}) \\
\text { change }\end{array}$ & 10 & 661 & Mean Difference (IV, Fixed, 95\% CI) & $-1.77[-2.61,-0.92]$ \\
\hline
\end{tabular}

Analysis 1.1. Comparison 1 Fibre versus control, Outcome 1 Total Cholesterol mmol/L change.

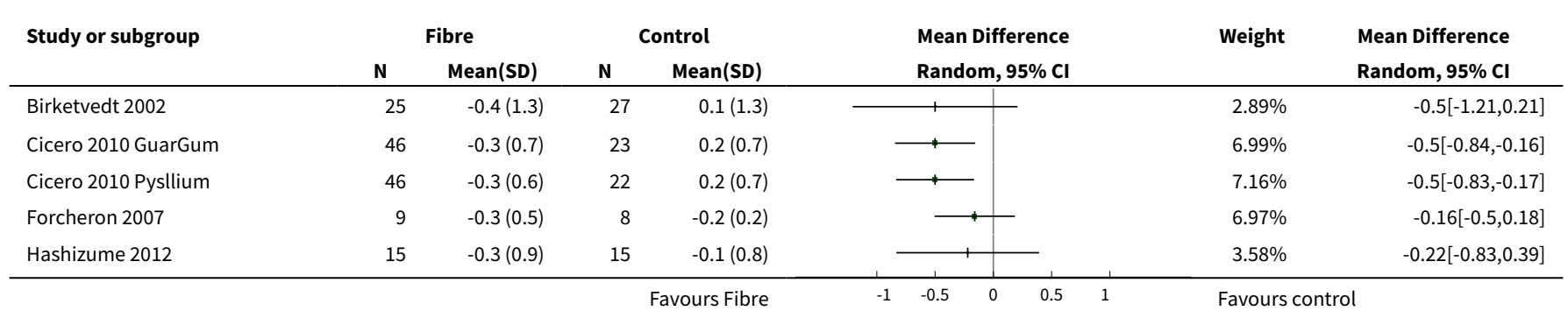




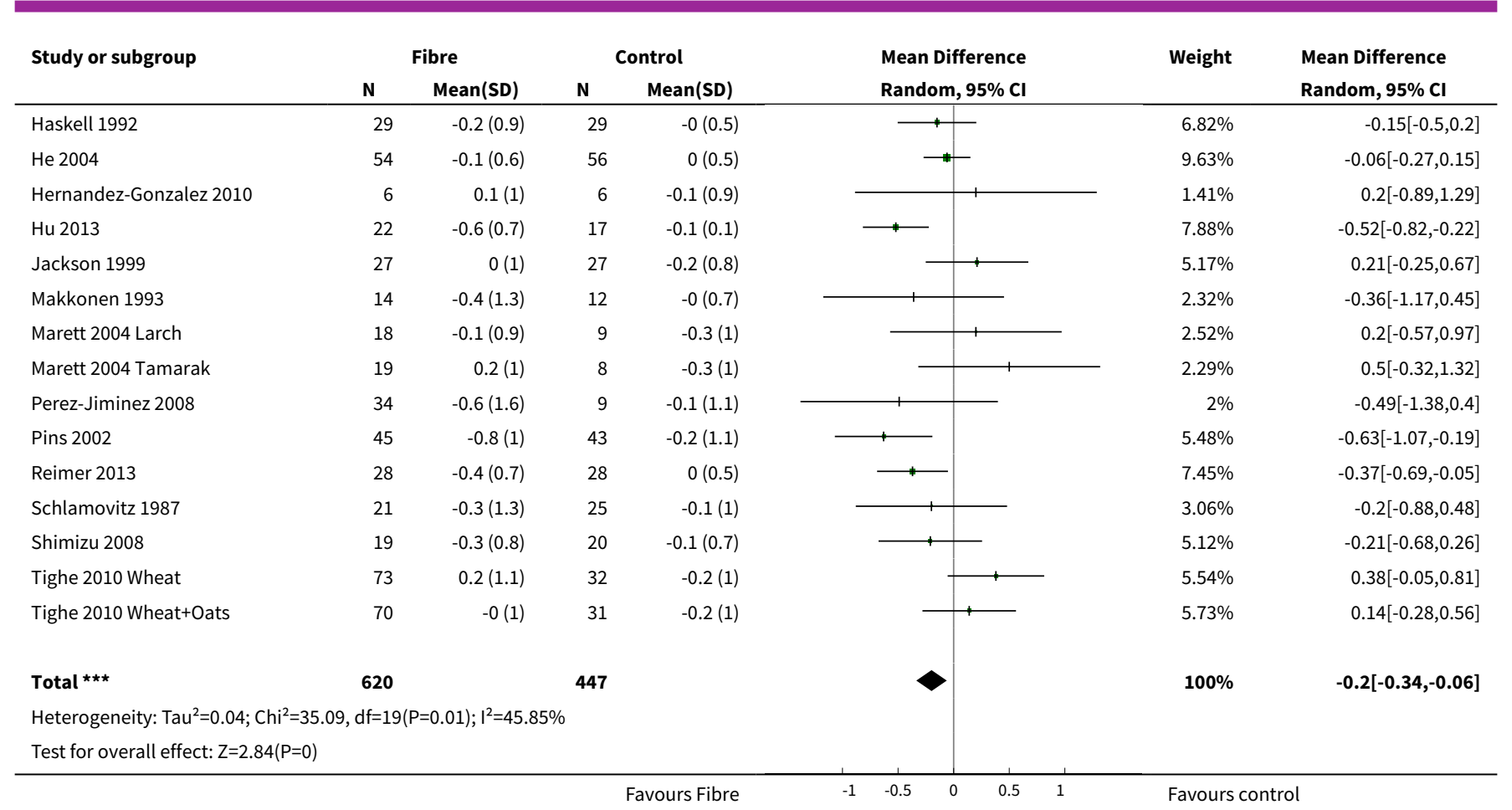

\section{Analysis 1.2. Comparison 1 Fibre versus control, Outcome $2 \mathrm{HDL}$ Cholesterol mmol/L change.}

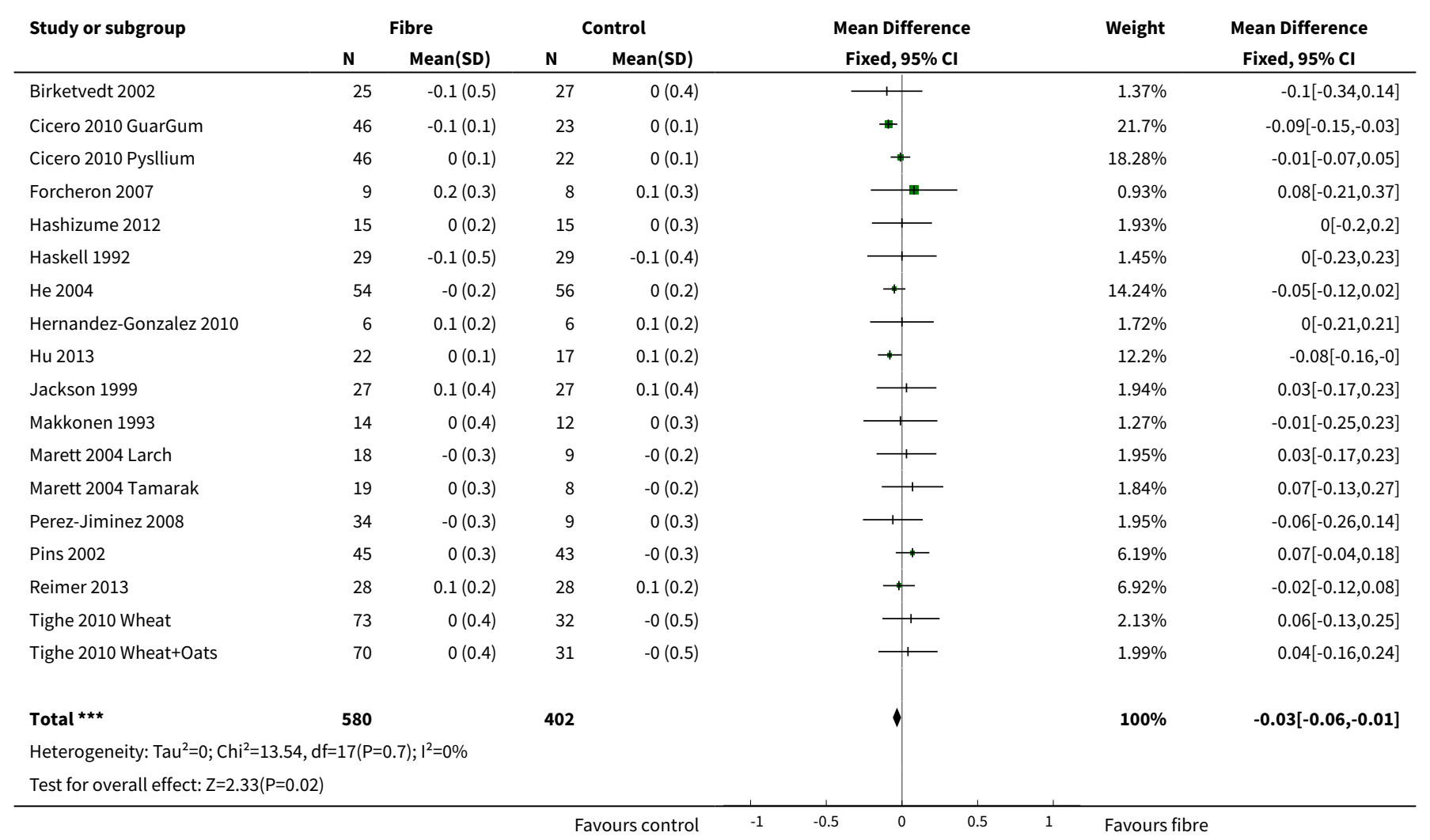


Analysis 1.3. Comparison 1 Fibre versus control, Outcome 3 LDL Cholesterol mmol/L change.

\begin{tabular}{|c|c|c|c|c|c|c|c|}
\hline \multirow[t]{2}{*}{ Study or subgroup } & \multicolumn{2}{|c|}{ Fibre } & \multicolumn{2}{|c|}{ Control } & \multirow{2}{*}{$\begin{array}{c}\text { Mean Difference } \\
\text { Fixed, } 95 \% \mathrm{Cl}\end{array}$} & \multirow[t]{2}{*}{ Weight } & \multirow{2}{*}{$\begin{array}{c}\text { Mean Difference } \\
\text { Fixed, } 95 \% \mathrm{Cl}\end{array}$} \\
\hline & $\mathbf{N}$ & Mean(SD) & $\mathbf{N}$ & Mean(SD) & & & \\
\hline Birketvedt 2002 & 25 & $0.3(1)$ & 27 & $0(1.3)$ & 1, & $1.63 \%$ & $0.3[-0.32,0.92]$ \\
\hline Cicero 2010 GuarGum & 46 & $-0.3(0.4)$ & 23 & $-0.1(0.4)$ & + & $14.65 \%$ & $-0.2[-0.41,0.01]$ \\
\hline Cicero 2010 Pysllium & 46 & $-0.2(0.3)$ & 22 & $-0.1(0.4)$ & $\rightarrow$ & $15.3 \%$ & $-0.1[-0.3,0.1]$ \\
\hline Forcheron 2007 & 9 & $-0.5(0.5)$ & 8 & $-0.2(0.8)$ & \begin{tabular}{l|l}
1 \\
\end{tabular} & $1.53 \%$ & $-0.31[-0.95,0.33]$ \\
\hline Hashizume 2012 & 15 & $-0.3(0.9)$ & 15 & $-0.1(0.8)$ & - & $1.67 \%$ & $-0.21[-0.83,0.41]$ \\
\hline He 2004 & 54 & $-0(0.5)$ & 56 & $-0(0.5)$ & + & $19.52 \%$ & $-0.03[-0.21,0.15]$ \\
\hline Hernandez-Gonzalez 2010 & 6 & $-0.2(0.8)$ & 6 & $0(0.9)$ & * & $0.73 \%$ & $-0.2[-1.13,0.73]$ \\
\hline Hu 2013 & 22 & $-0.4(0.7)$ & 17 & $0.2(0.3)$ & $\rightarrow$ & $5.97 \%$ & $-0.63[-0.96,-0.3]$ \\
\hline Jackson 1999 & 27 & $-0.1(0.8)$ & 27 & $-0.3(0.9)$ & $\longleftarrow$ & $2.92 \%$ & $0.19[-0.28,0.66]$ \\
\hline Marett 2004 Larch & 18 & $-0.3(0.9)$ & 9 & $-0.2(0.8)$ & & $1.42 \%$ & $-0.12[-0.79,0.55]$ \\
\hline Marett 2004 Tamarak & 19 & $0.1(0.9)$ & 8 & $-0.2(0.8)$ & \begin{tabular}{l|l}
-1 \\
\end{tabular} & $1.3 \%$ & $0.32[-0.38,1.02]$ \\
\hline Pins 2002 & 45 & $-0.6(0.8)$ & 43 & $-0.2(0.8)$ & 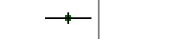 & $6.18 \%$ & $-0.42[-0.74,-0.1]$ \\
\hline Reimer 2013 & 28 & $-0.4(0.6)$ & 28 & $-0.1(0.5)$ & $\rightarrow-$ & $7.56 \%$ & $-0.36[-0.65,-0.07]$ \\
\hline Shimizu 2008 & 19 & $-0.1(0.6)$ & 20 & $-0(0.6)$ & + & $4.04 \%$ & $-0.13[-0.53,0.27]$ \\
\hline Tighe 2010 Wheat & 73 & $0.1(0.9)$ & 32 & $-0.2(0.9)$ & + & $4.33 \%$ & $0.22[-0.16,0.6]$ \\
\hline Tighe 2010 Wheat+Oats & 70 & $-0.1(0.9)$ & 31 & $-0.2(0.9)$ & 1 & $4.44 \%$ & $0.06[-0.32,0.44]$ \\
\hline 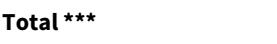 & 585 & & 410 & & $\checkmark$ & $100 \%$ & $-0.14[-0.22,-0.06]$ \\
\hline \multicolumn{8}{|c|}{ Heterogeneity: $\mathrm{Tau}^{2}=0 ; \mathrm{Chi}^{2}=26.37, \mathrm{df}=17(\mathrm{P}=0.07) ; \mathrm{I}^{2}=35.52 \%$} \\
\hline Test for overall effect: $Z=3.4$ & & & & & & & \\
\hline
\end{tabular}

Analysis 1.4. Comparison 1 Fibre versus control, Outcome 4 Triglycerides $\mathrm{mmol} / \mathrm{L}$ change.

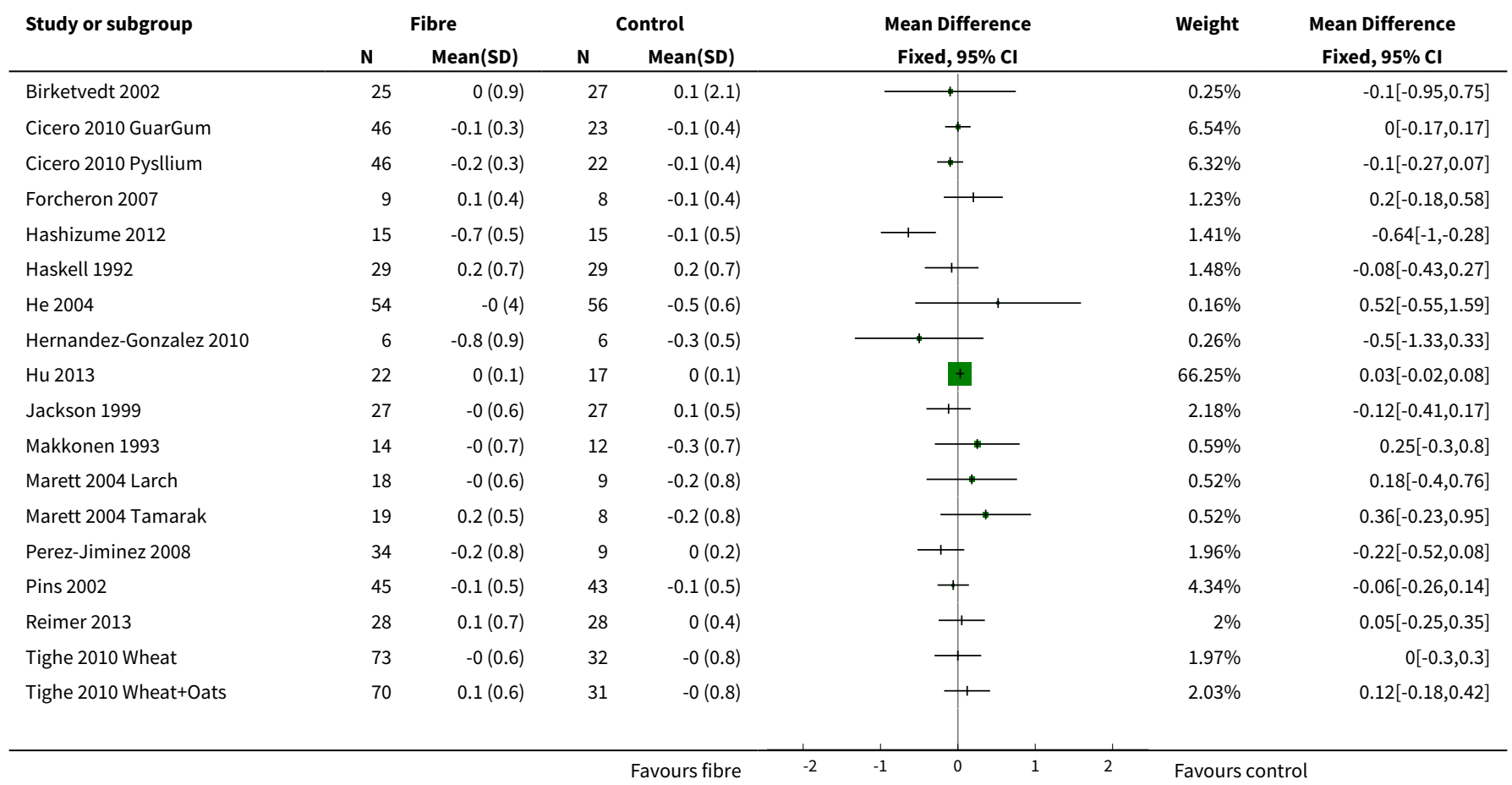




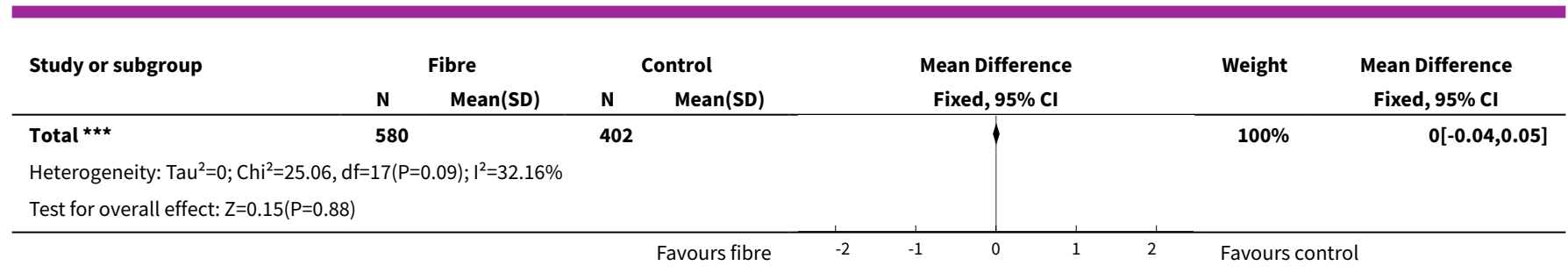

\section{Analysis 1.5. Comparison 1 Fibre versus control, Outcome 5 Systolic blood pressure ( $\mathrm{mmHg}$ ) change.}

\begin{tabular}{|c|c|c|c|c|c|c|c|}
\hline \multirow[t]{2}{*}{ Study or subgroup } & \multicolumn{2}{|c|}{ Fibre } & \multicolumn{2}{|c|}{ Control } & \multirow{2}{*}{$\begin{array}{l}\text { Mean Difference } \\
\text { Random, } 95 \% \mathrm{Cl}\end{array}$} & \multirow[t]{2}{*}{ Weight } & \multirow{2}{*}{$\begin{array}{l}\text { Mean Difference } \\
\text { Random, } 95 \% \mathrm{Cl}\end{array}$} \\
\hline & $\mathbf{N}$ & Mean(SD) & $\mathbf{N}$ & Mean(SD) & & & \\
\hline Cicero 2010 GuarGum & 46 & $-3.4(3.9)$ & 23 & $-1(3.8)$ & $\rightarrow-$ & $16.24 \%$ & $-2.4[-4.31,-0.49]$ \\
\hline Cicero 2010 Pysllium & 46 & $-5.2(3.9)$ & 22 & $-1(3.8)$ & $\rightarrow$ & $16.15 \%$ & $-4.2[-6.15,-2.25]$ \\
\hline He 2004 & 54 & $-3.4(7.3)$ & 56 & $-1.6(6.2)$ & $\rightarrow$ & $14.74 \%$ & $-1.8[-4.34,0.74]$ \\
\hline Hu 2013 & 22 & $-1.2(2.5)$ & 17 & $-2.6(3.7)$ & + & $15.93 \%$ & $1.46[-0.59,3.51]$ \\
\hline Makkonen 1993 & 15 & $-3.1(20.2)$ & 13 & $-8.9(13.2)$ & & $2.46 \%$ & $5.82[-6.67,18.31]$ \\
\hline Reimer 2013 & 28 & $-2.6(7.9)$ & 28 & $-6.4(10.6)$ & $\rightarrow$ & $9.3 \%$ & $3.8[-1.1,8.7]$ \\
\hline Schlamovitz 1987 & 21 & $-10(15.4)$ & 25 & $1(12.1)$ & & $4.95 \%$ & $-11[-19.12,-2.88]$ \\
\hline Tighe 2010 Wheat & 71 & $-4.9(11.7)$ & 32 & $-1.1(13)$ & * & $8.65 \%$ & $-3.79[-9.04,1.46]$ \\
\hline Tighe 2010 Wheat+Oats & 68 & $-6.1(12.2)$ & 31 & $-1.1(13)$ & $\longrightarrow$ & $8.37 \%$ & $-4.99[-10.4,0.42]$ \\
\hline 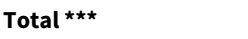 & 405 & & 256 & & & $100 \%$ & $-1.92[-4.02,0.19]$ \\
\hline \multicolumn{3}{|c|}{ Test for overall effect: $Z=1.79(P=0.07)$} & & & & & \\
\hline
\end{tabular}

\section{Analysis 1.6. Comparison 1 Fibre versus control, Outcome 6 Diastolic blood pressure $(\mathrm{mmHg})$ change.}

\begin{tabular}{|c|c|c|c|c|c|c|c|}
\hline \multirow[t]{2}{*}{ Study or subgroup } & \multicolumn{2}{|c|}{ Fibre } & \multicolumn{2}{|c|}{ Control } & \multirow{2}{*}{$\begin{array}{c}\text { Mean Difference } \\
\text { Fixed, } 95 \% \mathrm{Cl}\end{array}$} & \multirow[t]{2}{*}{ Weight } & \multirow{2}{*}{$\begin{array}{c}\text { Mean Difference } \\
\text { Fixed, } 95 \% \mathrm{Cl}\end{array}$} \\
\hline & $\mathbf{N}$ & $\operatorname{Mean}(S D)$ & $\mathbf{N}$ & $\operatorname{Mean}(S D)$ & & & \\
\hline Cicero 2010 GuarGum & 46 & $-1.8(3.6)$ & 23 & $-0.7(4)$ & $\rightarrow$ & $19.51 \%$ & $-1.1[-3.01,0.81]$ \\
\hline Cicero 2010 Pysllium & 46 & $-2.2(3.9)$ & 22 & $-0.7(4)$ & $\rightarrow$ & $17.9 \%$ & $-1.5[-3.5,0.5]$ \\
\hline He 2004 & 54 & $-2.2(7.9)$ & 56 & $-1.1(5)$ & $\rightarrow$ & $11.6 \%$ & $-1.1[-3.58,1.38]$ \\
\hline Hu 2013 & 22 & $-4.8(2.7)$ & 17 & $-1.1(2.6)$ & $\#$ & $25.49 \%$ & $-3.69[-5.36,-2.02]$ \\
\hline Makkonen 1993 & 15 & $-1.5(11)$ & 13 & $-1.1(7.4)$ & & $1.51 \%$ & $-0.36[-7.25,6.53]$ \\
\hline Reimer 2013 & 28 & $-2.2(5.8)$ & 28 & $-3.6(7.9)$ & $\longleftarrow$ & $5.42 \%$ & $1.4[-2.23,5.03]$ \\
\hline Schlamovitz 1987 & 21 & $-5(9.6)$ & 25 & $-2(10.6)$ & - & $2.1 \%$ & $-3[-8.83,2.83]$ \\
\hline Tighe 2010 Wheat & 71 & $-1.7(7.7)$ & 32 & $-0.9(7.1)$ & $\rightarrow$ & $7.74 \%$ & $-0.8[-3.84,2.24]$ \\
\hline Tighe 2010 Wheat+Oats & 68 & $-2.5(7.1)$ & 31 & $-0.9(7.1)$ & $\rightarrow$ & $7.89 \%$ & $-1.64[-4.65,1.37]$ \\
\hline Total $* \star \star$ & 405 & & 256 & & $\checkmark$ & $100 \%$ & $-1.77[-2.61,-0.92]$ \\
\hline \multicolumn{3}{|c|}{ Test for overall effect: $Z=4.1(P<0.0001)$} & & & & & \\
\hline
\end{tabular}




\section{Comparison 2. Subgroup analyses}

\begin{tabular}{|c|c|c|c|c|}
\hline Outcome or subgroup title & $\begin{array}{l}\text { No. of } \\
\text { studies }\end{array}$ & $\begin{array}{l}\text { No. of } \\
\text { partici- } \\
\text { pants }\end{array}$ & Statistical method & Effect size \\
\hline $\begin{array}{l}1 \text { Total cholesterol } \mathrm{mmol} / \mathrm{L} \\
\text { change }\end{array}$ & 20 & 1067 & Mean Difference (IV, Random, 95\% CI) & $-0.20[-0.34,-0.06]$ \\
\hline $\begin{array}{l}\text { 1.1 Type of intervention - fi- } \\
\text { bre supplement }\end{array}$ & 13 & 555 & Mean Difference (IV, Random, 95\% CI) & $-0.24[-0.39,-0.09]$ \\
\hline $\begin{array}{l}\text { 1.2 Type of Intervention - } \\
\text { provision of foods }\end{array}$ & 7 & 512 & Mean Difference (IV, Random, 95\% CI) & $-0.16[-0.42,0.09]$ \\
\hline $\begin{array}{l}2 \mathrm{HDL} \text { Cholesterol mmol/L } \\
\text { change }\end{array}$ & 18 & 982 & Mean Difference (IV, Fixed, 95\% Cl) & $-0.03[-0.06,-0.01]$ \\
\hline $\begin{array}{l}2.1 \text { Type of intervention - fi- } \\
\text { bre supplement }\end{array}$ & 12 & 509 & Mean Difference (IV, Fixed, 95\% Cl) & $-0.04[-0.07,-0.00]$ \\
\hline $\begin{array}{l}2.2 \text { Type of intervention - } \\
\text { provision of foods }\end{array}$ & 6 & 473 & Mean Difference (IV, Fixed, 95\% Cl) & $-0.03[-0.07,0.02]$ \\
\hline $\begin{array}{l}3 \mathrm{LDL} \text { Cholesterol } \mathrm{mmol} / \mathrm{L} \\
\text { change }\end{array}$ & 18 & 995 & Mean Difference (IV, Fixed, 95\% Cl) & $-0.14[-0.22,-0.06]$ \\
\hline $\begin{array}{l}\text { 3.1 Type of Intervention - fi- } \\
\text { bre supplement }\end{array}$ & 11 & 483 & Mean Difference (IV, Fixed, 95\% Cl) & $-0.13[-0.24,-0.03]$ \\
\hline $\begin{array}{l}\text { 3.2 Type of Intervention - } \\
\text { provision of foods }\end{array}$ & 7 & 512 & Mean Difference (IV, Fixed, 95\% CI) & $-0.14[-0.26,-0.03]$ \\
\hline $\begin{array}{l}4 \text { Triglycerides } \mathrm{mmol} / \mathrm{L} \\
\text { change }\end{array}$ & 18 & 982 & Mean Difference (IV, Fixed, 95\% Cl) & $0.00[-0.04,0.05]$ \\
\hline $\begin{array}{l}\text { 4.1 Type of Intervention - fi- } \\
\text { bre supplement }\end{array}$ & 12 & 509 & Mean Difference (IV, Fixed, 95\% Cl) & $-0.03[-0.12,0.05]$ \\
\hline $\begin{array}{l}\text { 4.2 Type of Intervention - } \\
\text { provision of foods }\end{array}$ & 6 & 473 & Mean Difference (IV, Fixed, 95\% CI) & $0.02[-0.03,0.06]$ \\
\hline $\begin{array}{l}5 \text { Systolic blood pressure } \\
(\mathrm{mmHg}) \text { change }\end{array}$ & 10 & 661 & Mean Difference (IV, Random, 95\% Cl) & $-1.92[-4.02,0.19]$ \\
\hline $\begin{array}{l}5.1 \text { Type of intervention - fi- } \\
\text { bre supplement }\end{array}$ & 6 & 310 & Mean Difference (IV, Random, 95\% CI) & $-2.14[-5.19,0.91]$ \\
\hline $\begin{array}{l}5.2 \text { Type of intervention - } \\
\text { provision of foods }\end{array}$ & 4 & 351 & Mean Difference (IV, Random, 95\% Cl) & $-1.57[-4.45,1.31]$ \\
\hline $\begin{array}{l}6 \text { Diastolic blood pressure } \\
(\mathrm{mmHg}) \text { change }\end{array}$ & 10 & 653 & Mean Difference (IV, Fixed, 95\% Cl) & $-1.77[-2.62,-0.92]$ \\
\hline $\begin{array}{l}6.1 \text { Type of intervention - fi- } \\
\text { bre supplement }\end{array}$ & 6 & 310 & Mean Difference (IV, Fixed, 95\% Cl) & $-1.07[-2.30,0.16]$ \\
\hline $\begin{array}{l}\text { 6.2 Type of intervention - } \\
\text { provision of foods }\end{array}$ & 4 & 343 & Mean Difference (IV, Fixed, 95\% Cl) & $-2.40[-3.57,-1.23]$ \\
\hline
\end{tabular}




\begin{tabular}{|c|c|c|c|c|}
\hline Outcome or subgroup title & $\begin{array}{l}\text { No. of } \\
\text { studies }\end{array}$ & $\begin{array}{l}\text { No. of } \\
\text { partici- } \\
\text { pants }\end{array}$ & Statistical method & Effect size \\
\hline $\begin{array}{l}7 \text { Total cholesterol } \mathrm{mmol} / \mathrm{L} \\
\text { change }\end{array}$ & 20 & 1067 & Mean Difference (IV, Random, 95\% CI) & $-0.20[-0.34,-0.06]$ \\
\hline 7.1 Type of fibre - soluble & 14 & 688 & Mean Difference (IV, Random, 95\% CI) & $-0.22[-0.37,-0.07]$ \\
\hline 7.2 Type of fibre - insoluble & 3 & 187 & Mean Difference (IV, Random, 95\% CI) & $-0.03[-0.53,0.47]$ \\
\hline $\begin{array}{l}\text { 7.3 Type of fibre - soluble } \\
\text { and insoluble }\end{array}$ & 3 & 192 & Mean Difference (IV, Random, 95\% CI) & $-0.28[-0.75,0.19]$ \\
\hline $\begin{array}{l}8 \mathrm{HDL} \text { Cholesterol } \mathrm{mmol} / \mathrm{L} \\
\text { change }\end{array}$ & 18 & 982 & Mean Difference (IV, Fixed, 95\% CI) & $-0.03[-0.06,-0.01]$ \\
\hline 8.1 Type of fibre - soluble & 13 & 642 & Mean Difference (IV, Fixed, 95\% CI) & $-0.03[-0.06,0.00]$ \\
\hline 8.2 Type of fibre - insoluble & 2 & 148 & Mean Difference (IV, Fixed, 95\% CI) & $0.00[-0.13,0.14]$ \\
\hline $\begin{array}{l}8.3 \text { Type of fibre - soluble } \\
\text { and insoluble }\end{array}$ & 3 & 192 & Mean Difference (IV, Fixed, 95\% CI) & $-0.07[-0.14,0.00]$ \\
\hline $\begin{array}{l}9 \mathrm{LDL} \text { Cholesterol } \mathrm{mmol} / \mathrm{L} \\
\text { change }\end{array}$ & 18 & 995 & Mean Difference (IV, Fixed, 95\% CI) & $-0.14[-0.22,-0.06]$ \\
\hline 9.1 Type of fibre - soluble & 12 & 616 & Mean Difference (IV, Fixed, 95\% CI) & $-0.14[-0.23,-0.05]$ \\
\hline 9.2 Type of fibre - insoluble & 3 & 187 & Mean Difference (IV, Fixed, 95\% CI) & $0.01[-0.24,0.27]$ \\
\hline $\begin{array}{l}\text { 9.3 Type of fibre - soluble } \\
\text { and insoluble }\end{array}$ & 3 & 192 & Mean Difference (IV, Fixed, 95\% CI) & $-0.25[-0.48,-0.02]$ \\
\hline $\begin{array}{l}10 \text { Triglycerides } \mathrm{mmol} / \mathrm{L} \\
\text { change }\end{array}$ & 18 & 982 & Mean Difference (IV, Fixed, 95\% CI) & $0.00[-0.04,0.05]$ \\
\hline 10.1 Type of fibre - soluble & 13 & 642 & Mean Difference (IV, Fixed, 95\% CI) & $-0.05[-0.13,0.03]$ \\
\hline 10.2 Type of fibre - insoluble & 2 & 148 & Mean Difference (IV, Fixed, 95\% CI) & $-0.11[-0.32,0.10]$ \\
\hline $\begin{array}{l}10.3 \text { Type of fibre - soluble } \\
\text { and insoluble }\end{array}$ & 3 & 192 & Mean Difference (IV, Fixed, 95\% CI) & $0.03[-0.02,0.08]$ \\
\hline $\begin{array}{l}11 \text { Systolic blood pressure } \\
(\mathrm{mmHg}) \text { change }\end{array}$ & 10 & 661 & Mean Difference (IV, Random, 95\% CI) & $-1.92[-4.02,0.19]$ \\
\hline 11.1 Type of fibre - soluble & 6 & 377 & Mean Difference (IV, Random, 95\% Cl) & $-2.19[-4.66,0.28]$ \\
\hline 11.2 Type of fibre -insoluble & 2 & 146 & Mean Difference (IV, Random, 95\% CI) & $-3.19[-7.91,1.52]$ \\
\hline $\begin{array}{l}11.3 \text { Type of fibre - soluble } \\
\text { and insoluble }\end{array}$ & 2 & 138 & Mean Difference (IV, Random, 95\% CI) & $-1.26[-7.50,4.98]$ \\
\hline $\begin{array}{l}12 \text { Diastolic blood pressure } \\
(\mathrm{mmHg}) \text { change }\end{array}$ & 10 & 661 & Mean Difference (IV, Fixed, 95\% CI) & $-1.77[-2.61,-0.92]$ \\
\hline 12.1 Type of fibre - soluble & 6 & 377 & Mean Difference (IV, Fixed, 95\% CI) & $-1.04[-2.15,0.07]$ \\
\hline
\end{tabular}




\begin{tabular}{lllll}
\hline Outcome or subgroup title & $\begin{array}{l}\text { No. of } \\
\text { studies }\end{array}$ & $\begin{array}{l}\text { No. of } \\
\text { partici- } \\
\text { pants }\end{array}$ & Statistical method & Effect size \\
\hline 12.2 Type of fibre -insoluble & 2 & 146 & Mean Difference (IV, Fixed, 95\% Cl) & $-1.09[-3.97,1.79]$ \\
\hline $\begin{array}{l}12.3 \text { Type of fibre - soluble } \\
\text { and insoluble }\end{array}$ & 2 & 138 & Mean Difference (IV, Fixed, 95\% Cl) & $-3.21[-4.67,-1.74]$ \\
\hline
\end{tabular}

\section{Analysis 2.1. Comparison 2 Subgroup analyses, Outcome 1 Total cholesterol $\mathrm{mmol} / \mathrm{L}$ change.}

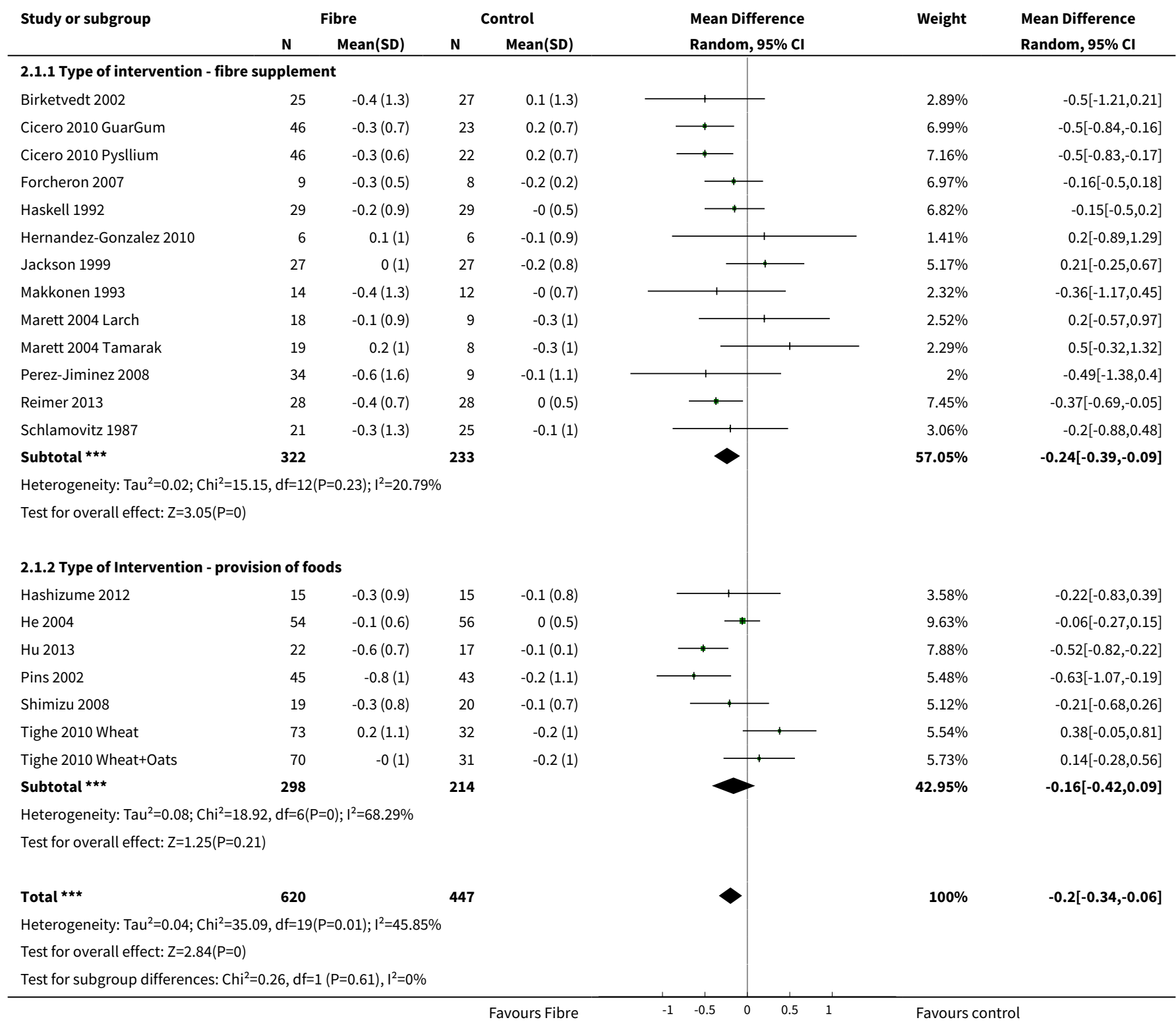


Analysis 2.2. Comparison 2 Subgroup analyses, Outcome $2 \mathrm{HDL}$ Cholesterol mmol/L change.

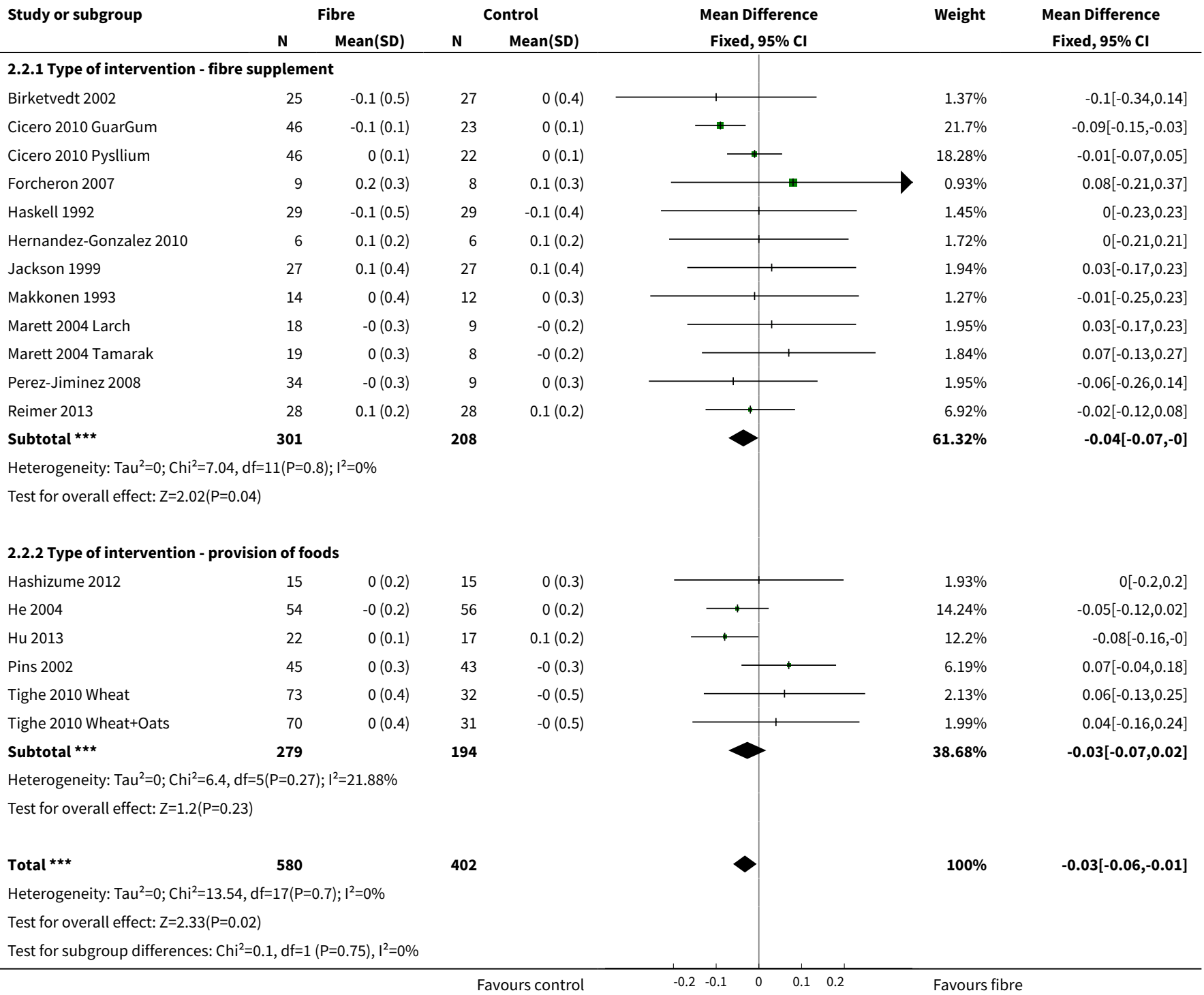

\section{Analysis 2.3. Comparison 2 Subgroup analyses, Outcome 3 LDL Cholesterol mmol/L change.}

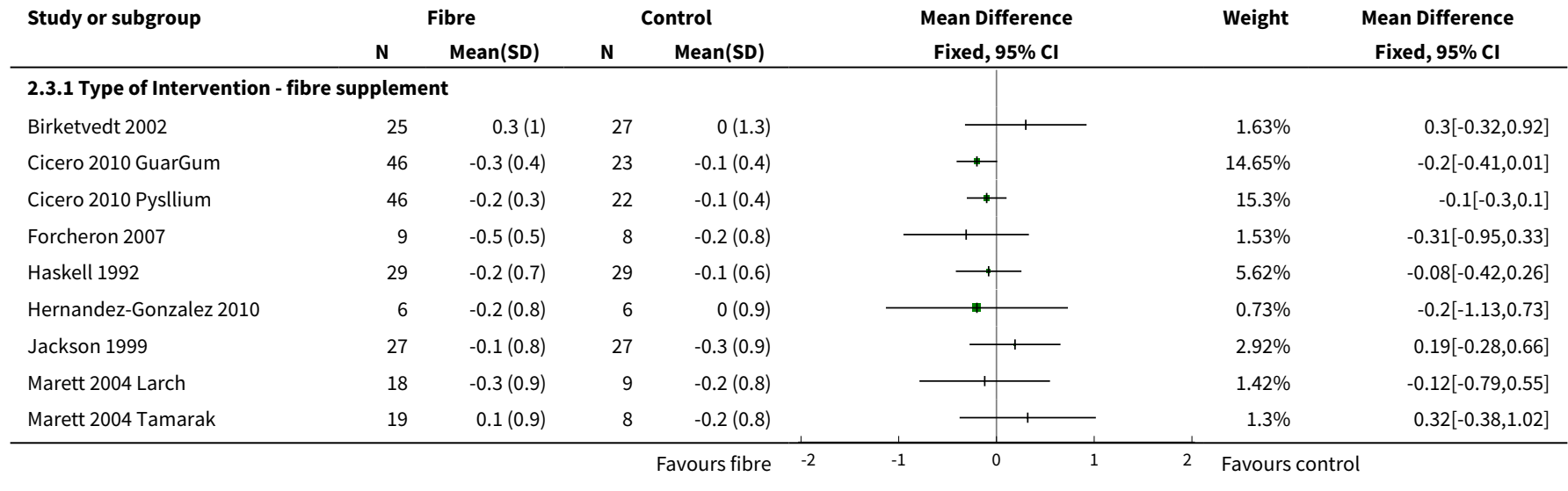




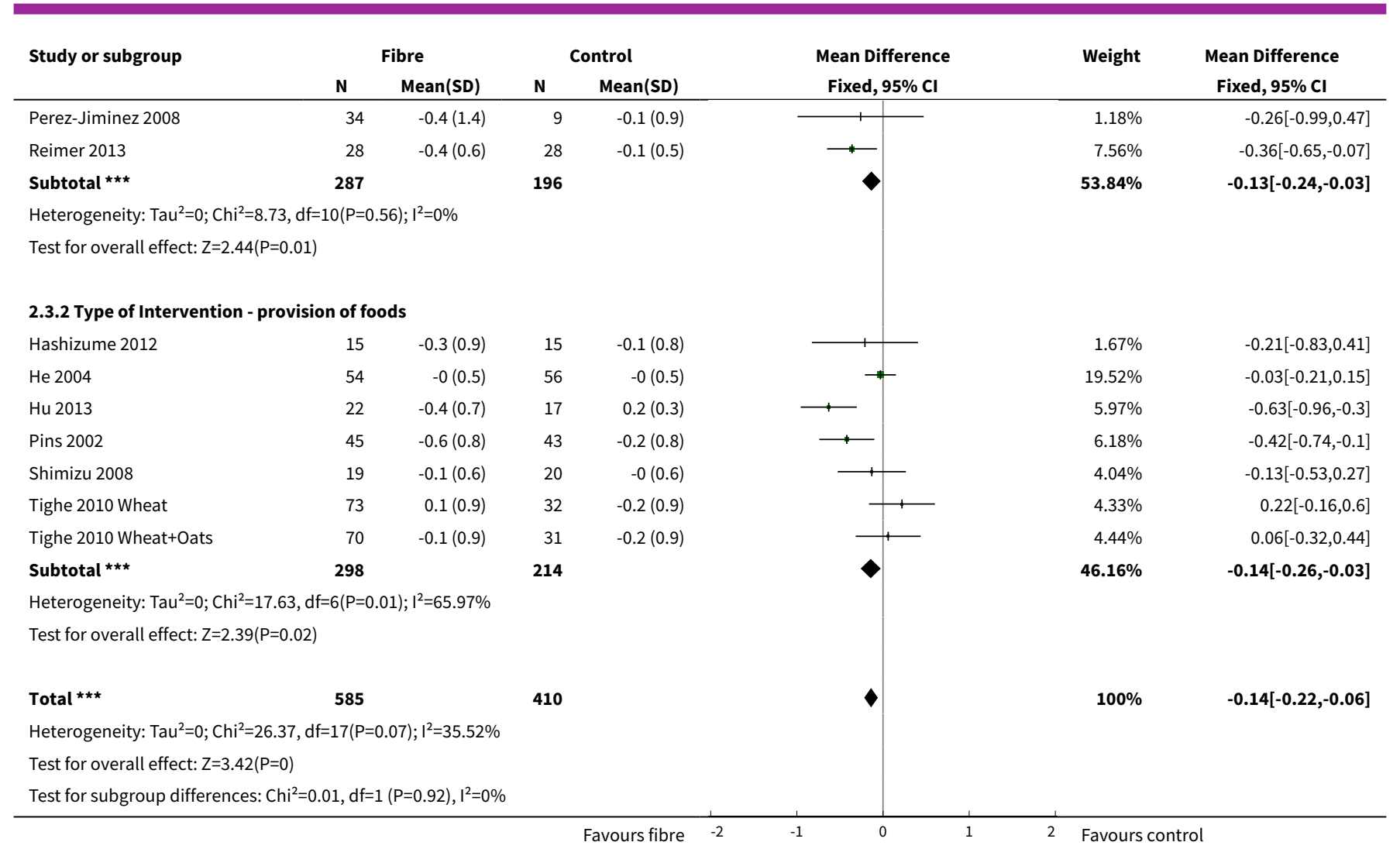

Analysis 2.4. Comparison 2 Subgroup analyses, Outcome 4 Triglycerides mmol/L change.

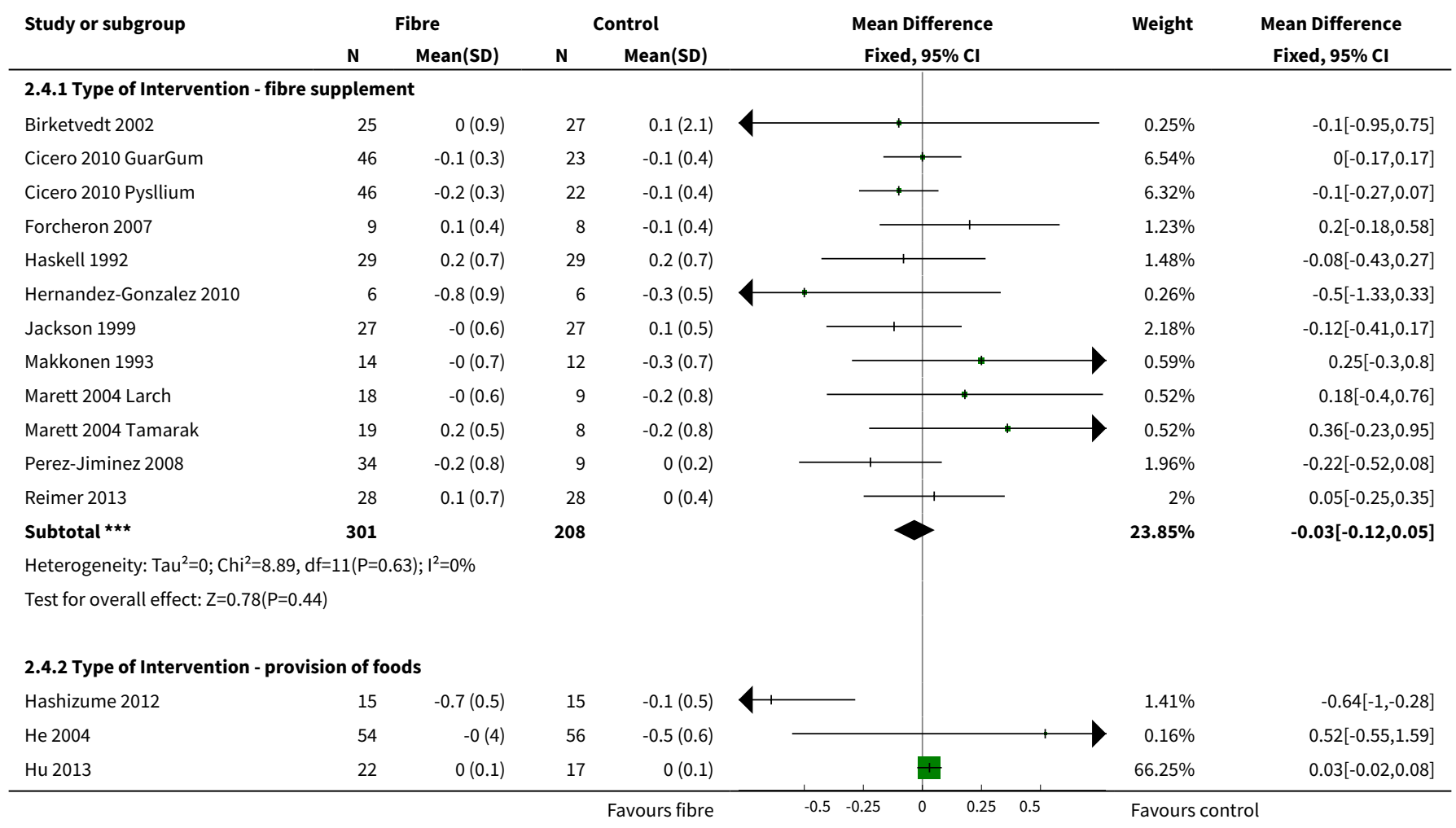




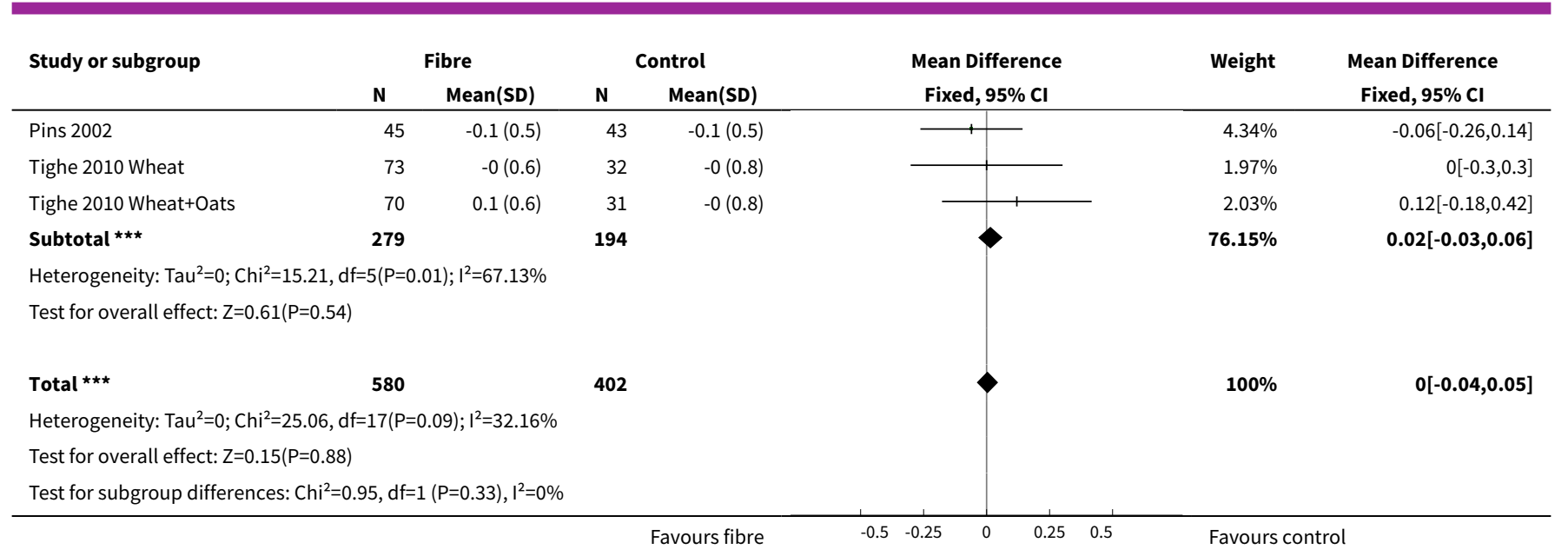

Analysis 2.5. Comparison 2 Subgroup analyses, Outcome 5 Systolic blood pressure $(\mathrm{mmHg})$ change.

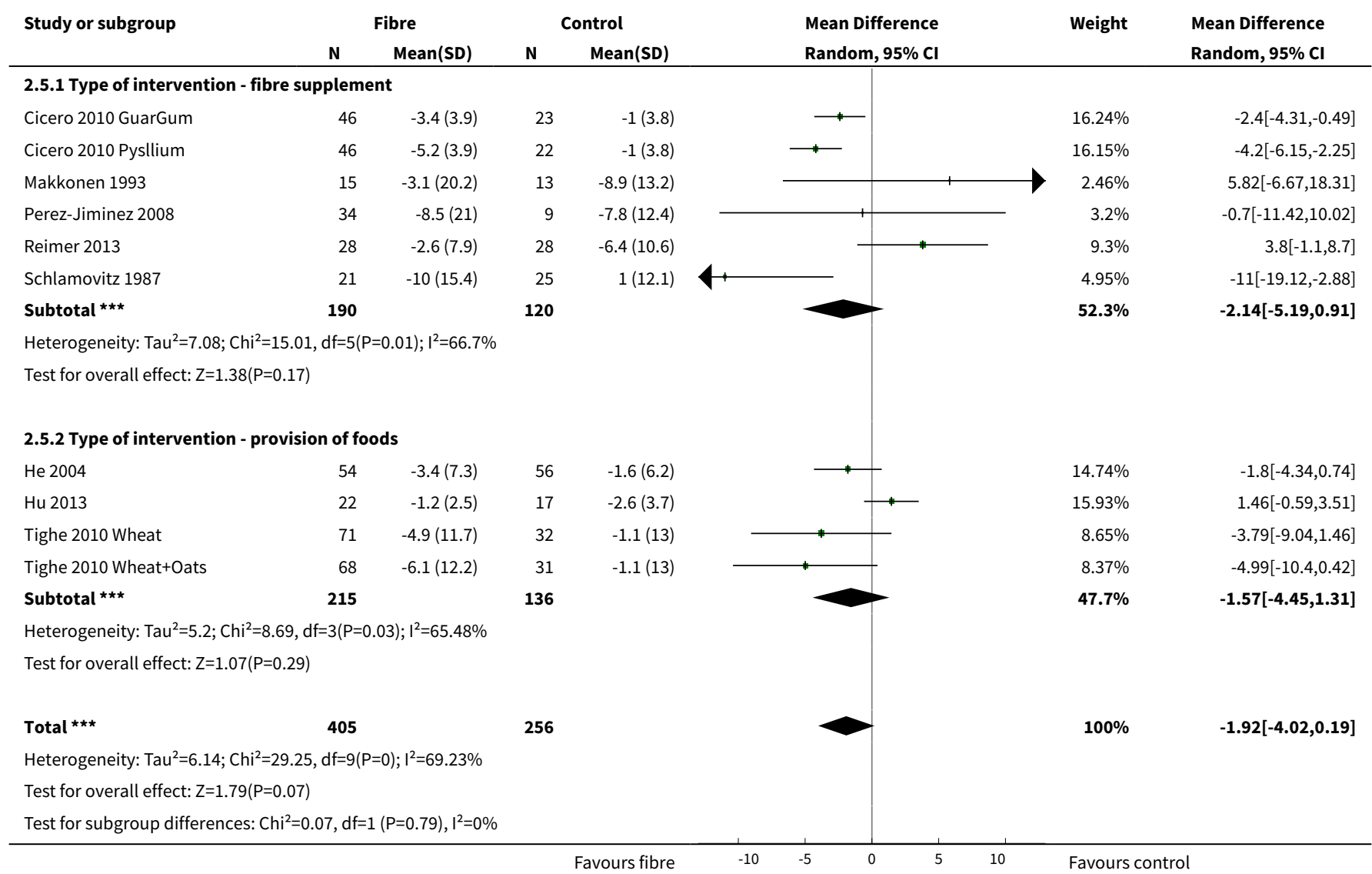


Analysis 2.6. Comparison 2 Subgroup analyses, Outcome 6 Diastolic blood pressure $(\mathrm{mmHg})$ change.

\begin{tabular}{|c|c|c|c|c|c|c|c|}
\hline \multirow[t]{2}{*}{ Study or subgroup } & \multicolumn{2}{|c|}{ Fibre } & \multicolumn{2}{|c|}{ Control } & \multirow{2}{*}{$\begin{array}{c}\text { Mean Difference } \\
\text { Fixed, } 95 \% \mathrm{Cl}\end{array}$} & \multirow[t]{2}{*}{ Weight } & \multirow{2}{*}{$\begin{array}{c}\text { Mean Difference } \\
\text { Fixed, } 95 \% \mathrm{Cl}\end{array}$} \\
\hline & $\mathbf{N}$ & $\operatorname{Mean}(S D)$ & $\mathbf{N}$ & $\operatorname{Mean}(S D)$ & & & \\
\hline \multicolumn{8}{|c|}{ 2.6.1 Type of intervention - fibre supplement } \\
\hline Cicero 2010 GuarGum & 46 & $-1.8(3.6)$ & 23 & $-0.7(4)$ & $\because$ & $19.57 \%$ & $-1.1[-3.01,0.81]$ \\
\hline Cicero 2010 Pysllium & 46 & $-2.2(3.9)$ & 22 & $-0.7(4)$ & & $17.96 \%$ & $-1.5[-3.5,0.5]$ \\
\hline Makkonen 1993 & 15 & $-1.5(11)$ & 13 & $-1.1(7.4)$ & & $1.51 \%$ & $-0.36[-7.25,6.53]$ \\
\hline Perez-Jiminez 2008 & 34 & $-3.8(11.9)$ & 9 & $-0.1(12.6)$ & $\Rightarrow$ & $0.86 \%$ & $-3.7[-12.83,5.43]$ \\
\hline Schlamovitz 1987 & 21 & $-5(9.6)$ & 25 & $-2(10.6)$ & & $2.11 \%$ & $-3[-8.83,2.83]$ \\
\hline Subtotal ${ }^{\star \star \star}$ & 190 & & 120 & & & $47.44 \%$ & $-1.07[-2.3,0.16]$ \\
\hline \multicolumn{8}{|c|}{ Heterogeneity: $\mathrm{Tau}^{2}=0 ; \mathrm{Chi}^{2}=2.74, \mathrm{df}=5(\mathrm{P}=0.74) ; \mathrm{I}^{2}=0 \%$} \\
\hline \multicolumn{8}{|c|}{ Test for overall effect: $Z=1.71(P=0.09)$} \\
\hline \multicolumn{8}{|c|}{ 2.6.2 Type of intervention - provision of foods } \\
\hline Hu 2013 & 22 & $-4.8(2.7)$ & 17 & $-1.1(2.6)$ & $\longrightarrow$ & $25.57 \%$ & $-3.69[-5.36,-2.02]$ \\
\hline Tighe 2010 Wheat & 63 & $-1.7(7.7)$ & 32 & $-0.9(7.1)$ & & $7.44 \%$ & $-0.8[-3.9,2.3]$ \\
\hline Tighe 2010 Wheat + Oats & 68 & $-2.5(7.1)$ & 31 & $-0.9(7.1)$ & $\because-1$ & $7.91 \%$ & $-1.64[-4.65,1.37]$ \\
\hline Subtotal $* \star \star$ & 207 & & 136 & & & $52.56 \%$ & $-2.4[-3.57,-1.23]$ \\
\hline \multicolumn{8}{|c|}{ Heterogeneity: $\mathrm{Tau}^{2}=0 ; \mathrm{Chi}^{2}=4.6, \mathrm{df}=3(\mathrm{P}=0.2) ; \mathrm{I}^{2}=34.85 \%$} \\
\hline \multicolumn{8}{|c|}{ Test for overall effect: $Z=4.03(P<0.0001)$} \\
\hline Total $\star \star \star ~$ & 397 & & 256 & & $\nabla$ & $100 \%$ & $-1.77[-2.62,-0.92]$ \\
\hline \multicolumn{8}{|c|}{ Heterogeneity: $\mathrm{Tau}^{2}=0 ; \mathrm{Chi}^{2}=9.69, \mathrm{df}=9(\mathrm{P}=0.38) ; \mathrm{I}^{2}=7.16 \%$} \\
\hline \multicolumn{8}{|c|}{ Test for overall effect: $Z=4.1(P<0.0001)$} \\
\hline Test for subgroup differe & $5, \mathrm{df}=$ & $P=0.13), I^{2}=5$ & & & & & \\
\hline
\end{tabular}

Favours fibre

Favours control

\section{Analysis 2.7. Comparison 2 Subgroup analyses, Outcome 7 Total cholesterol mmol/L change.}

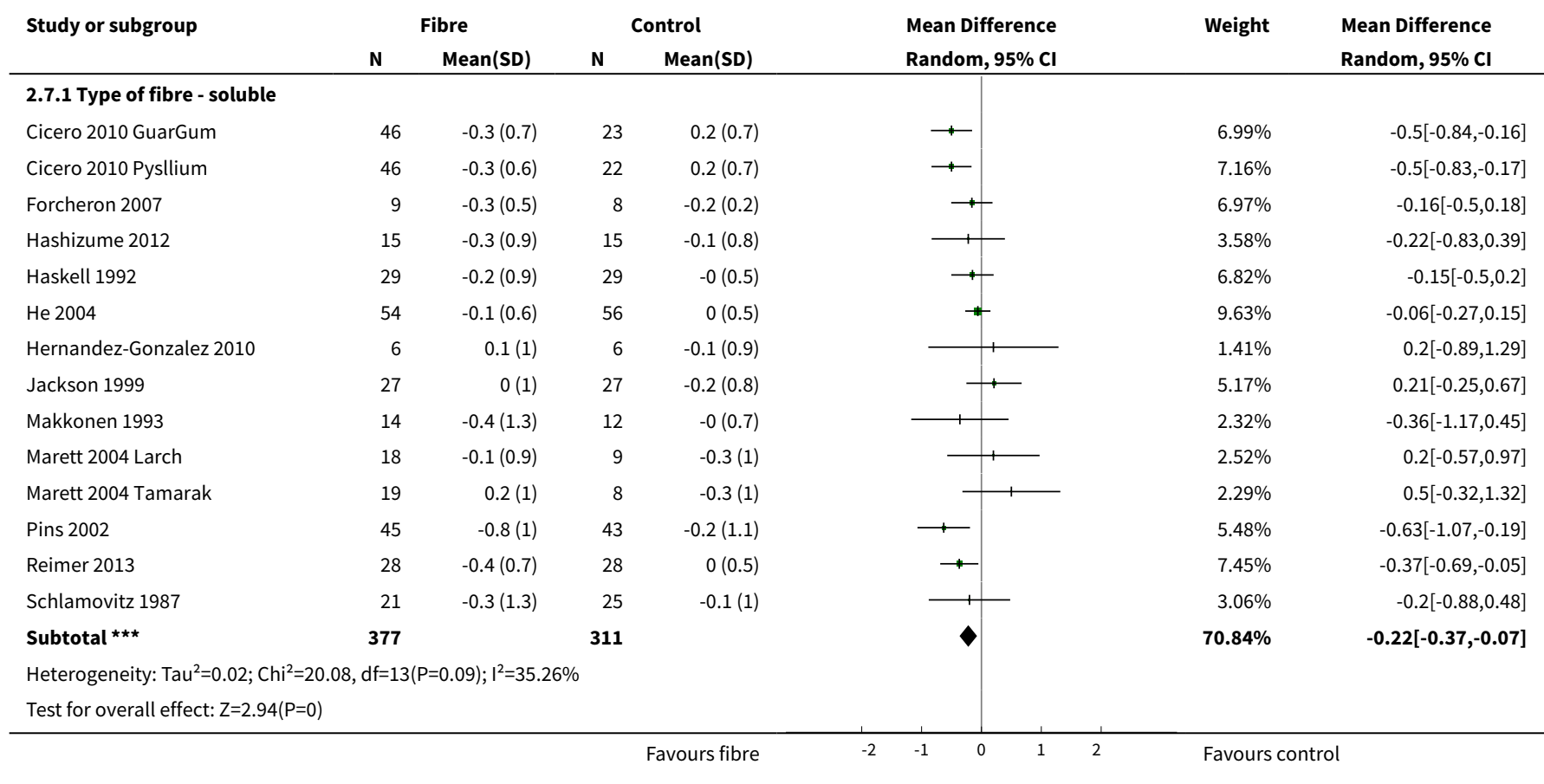

Dietary fibre for the primary prevention of cardiovascular disease (Review) 


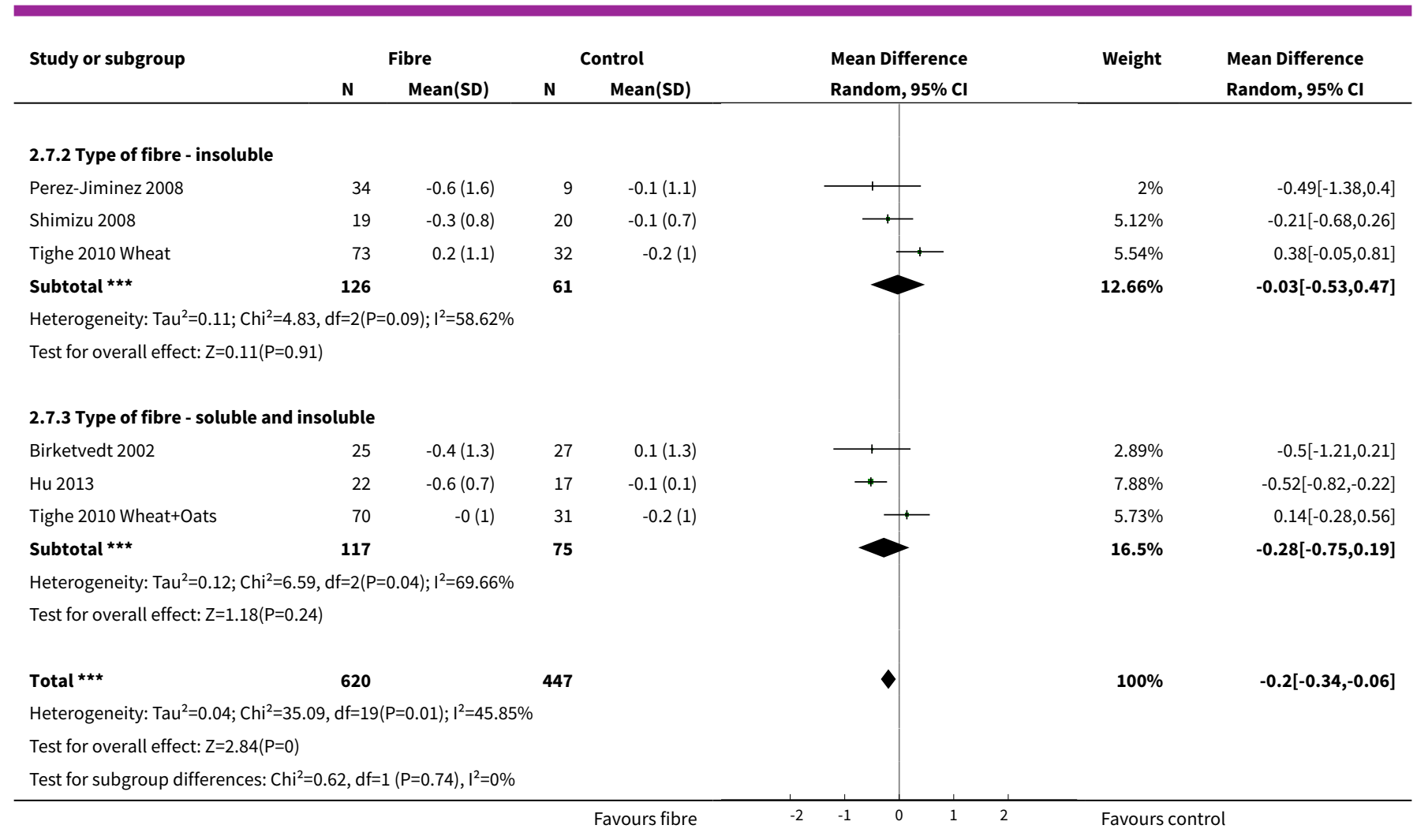

\section{Analysis 2.8. Comparison 2 Subgroup analyses, Outcome 8 HDL Cholesterol mmol/L change.}

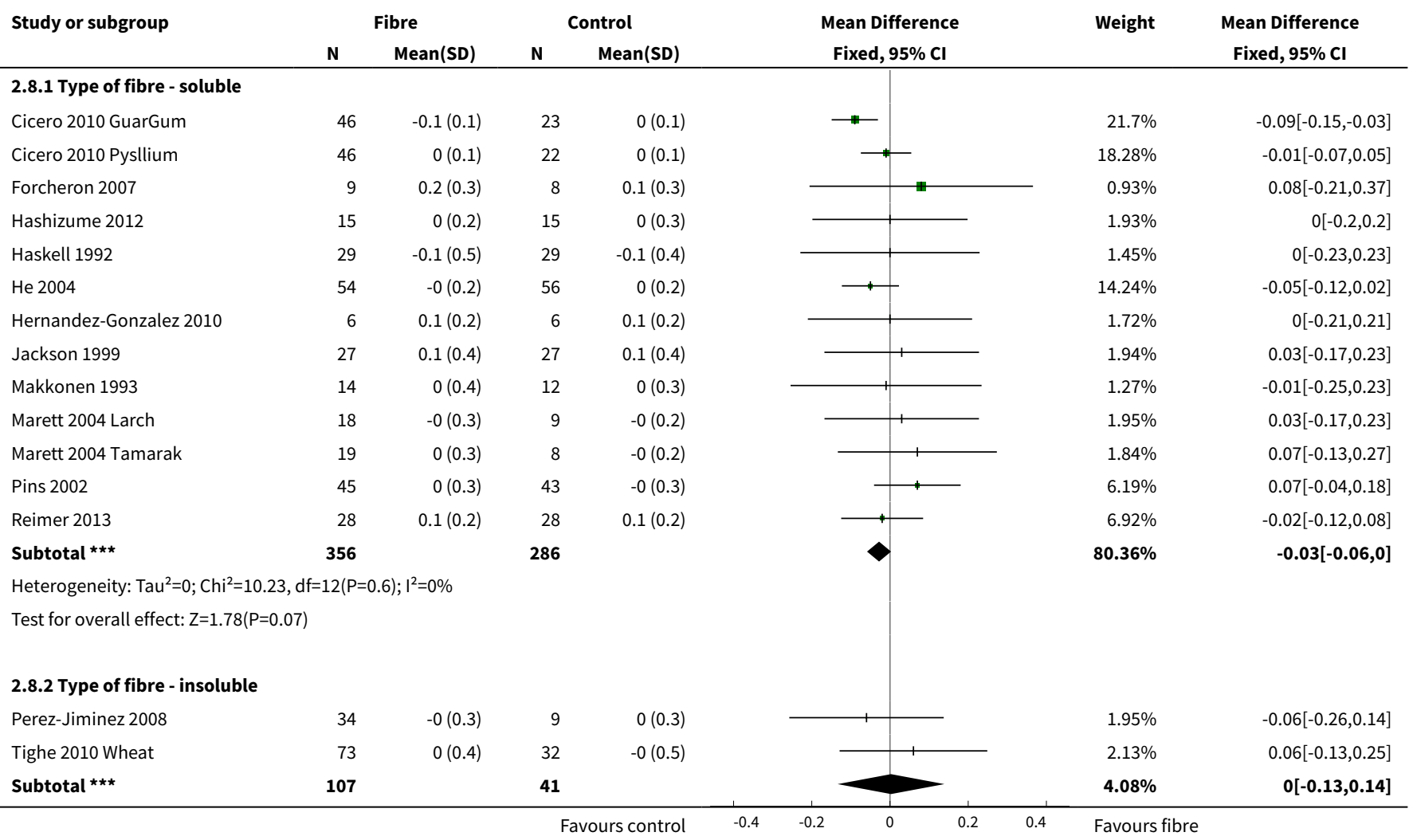




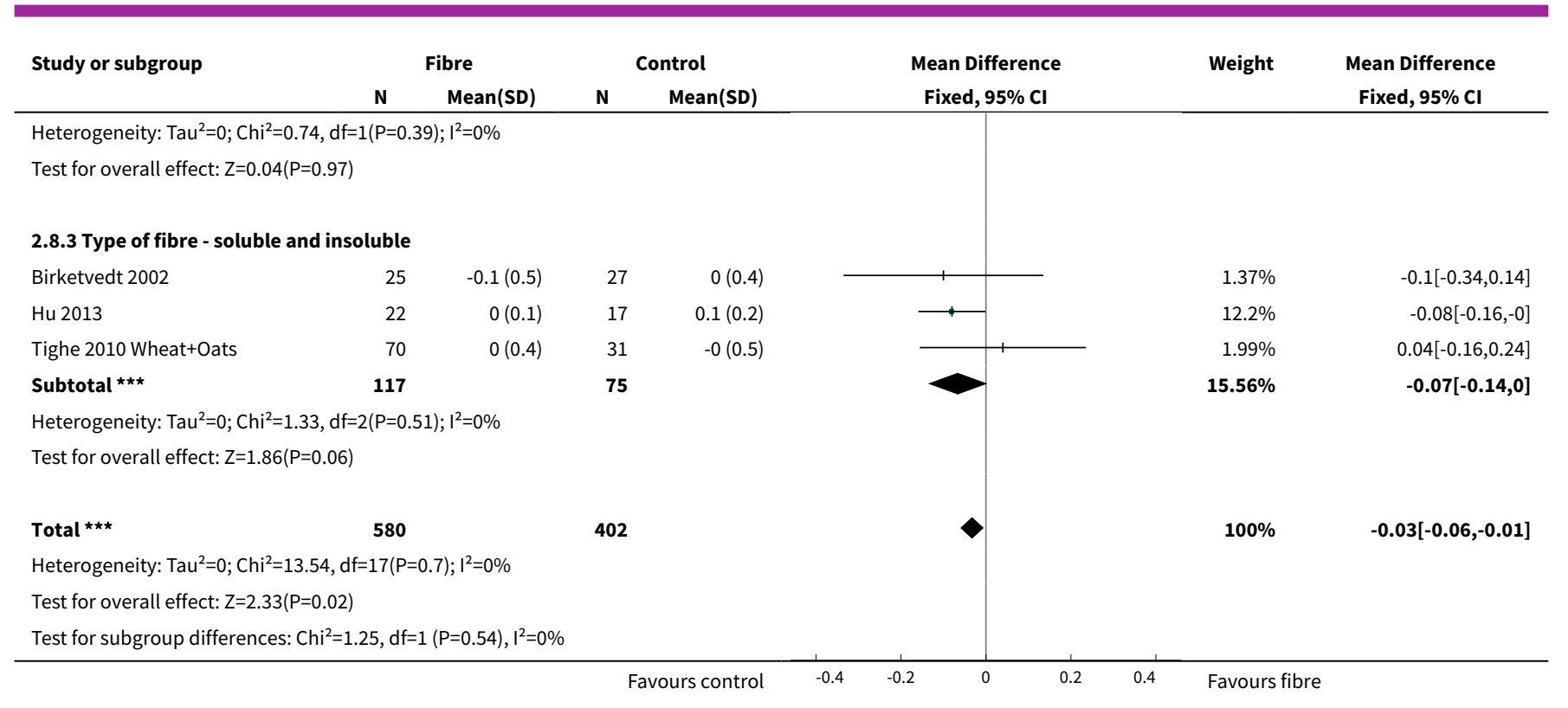

Analysis 2.9. Comparison 2 Subgroup analyses, Outcome 9 LDL Cholesterol mmol/L change.

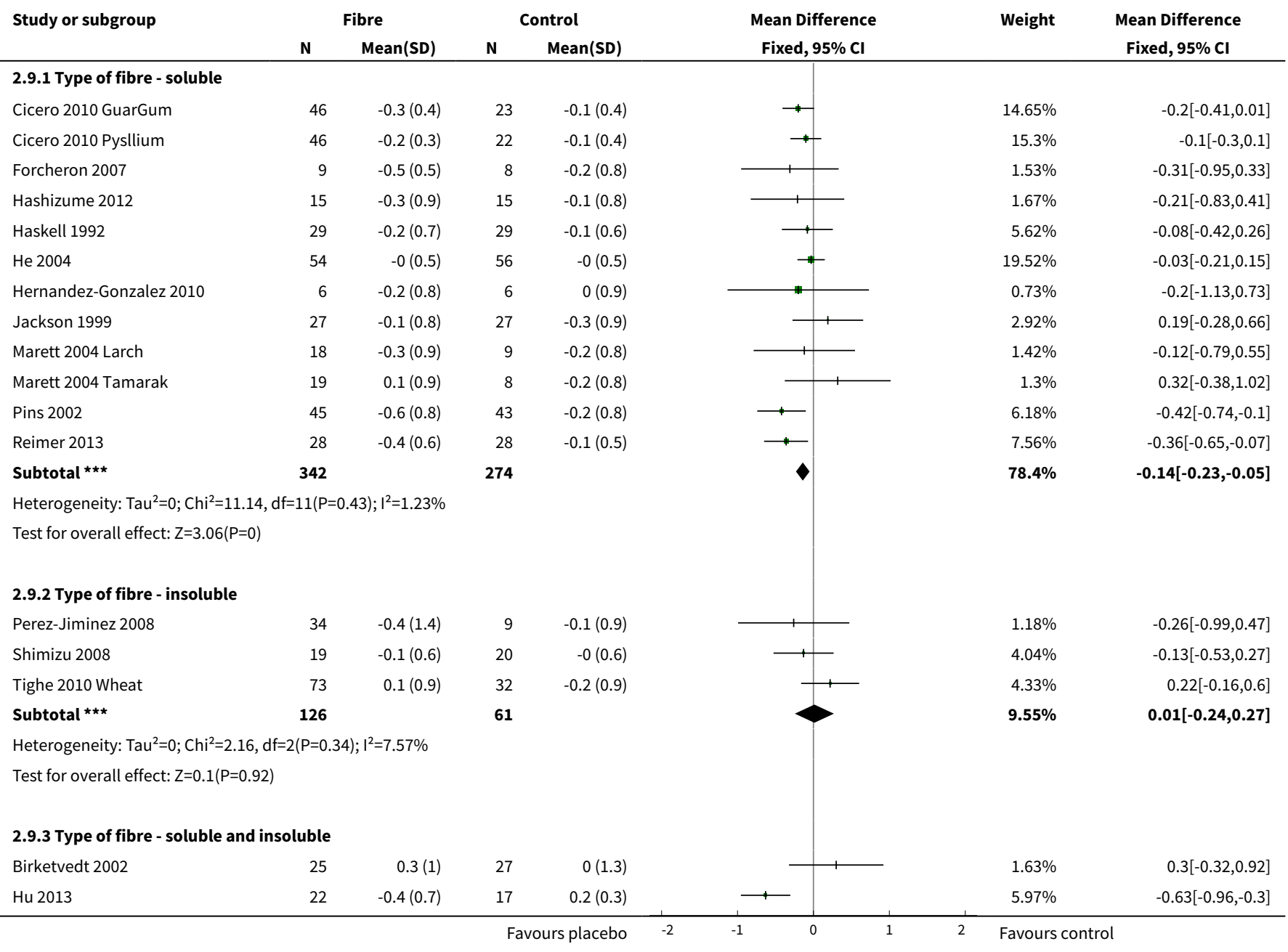




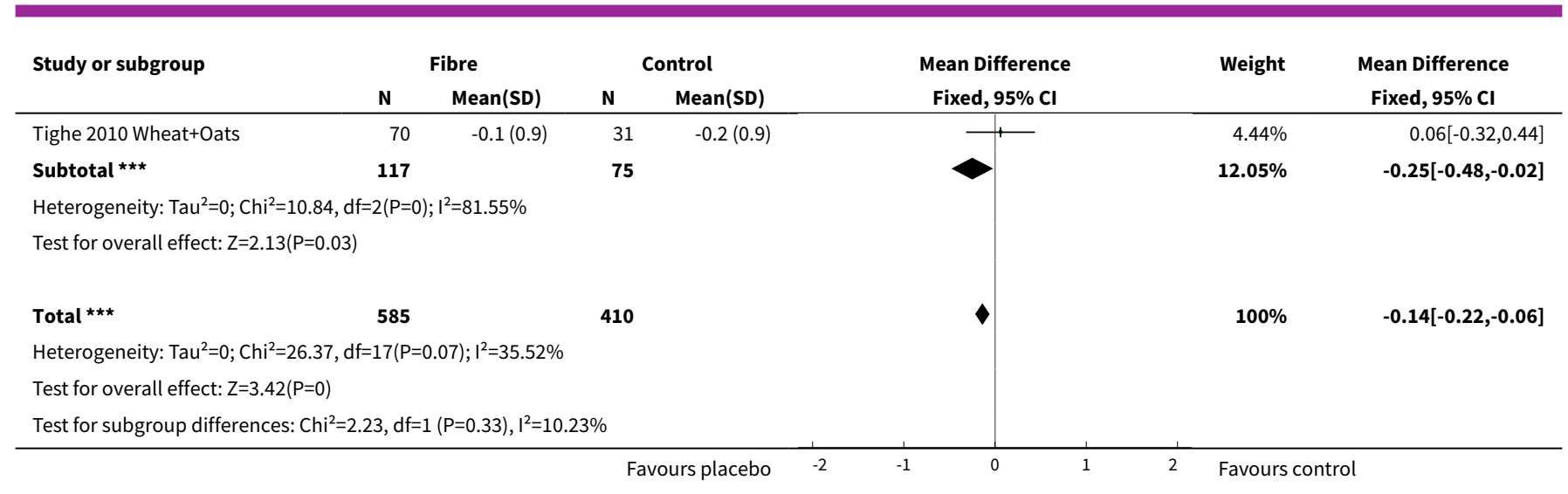

\section{Analysis 2.10. Comparison 2 Subgroup analyses, Outcome 10 Triglycerides $\mathrm{mmol} / \mathrm{L}$ change.}

\begin{tabular}{|c|c|c|c|c|c|c|c|}
\hline \multirow[t]{2}{*}{ Study or subgroup } & \multicolumn{2}{|c|}{ Fibre } & \multicolumn{2}{|c|}{ Control } & \multirow{2}{*}{$\begin{array}{c}\text { Mean Difference } \\
\text { Fixed, } 95 \% \mathrm{Cl}\end{array}$} & \multirow[t]{2}{*}{ Weight } & \multirow{2}{*}{$\begin{array}{c}\text { Mean Difference } \\
\text { Fixed, } 95 \% \mathrm{Cl}\end{array}$} \\
\hline & $\mathbf{N}$ & $\operatorname{Mean}(S D)$ & $\mathbf{N}$ & Mean(SD) & & & \\
\hline \multicolumn{8}{|c|}{ 2.10.1 Type of fibre - soluble } \\
\hline Cicero 2010 GuarGum & 46 & $-0.1(0.3)$ & 23 & $-0.1(0.4)$ & + & $6.54 \%$ & $0[-0.17,0.17]$ \\
\hline Cicero 2010 Pysllium & 46 & $-0.2(0.3)$ & 22 & $-0.1(0.4)$ & + & $6.32 \%$ & $-0.1[-0.27,0.07]$ \\
\hline Forcheron 2007 & 9 & $0.1(0.4)$ & 8 & $-0.1(0.4)$ & + & $1.23 \%$ & $0.2[-0.18,0.58]$ \\
\hline Hashizume 2012 & 15 & $-0.7(0.5)$ & 15 & $-0.1(0.5)$ & $\multimap$ & $1.41 \%$ & $-0.64[-1,-0.28]$ \\
\hline He 2004 & 54 & $-0(4)$ & 56 & $-0.5(0.6)$ & & $0.16 \%$ & $0.52[-0.55,1.59]$ \\
\hline Hernandez-Gonzalez 2010 & 6 & $-0.8(0.9)$ & 6 & $-0.3(0.5)$ & - & $0.26 \%$ & $-0.5[-1.33,0.33]$ \\
\hline Jackson 1999 & 27 & $-0(0.6)$ & 27 & $0.1(0.5)$ & - & $2.18 \%$ & $-0.12[-0.41,0.17]$ \\
\hline Makkonen 1993 & 14 & $-0(0.7)$ & 12 & $-0.3(0.7)$ & 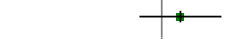 & $0.59 \%$ & $0.25[-0.3,0.8]$ \\
\hline Marett 2004 Larch & 18 & $-0(0.6)$ & 9 & $-0.2(0.8)$ & 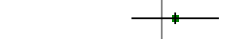 & $0.52 \%$ & $0.18[-0.4,0.76]$ \\
\hline Marett 2004 Tamarak & 19 & $0.2(0.5)$ & 8 & $-0.2(0.8)$ & * & $0.52 \%$ & $0.36[-0.23,0.95]$ \\
\hline Reimer 2013 & 28 & $0.1(0.7)$ & 28 & $0(0.4)$ & 1 & $2 \%$ & $0.05[-0.25,0.35]$ \\
\hline Subtotal $\star \star \star$ & 356 & & 286 & & 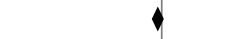 & $27.56 \%$ & $-0.05[-0.13,0.03]$ \\
\hline \multicolumn{8}{|c|}{ Heterogeneity: $\mathrm{Tau}^{2}=0 ; \mathrm{Chi}^{2}=19.45, \mathrm{df}=12(\mathrm{P}=0.08) ; \mathrm{I}^{2}=38.3 \%$} \\
\hline \multicolumn{8}{|c|}{ Test for overall effect: $\mathrm{Z}=1.28(\mathrm{P}=0.2)$} \\
\hline \multicolumn{8}{|c|}{ 2.10.2 Type of fibre - insoluble } \\
\hline Perez-Jiminez 2008 & 34 & $-0.2(0.8)$ & 9 & $0(0.2)$ & + & $1.96 \%$ & $-0.22[-0.52,0.08]$ \\
\hline Tighe 2010 Wheat & 73 & $-0(0.6)$ & 32 & $-0(0.8)$ & 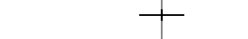 & $1.97 \%$ & $0[-0.3,0.3]$ \\
\hline Subtotal $\star \star \star$ & 107 & & 41 & & & $3.92 \%$ & $-0.11[-0.32,0.1]$ \\
\hline \multicolumn{8}{|c|}{ Heterogeneity: $\operatorname{Tau}^{2}=0 ; \mathrm{Chi}^{2}=1.02, \mathrm{df}=1(\mathrm{P}=0.31) ; \mathrm{I}^{2}=2 \%$} \\
\hline \multicolumn{8}{|c|}{ Test for overall effect: $Z=1.01(P=0.31)$} \\
\hline \multicolumn{8}{|c|}{ 2.10.3 Type of fibre - soluble and insoluble } \\
\hline Tighe 2010 Wheat+Oats & 70 & $0.1(0.6)$ & 31 & $-0(0.8)$ & + & $2.03 \%$ & $0.12[-0.18,0.42]$ \\
\hline Subtotal ${ }^{\star \star \star}$ & 117 & & 75 & & 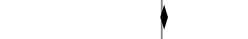 & $68.52 \%$ & $0.03[-0.02,0.08]$ \\
\hline \multicolumn{8}{|c|}{ Heterogeneity: Tau $^{2}=0 ; \mathrm{Chi}^{2}=0.44, \mathrm{df}=2(\mathrm{P}=0.8) ; \mathrm{I}^{2}=0 \%$} \\
\hline \multicolumn{8}{|c|}{ Test for overall effect: $Z=1.24(P=0.22)$} \\
\hline Total $\star \star \star$ & 580 & & 402 & & 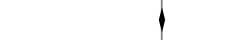 & $100 \%$ & $0[-0.04,0.05]$ \\
\hline
\end{tabular}




\begin{tabular}{|c|c|c|c|c|c|c|}
\hline \multirow[t]{2}{*}{ Study or subgroup } & Fibre & \multicolumn{2}{|c|}{ Control } & \multirow{2}{*}{$\begin{array}{c}\text { Mean Difference } \\
\text { Fixed, } 95 \% \mathrm{Cl}\end{array}$} & \multirow[t]{2}{*}{ Weight } & \multirow{2}{*}{$\begin{array}{c}\text { Mean Difference } \\
\text { Fixed, } 95 \% \mathrm{Cl}\end{array}$} \\
\hline & Mean(SD) & $\mathbf{N}$ & Mean(SD) & & & \\
\hline \multicolumn{7}{|c|}{ Heterogeneity: $\mathrm{Tau}^{2}=0 ; \mathrm{Chi}^{2}=25.06, \mathrm{df}=17(\mathrm{P}=0.09) ; \mathrm{I}^{2}=32.16 \%$} \\
\hline \multicolumn{7}{|c|}{ Test for overall effect: $Z=0.15(P=0.88)$} \\
\hline \multicolumn{7}{|c|}{ Test for subgroup differences: $\mathrm{Chi}^{2}=4.15, \mathrm{df}=1(\mathrm{P}=0.13), \mathrm{I}^{2}=51.85 \%$} \\
\hline
\end{tabular}

\section{Analysis 2.11. Comparison 2 Subgroup analyses, Outcome 11 Systolic blood pressure ( $\mathrm{mmHg}$ ) change.}

\begin{tabular}{lrrrr} 
Study or subgroup & \multicolumn{2}{c}{ Fibre } & \multicolumn{2}{c}{ Control } \\
& N & Mean(SD) & N & Mean(SD) \\
\hline 2.11.1 Type of fibre - soluble & & & & \\
Cicero 2010 GuarGum & 46 & $-3.4(3.9)$ & 23 & $-1(3.8)$ \\
Cicero 2010 Pysllium & 46 & $-5.2(3.9)$ & 22 & $-1(3.8)$ \\
He 2004 & 54 & $-3.4(7.3)$ & 56 & $-1.6(6.2)$ \\
Makkonen 1993 & 15 & $-3.1(20.2)$ & 13 & $-8.9(13.2)$ \\
Reimer 2013 & 28 & $-2.6(7.9)$ & 28 & $-6.4(10.6)$ \\
Schlamovitz 1987 & 21 & $-10(15.4)$ & 25 & $1(12.1)$ \\
Subtotal $\star \star \star$ & $\mathbf{2 1 0}$ & & $\mathbf{1 6 7}$ &
\end{tabular}

Heterogeneity: $\mathrm{Tau}^{2}=5.12 ; \mathrm{Chi}^{2}=15.42, \mathrm{df}=5(\mathrm{P}=0.01) ; \mathrm{I}^{2}=67.57 \%$

Test for overall effect: $\mathrm{Z}=1.74(\mathrm{P}=0.08)$

2.11.2 Type of fibre -insoluble

\begin{tabular}{|c|c|c|c|c|}
\hline Perez-Jiminez 2008 & 34 & $-8.5(21)$ & 9 & $-7.8(12.4)$ \\
\hline Tighe 2010 Wheat & 71 & $-4.9(11.7)$ & 32 & $-1.1(13)$ \\
\hline 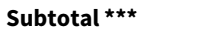 & 105 & & 41 & \\
\hline
\end{tabular}

$\begin{array}{lll}\text { Mean Difference } & \text { Weight } & \text { Mean Difference } \\ \text { Random, 95\% Cl } & \text { Random, 95\% Cl }\end{array}$

Heterogeneity: $\mathrm{Tau}^{2}=0 ; \mathrm{Chi}^{2}=0.26, \mathrm{df}=1(\mathrm{P}=0.61) ; \mathrm{I}^{2}=0 \%$

Test for overall effect: $Z=1.33(P=0.18)$

2.11.3 Type of fibre - soluble and insoluble

\begin{tabular}{|c|c|c|c|}
\hline Hu 2013 & 22 & $-1.2(2.5)$ & 17 \\
\hline Tighe 2010 Wheat+Oats & 68 & $-6.1(12.2)$ & 31 \\
\hline 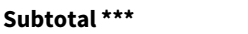 & 90 & & 48 \\
\hline
\end{tabular}

\begin{tabular}{|c|c|c|}
\hline+ & & $16.24 \%$ \\
\hline$\rightarrow$ & & $16.15 \%$ \\
\hline$\rightarrow$ & & $14.74 \%$ \\
\hline & . & $2.46 \%$ \\
\hline & & 年 \\
\hline & & $63.85 \%$ \\
\hline
\end{tabular}

$-2.4[-4.31,-0.49]$

$-4.2[-6.15,-2.25]$

$-1.8[-4.34,0.74]$

$5.82[-6.67,18.31]$

$3.8[-1.1,8.7]$

$-11[-19.12,-2.88]$

$-2.19[-4.66,0.28]$

Heterogeneity: $\mathrm{Tau}^{2}=16.45 ; \mathrm{Chi}^{2}=4.78, \mathrm{df}=1(\mathrm{P}=0.03) ; \mathrm{I}^{2}=79.08 \%$

Test for overall effect: $Z=0.4(P=0.69)$

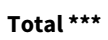

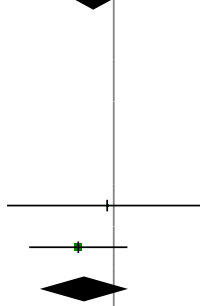

$3.2 \%$

$8.65 \%$

$\mathbf{1 1 . 8 4 \%}$

$-0.7[-11.42,10.02]$

$-3.79[-9.04,1.46]$

$-3.19[-7.91,1.52]$

Heterogeneity: $\mathrm{Tau}^{2}=6.14 ; \mathrm{Chi}^{2}=29.25, \mathrm{df}=9(\mathrm{P}=0) ; \mathrm{I}^{2}=69.23 \%$

Test for overall effect: $Z=1.79(P=0.07)$

Test for subgroup differences: $\mathrm{Chi}^{2}=0.25, \mathrm{df}=1(\mathrm{P}=0.88), \mathrm{I}^{2}=0 \%$

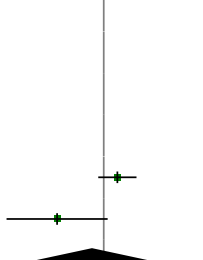

$15.93 \%$

$8.37 \%$

$24.31 \%$

$100 \%$

$-1.92[-4.02,0.19]$

Analysis 2.12. Comparison 2 Subgroup analyses, Outcome 12 Diastolic blood pressure (mmHg) change.

\begin{tabular}{|c|c|c|c|c|c|c|c|}
\hline \multirow{2}{*}{ Study or subgroup } & \multicolumn{2}{|c|}{ Fibre } & \multicolumn{2}{|c|}{ Control } & \multirow{2}{*}{$\begin{array}{c}\text { Mean Difference } \\
\text { Fixed, } 95 \% \mathrm{Cl} \\
\end{array}$} & \multirow[t]{2}{*}{ Weight } & \multirow{2}{*}{$\begin{array}{c}\text { Mean Difference } \\
\text { Fixed, } 95 \% \mathrm{Cl}\end{array}$} \\
\hline & $\mathbf{N}$ & Mean(SD) & $\mathbf{N}$ & Mean(SD) & & & \\
\hline \multicolumn{8}{|c|}{ 2.12.1 Type of fibre - soluble } \\
\hline Cicero 2010 GuarGum & 46 & $-1.8(3.6)$ & 23 & $-0.7(4)$ & $\rightarrow$ & $19.51 \%$ & $-1.1[-3.01,0.81]$ \\
\hline Cicero 2010 Pysllium & 46 & $-2.2(3.9)$ & 22 & $-0.7(4)$ & $\rightarrow$ & $17.9 \%$ & $-1.5[-3.5,0.5]$ \\
\hline
\end{tabular}




\begin{tabular}{|c|c|c|c|c|c|c|c|}
\hline \multirow[t]{2}{*}{ Study or subgroup } & \multicolumn{2}{|c|}{ Fibre } & \multicolumn{2}{|c|}{ Control } & \multirow{2}{*}{$\begin{array}{c}\text { Mean Difference } \\
\text { Fixed, } 95 \% \mathrm{Cl} \\
\end{array}$} & \multirow[t]{2}{*}{ Weight } & \multirow{2}{*}{$\begin{array}{c}\text { Mean Difference } \\
\text { Fixed, } 95 \% \mathrm{Cl} \\
\end{array}$} \\
\hline & $\mathbf{N}$ & $\operatorname{Mean}(\mathrm{SD})$ & $\mathbf{N}$ & Mean(SD) & & & \\
\hline He 2004 & 54 & $-2.2(7.9)$ & 56 & $-1.1(5)$ & +1 & $11.6 \%$ & $-1.1[-3.58,1.38]$ \\
\hline Makkonen 1993 & 15 & $-1.5(11)$ & 13 & $-1.1(7.4)$ & & $1.51 \%$ & $-0.36[-7.25,6.53]$ \\
\hline Reimer 2013 & 28 & $-2.2(5.8)$ & 28 & $-3.6(7.9)$ & + & $5.42 \%$ & $1.4[-2.23,5.03]$ \\
\hline Schlamovitz 1987 & 21 & $-5(9.6)$ & 25 & $-2(10.6)$ & - & $2.1 \%$ & $-3[-8.83,2.83]$ \\
\hline \multicolumn{8}{|c|}{ Heterogeneity: $\operatorname{Tau}^{2}=0 ; \mathrm{Chi}^{2}=2.42, \mathrm{df}=5(\mathrm{P}=0.79) ; \mathrm{I}^{2}=0 \%$} \\
\hline \multicolumn{8}{|c|}{ Test for overall effect: $Z=1.84(P=0.07)$} \\
\hline \multicolumn{8}{|c|}{ 2.12.2 Type of fibre -insoluble } \\
\hline Perez-Jiminez 2008 & 34 & $-3.8(11.9)$ & 9 & $-0.1(12.6)$ & & $0.86 \%$ & $-3.7[-12.83,5.43]$ \\
\hline Tighe 2010 Wheat & 71 & $-1.7(7.7)$ & 32 & $-0.9(7.1)$ & - & $7.74 \%$ & $-0.8[-3.84,2.24]$ \\
\hline \multicolumn{8}{|c|}{ Heterogeneity: $\operatorname{Tau}^{2}=0 ; \mathrm{Chi}^{2}=0.35, \mathrm{df}=1(\mathrm{P}=0.55) ; \mathrm{I}^{2}=0 \%$} \\
\hline \multicolumn{8}{|c|}{ Test for overall effect: $Z=0.74(P=0.46)$} \\
\hline \multicolumn{8}{|c|}{ 2.12.3 Type of fibre - soluble and insoluble } \\
\hline Hu 2013 & 22 & $-4.8(2.7)$ & 17 & $-1.1(2.6)$ & $\rightarrow$ & $25.49 \%$ & $-3.69[-5.36,-2.02]$ \\
\hline Tighe 2010 Wheat + Oats & 68 & $-2.5(7.1)$ & 31 & $-0.9(7.1)$ & . & $7.89 \%$ & $-1.64[-4.65,1.37]$ \\
\hline Subtotal $\star \star \star ~$ & 90 & & 48 & & & $33.37 \%$ & $-3.21[-4.67,-1.74]$ \\
\hline \multicolumn{8}{|c|}{ Heterogeneity: $\mathrm{Tau}^{2}=0 ; \mathrm{Chi}^{2}=1.36, \mathrm{df}=1(\mathrm{P}=0.24) ; \mathrm{I}^{2}=26.59 \%$} \\
\hline \multicolumn{8}{|c|}{ Test for overall effect: $Z=4.3(P<0.0001)$} \\
\hline Total $\star \star \star ~$ & 405 & & 256 & & 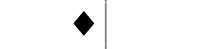 & $100 \%$ & $-1.77[-2.61,-0.92]$ \\
\hline \multicolumn{8}{|c|}{ Heterogeneity: $\mathrm{Tau}^{2}=0 ; \mathrm{Chi}^{2}=9.71, \mathrm{df}=9(\mathrm{P}=0.37) ; \mathrm{I}^{2}=7.32 \%$} \\
\hline \multicolumn{8}{|c|}{ Test for overall effect: $Z=4.1(P<0.0001)$} \\
\hline
\end{tabular}

\section{APPENDICES}

\section{Appendix 1. Search Strategy}

\section{Cochrane Library}

\#1MeSH descriptor: [Dietary Fiber] explode all trees

\#2roughage*

\#3prebiotic*

\#4carbohydrate near/2 polymer*

\#5((non-starch or nonstarch) near (poly-saccharide* or polysaccharide $\left.{ }^{\star}\right)$ )

\#6\#1 or \#2 or \#3 or \#4 or \#5

\#7MeSH descriptor: [Diet] this term only

\#8diet*

\#9consum*

$\# 10$ eat ${ }^{*}$

$\# 11$ food ${ }^{*}$

$\# 12$ nutri*

$\# 13 \# 7$ or \#8 or \#9 or \#10 or \#11 or \#12

\#14MeSH descriptor: [Chitin] explode all trees

\#15MeSH descriptor: [Cellulose] explode all trees

\#16chitin*

$\# 17$ lignin*

\#18hemicellulose ${ }^{\star}$

\#19hexosane* 
\#20pentosane*

\#21xanthan *

\#22MeSH descriptor: [Fructans] explode all trees

\#23fructan*

\#24inulin*

\#25polyuronide*

\#26MeSH descriptor: [Pectins] explode all trees

\#27pectin ${ }^{*}$

\#28MeSH descriptor: [Alginates] this term only

\#29alginate*

\#30alginic near/2 acid*

\#31MeSH descriptor: [Agar] this term only

\#32agar*

\#33MeSH descriptor: [Carrageenan] this term only

\#34carrageen ${ }^{*}$

\#35MeSH descriptor: [Raffinose] this term only

\#36raffinose*

\#37MeSH descriptor: [Xylose] this term only

\#38xylose*

\#39polydextrose*

\#40MeSH descriptor: [Lactulose] this term only

\#41lactulose*

\#42cellulose ${ }^{\star}$

\#43fibre* or fiber* or high-fibre* or high-fiber *

$\# 44 \# 14$ or \#15 or \#16 or \#17 or \#18 or \#19 or \#20 or \#21 or \#22 or \#23 or \#24 or \#25 or \#26 or \#27 or \#28 or \#29 or \#30 or \#31 or \#32 or \#33 or \#34 or \#35 or \#36 or \#37 or \#38 or \#39 or \#40 or \#41 or \#42 or \#43

\#45\#13 and \#44

\#46\#6 or \#45

\#47MeSH descriptor: [Cardiovascular Diseases] explode all trees

\#48cardio*

\#49cardia*

\#50heart*

\#51coronary*

\#52angina*

\#53ventric*

\#54myocard*

\#55 pericard*

\#56isch?em*

\#57emboli*

\#58arrhythmi*

\#59thrombo*

\#60atrial next fibrillat*

\#61tachycardi ${ }^{\star}$

\#62endocardi *

\#63(sick next sinus)

\#64MeSH descriptor: [Stroke] explode all trees

$\# 65$ (stroke or stokes)

\#66cerebrovasc*

\#67cerebral next vascular

\#68apoplexy

\#69(brain near/2 accident ${ }^{\star}$ )

\#70((brain* or cerebral or lacunar) near/2 infarct ${ }^{\star}$ )

$\# 71 \mathrm{MeSH}$ descriptor: [Hypertension] explode all trees

\#72hypertensi ${ }^{\star}$

\#73(peripheral next arter* next disease ${ }^{\star}$ )

\#74((high or increased or elevated) near/2 blood pressure)

\#75MeSH descriptor: [Hyperlipidemias] explode all trees

\#76hyperlipid*

\#77hyperlip?emia*

\#78hypercholesterol ${ }^{*}$

\#79hypercholester?emia*

\#80hyperlipoprotein?emia*

Dietary fibre for the primary prevention of cardiovascular disease (Review)

Copyright @ 2016 The Cochrane Collaboration. Published by John Wiley \& Sons, Ltd. 
\#81hypertriglycerid?emia*

\#82MeSH descriptor: [Arteriosclerosis] explode all trees

\#83MeSH descriptor: [Cholesterol] explode all trees

\#84cholesterol

\#85"coronary risk factor ${ }^{\star "}$

\#86MeSH descriptor: [Blood Pressure] this term only

\#87"blood pressure"

$\# 88 \# 47$ or \#48 or \#49 or \#50 or \#51 or \#52 or \#53 or \#54 or \#55 or \#56 or \#57 or \#58 or \#59 or \#60 or \#61 or \#62 or \#63 or \#64 or \#65 or \#66 or $\# 67$ or \#68 or \#69 or \#70 or \#71 or \#72 or \#73 or \#74 or \#75 or \#76 or \#77 or \#78 or \#79 or \#80 or \#81 or \#82 or \#83 or \#84 or \#85 or \#86 or \#87 $\# 89 \# 46$ and \#88

\section{MEDLINE OVID}

1. exp Dietary Fiber/

2. roughage*.tw.

3. prebiotic*.tw.

4. (carbohydrate adj2 polymer $\left.{ }^{\star}\right)$.tw.

5. ((non-starch or nonstarch) adj (poly-saccharide* or polysaccharide $\left.{ }^{\star}\right)$.tw.

6. or/1-5

7. Diet/

8. diet $^{\star}$.tw.

9. consum*.tw.

10. eat*.tw.

11. food ${ }^{*}$.tw.

12. nutri*. tw.

13. or/7-12

14. exp Chitin/

15. exp Cellulose/

16. chitin ${ }^{\star} . t w$.

17. lignin*.tw.

18. hemicellulose ${ }^{\star} . t w$.

19. hexosane $e^{\star} . t w$.

20. pentosane $e^{\star}$. tw.

21. xanthan*.tw.

22. exp Fructans/

23. fructan ${ }^{\star}$. tw.

24. inulin*.tw.

25. polyuronide ${ }^{\star}$.tw.

26. Pectins/

27. pectin*.tw.

28. Alginates/

29. alginate ${ }^{\star}$. tw.

30. (alginic adj2 acid*).tw.

31. Agar/

32. agar ${ }^{\star} . t w$.

33. Carrageenan/

34. carrageen*.tw.

35. Raffinose/

36. raffinose ${ }^{\star} . t w$.

37. Xylose/

38. xylose .tw. $^{-}$

39. polydextrose ${ }^{\star}$.tw.

40. Lactulose/

41. lactulose ${ }^{\star}$. tw.

42. cellulose ${ }^{\star}$.tw.

43. (fibre* or fiber ${ }^{\star}$ or high-fibre* or high-fiber $\left.{ }^{\star}\right)$.tw.

44. or/14-43

45. 13 and 44

46.6 or 45

47. exp Cardiovascular Diseases/

48. cardio*.tw.

49. cardia* .tw. 
50. heart*.tw.

51. coronary ${ }^{\star}$.tw.

52. angina*.tw.

53. ventric ${ }^{\star} . t w$.

54. myocard*.tw.

55. pericard ${ }^{\star}$. tw.

56. isch?em ${ }^{\star}$.tw.

57. emboli*.tw.

58. arrhythmi*.tw.

59. thrombo*.tw.

60. atrial fibrillat*.tw.

61. tachycardi*.tw.

62. endocardi*.tw.

63. (sick adj sinus).tw.

64. exp Stroke/

65. (stroke or stokes).tw.

66. cerebrovasc ${ }^{\star}$.tw.

67. cerebral vascular.tw.

68. apoplexy.tw.

69. (brain adj2 accident ${ }^{\star}$ ).tw.

70. ((brain* or cerebral or lacunar) adj2 infarct $\left.{ }^{\star}\right)$.tw.

71. exp Hypertension/

72. hypertensi ${ }^{*}$.tw.

73. peripheral arter ${ }^{\star}$ disease ${ }^{\star} . t w$.

74. ((high or increased or elevated) adj2 blood pressure).tw.

75. exp Hyperlipidemias/

76. hyperlipid*.tw.

77. hyperlip?emia*.tw.

78. hypercholesterol*.tw.

79. hypercholester?emia*.tw.

80. hyperlipoprotein?emia*.tw.

81. hypertriglycerid?emia*.tw.

82. exp Arteriosclerosis/

83. exp Cholesterol/

84. cholesterol.tw.

85. "coronary risk factor* ".tw.

86. Blood Pressure/

87. blood pressure.tw.

88. or/47-87

89.46 and 88

90. randomized controlled trial.pt.

91. controlled clinical trial.pt.

92. randomized.ab.

93. placebo.ab.

94. drug therapy.fs.

95. randomly.ab.

96. trial.ab.

97. groups.ab.

98.90 or 91 or 92 or 93 or 94 or 95 or 96 or 97

99. exp animals/ not humans.sh.

100. 98 not 99

101. 89 and 100

\section{EMBASE OVID}

1. dietary fiber/

2. prebiotic agent/

3. roughage ${ }^{\star}$.tw.

4. prebiotic ${ }^{\star}$. tw.

5. (carbohydrate adj2 polymer ${ }^{\star}$.tw.

6. ((non-starch or nonstarch) adj (poly-saccharide* or polysaccharide $)$ ).tw.

7. high fiber diet/ 
8. or/1-7

9. diet/

10. diet ${ }^{\star}$. tw.

11. consum ${ }^{\star} . \mathrm{tw}$.

12. eat ${ }^{\star}$. tw.

13. food ${ }^{*}$.tw.

14. nutri*.tw.

15. or/9-14

16. chitin/

17. chitosan/

18. cellulose/

19. lignin/

20. chitin ${ }^{\star}$. tw.

21. lignin ${ }^{\star}$.tw.

22. hemicellulose ${ }^{\star}$. tw.

23. hexosane ${ }^{\star}$.tw.

24. pentosane ${ }^{\star}$.tw.

25. xanthan*.tw.

26. xanthan/

27. fructan/

28. inulin/

29. fructan ${ }^{\star}$.tw.

30. inulin*.tw.

31. polyuronide ${ }^{\star}$.tw.

32. pectin/

33. pectin ${ }^{\star}$. tw.

34. alginic acid/

35. alginate ${ }^{\star}$. tw.

36. (alginic adj2 acid $\left.{ }^{\star}\right)$.tw.

37. agar

38. agar*.tw.

39. carrageenan/

40. carrageen ${ }^{\star}$.tw.

41. raffinose/

42. raffinose ${ }^{\star}$.tw.

43. xylose/

44. xylose $e^{\star}$.tw.

45. polydextrose ${ }^{\star}$. tw.

46. lactulose/

47. lactulose ${ }^{\star}$. tw.

48. cellulose $e^{\star} . t w$.

49. (fibre* or fiber ${ }^{\star}$ or high-fibre ${ }^{\star}$ or high-fiber $\left.{ }^{\star}\right)$.tw.

50. or/16-49

51.15 and 50

52.8 or 51

53. exp cardiovascular disease/

54. cardio*.tw.

55. cardia*.tw.

56. heart*..tw.

57. coronary ${ }^{\star}$.tw.

58. angina ${ }^{\star}$. tw.

59. ventric ${ }^{\star}$. tw.

60. myocard*.tw.

61. pericard*.tw.

62. isch?em*.tw.

63. emboli*.tw.

64. arrhythmi*.tw.

65. thrombo*.tw.

66. atrial fibrillat*.tw.

67. tachycardi*.tw.

68. endocardi ${ }^{\star}$.tw.

69. (sick adj sinus).tw.

Dietary fibre for the primary prevention of cardiovascular disease (Review) 
70. exp cerebrovascular disease/

71. (stroke or stokes).tw.

72. cerebrovasc ${ }^{\star}$. tw.

73. cerebral vascular.tw.

74. apoplexy.tw.

75. (brain adj2 accident ${ }^{\star}$ ).tw.

76. ((brain ${ }^{\star}$ or cerebral or lacunar) adj2 infarct $\left.{ }^{\star}\right)$.tw.

77. exp hypertension/

78. hypertensi ${ }^{\star}$. tw.

79. peripheral arter ${ }^{\star}$ disease ${ }^{\star}$. tw.

80. ((high or increased or elevated) adj2 blood pressure).tw.

81. exp hyperlipidemia/

82. hyperlipid*.tw.

83. hyperlip?emia*.tw.

84. hypercholesterol ${ }^{\star}$. tw.

85. hypercholester?emia*.tw.

86. hyperlipoprotein?emia*.tw.

87. hypertriglycerid?emia*.tw.

88. exp Arteriosclerosis/

89. exp Cholesterol/

90. cholesterol.tw.

91. "coronary risk factor*".tw.

92. Blood Pressure/

93. blood pressure.tw.

94. or/53-93

95.52 and 94

96. random\$.tw.

97. factorial\$.tw.

98. crossover\$.tw.

99. cross over $\$$.tw.

100. cross-over\$.tw.

101. placebo\$.tw.

102. (doubl\$ adj blind\$).tw.

103. (singl\$ adj blind\$).tw.

104. assign\$.tw.

105. allocat\$.tw.

106. volunteer\$.tw.

107. crossover procedure/

108. double blind procedure/

109. randomized controlled trial/

110 . single blind procedure/

111.96 or 97 or 98 or 99 or 100 or 101 or 102 or 103 or 104 or 105 or 106 or 107 or 108 or 109 or 110

112. (animal/ or nonhuman/) not human/

113. 111 not 112

114. 95 and 113

115. limit 114 to embase

\section{Web of Science}

\# 16 \#15 AND \#14

\# 15 TS=(random ${ }^{\star}$ or blind ${ }^{\star}$ or allocat ${ }^{\star}$ or assign ${ }^{\star}$ or trial* ${ }^{\star}$ or placebo* or crossover ${ }^{\star}$ or cross-over $\left.^{\star}\right)$

\# 14 \#13 AND \#12

\# 13 \#10 OR \#9 OR \#8 OR \#7 OR \#6 OR \#5 OR \#4

\# 12 \#11 OR \#1

\# 11 \#3 AND \#2

\# 10 TS=(hyperlipid* OR hyperlip?emia* OR hypercholesterol* OR hypercholester?emia* OR hyperlipoprotein?emia* OR hypertriglycerid? emia*)

\# 9 TS=("high blood pressure")

\# $8 \mathrm{TS}=\left(\right.$ hypertensi* OR "peripheral arter* disease $\left.^{\star} "\right)$

\# 7 TS=(stroke OR stokes OR cerebrovasc* OR cerebral OR apoplexy OR (brain SAME accident ${ }^{\star}$ ) OR (brain SAME infarct $\left.{ }^{\star}\right)$ )

\# 6 TS=("atrial fibrillat*" OR tachycardi* OR endocardi*)

\# 5 TS=(pericard* OR isch?em OR emboli* OR arrhythmi ${ }^{\star}$ OR thrombo*) 
\# 4 TS=(cardio* OR cardia* OR heart* OR coronary ${ }^{\star}$ OR angina* OR ventric* OR myocard ${ }^{\star}$ )

\# 3 TS=(chitin* or lignin* or hemicellulose* or hexosane* or pentosane ${ }^{\star}$ or xanthan ${ }^{\star}$ or fructan* or inulin* or polyuronide* or pectin* or

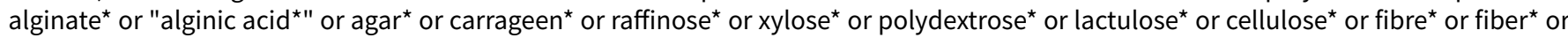
high-fibre* or high-fiber $\left.{ }^{\star}\right)$

\# 2 TS=(diet ${ }^{\star}$ or consum ${ }^{\star}$ or eat ${ }^{\star}$ or food ${ }^{\star}$ or nutri $\left.{ }^{\star}\right)$

\# 1 TS=("dietary fiber" or "dietary fibre" or roughage* or prebiotic* or "carbohydrate polymer*" or non-starch or "non starch" or polysaccharide* or polysaccharide*)

\section{WHAT'S NEW}

\begin{tabular}{lll}
\hline Date & Event & Description \\
\hline 5 February 2016 & Amended & $\begin{array}{l}\text { Typo corrected in total cholesterol data and text updated to re- } \\
\text { flect change }\end{array}$ \\
\hline
\end{tabular}

\section{CONTRIBUTIONS OF AUTHORS}

All authors contributed to protocol development. The Trials Search Co-ordinator of Cochrane Heart ran the searches. LH, MM, and KR screened titles and abstracts and assessed studies for formal inclusion and exclusion. LH, MM, EL and JC abstracted data and assessed methodological rigour. Analyses were conducted by EL and checked by JC and KR. LH wrote the first draft of the results which was updated by $E L$ and $K R$, and $K R$ wrote the remaining sections.

\section{DECLARATIONS OF INTEREST}

LH - None

MM - My work in the pharmaceutical industry as a Regulatory Affairs Consultant is not related in any way to this review. I was not involved in development, design or any review of efficacy of drug products. My work is based only in chemistry manufacturing and controls to ensure quality of established drug products for license changes.
EL - None
JC - None
KR - None

\section{SOURCES OF SUPPORT}

\section{Internal sources}

- Warwick Medical School, University of Warwick, UK.

\section{External sources}

- National Institute for Health Research Cochrane Programme Grant, UK.

- Karen Rees is also supported by the National Institute for Health Research Collaboration for Leadership in Applied Health Research and Care West Midlands at University Hospitals Birmingham NHS Foundation Trust, UK.

\section{DIFFERENCES BETWEEN PROTOCOL AND REVIEW}

We planned to search Google Scholar, Open Grey, conduct a citation search and contact experts. There was insufficient time and resources to do this.

We excluded participants with type 2 diabetes. Whilst this is a major risk factor for CVD, interventions for the treatment and management of type 2 diabetes are covered by reviews registered with the Cochrane Metabolic and Endocrine Disorders Group.

We excluded trials focused on weight loss in order to avoid confounding.

We did not use clinical endpoints in subgroup analyses as these were not reported in included trials. 


\section{N D EX TERMS}

\section{Medical Subject Headings (MeSH)}

Cardiovascular Diseases [blood] [*prevention \& control]; Cholesterol [blood]; Cholesterol, HDL [blood]; Cholesterol, LDL [blood]; Dietary Fiber [ ${ }^{\star}$ therapeutic use]; Primary Prevention [ ${ }^{\star}$ methods]; Randomized Controlled Trials as Topic; Triglycerides [blood]

\section{MeSH check words}

Adult; Humans 